\title{
Unraveling the Synergy of Chemical Hydroxylation and Physical Heterointerface on Improving Hydrogen Evolution Kinetics
}

Yang Liu ${ }^{a, b \dagger}$, Xinghui Liu ${ }^{a, b \dagger}$, Xiaoshan Wang ${ }^{e}$, Hui Ning ${ }^{e}$, Taehun Yanga, ${ }^{a, b}$, Jianmin $Y_{u^{a, b}}$, Ashwani Kumar ${ }^{a, b}$, Yongguang Luo ${ }^{a, b}$, Hongdan Wang ${ }^{a, b}$, Lingling Wang ${ }^{a}$, Jinsun Lee ${ }^{a, b}$, Amol R. Jadhav ${ }^{a}$, Han Hu ${ }^{e}$, Mingbo Wu , Min Gyu Kimf, Hyoyoung Lee $e^{a, b, c, d^{* *}}$

${ }^{a}$ Center for Integrated Nanostructure Physics, Institute for Basic Science (IBS), Sungkyunkwan University, Suwon, 16419, Republic of Korea

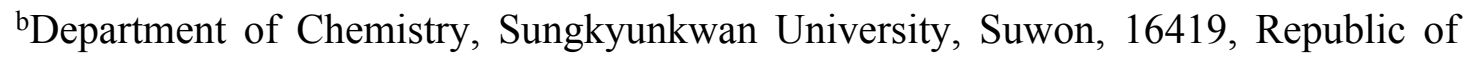
Korea

${ }^{\mathrm{c}}$ Creative Research Institute, Sungkyunkwan University, Suwon, 16419, Republic of Korea

${ }^{d}$ Department of Biophysics, Sungkyunkwan University, Suwon, 16419, Republic of Korea

eState Key Laboratory of Heavy Oil Processing, Institute of New Energy, College of Chemical Engineering, China University of Petroleum (East China), China

fBeamline Research Division, Pohang Accelerator Laboratory (PAL), Pohang University of Science and Technology, Pohang 37673, Republic of Korea

$\uparrow$ These authors contributed equally to this work

*(Hyoyoung Lee_Corresponding_Author). e-mail: hyoyoung@skku.edu

Keywords: Transition metal oxides, hydroxylation, water dissociation, heterointerface, hydrogen spillover, improved HER kinetics 


\section{Experimental Section}

Material characterizations. The morphology of the samples was investigated by using a JSM 7401F (JEOL Ltd., Tokyo, Japan) scanning electron microscope (SEM) operated at $3.0 \mathrm{kV}$. High-resolution TEM (HRTEM) images were acquired using a JEOL ARM2100F field-emission transmission electron microscope operated at $200 \mathrm{kV}$ accelerating voltage. X-ray photoelectron spectroscopy (XPS) was performed using a VG Microtech ESCA 2000 equipped with a monochromic Al X-ray source $(97.9 \mathrm{~W}, 93.9 \mathrm{eV})$. X-ray diffraction (XRD) patterns were acquired using a Rigaku Ultima IV, using the substrates directly. Fourier transform infrared spectra (FT-IR) of powdered samples were recorded using a Bruker Vertex 70. Water contact angle (WCA) and captive bubble method (CBM) measurements were acquired by using a Phoenix 300 Touch Automatic Contact Angle Analyzer operated at room temperature. Electron paramagnetic resonance (EPR; X-band CW-EPR, QM09, RT, $2.97 \mathrm{~mW}, 9.64 \mathrm{GHz}$ microwave frequency, $100 \mathrm{KHz}$ modulation frequency) measurements were obtained from the Korea Basic Science Institute in Seoul, Korea.

X-ray absorption spectroscopy was conducted at the BL14W1 beamline of the Beijing Synchrotron Radiation Facility. The storage ring was operated at $2.5 \mathrm{GeV}$ with $250 \mathrm{~mA}$ maximum current. Ni K-edge XAFS measurements were performed in fluorescence mode using a Lytle detector. All samples were as-prepared self-supported substrates of surface area $1 \mathrm{~cm}^{2}$. The acquired XAFS data were analyzed by using Athena and Artemis software according to standard analysis processes. The spectra were calibrated, averaged, pre-edge background subtracted, and post-edge normalized using the Athena program in the IFEFFIT software package. Fourier transformation of EXAFS oscillations from $\mathrm{k}$ space to $\mathrm{R}$ space was carried out to obtain a radial distribution function. All data fitting was carried out by using the Artemis software.

The in-situ X-ray absorption spectroscopy (XAS) measurements were performed at the BL10C beamline of the Pohang Light Source (PLS-II, Korea) under an operation mode of $3.0 \mathrm{G} \mathrm{eV}$ with a ring current of $250 \mathrm{~mA}$. The $\mathrm{HO}_{\mathrm{M}}-\mathrm{NiO} / \mathrm{Cu}$ was directly used as the working electrode during the measurements. In the homemade cell, electrochemistry was performed using a $\mathrm{Ag} / \mathrm{AgCl}$ reference electrode, a graphite rod counter electrode, and Ar-saturated $1 \mathrm{M} \mathrm{KOH}$ as the electrolyte, and kept the argon flow in the measurement process. The X-ray absorption fine structure (XAFS) spectra at Ni k-edge were recorded by fluorescence mode. All of XAFS data were recorded during one period of beam time.

Electrochemical measurements. Electrochemical measurements were performed in a standard three-electrode system (CHI 760E, USA) comprising the HO-NiO/Cu samples $\left(1 \mathrm{~cm}^{2}\right)$, a graphite rod $(\mathrm{d}=0.5 \mathrm{~cm})$, and saturated $\mathrm{Ag} / \mathrm{AgCl}(3 \mathrm{M} \mathrm{KCl})$ respectively as the working, counter, and reference electrodes. All potentials reported herein were referenced to a reversible hydrogen electrode (RHE) via the Nernst equation (eq. (1); based on RHE calibration; see Supplementary Fig. S1). Linear sweep voltammetry 
curves were recorded at the scan rate of $5 \mathrm{mV} / \mathrm{s}$ in $1 \mathrm{M} \mathrm{KOH}(\mathrm{pH}=13.6)$. The converted potential vs. RHE was calculated as follows (Supplementary Fig. S43):

$$
\mathrm{E}_{\mathrm{RHE}}=\mathrm{E}_{\mathrm{Ag} / \mathrm{AgCl}}+0.059 \mathrm{pH}+\mathrm{E}^{0}{ }_{\mathrm{Ag} / \mathrm{AgCl}},
$$

where $\mathrm{E}_{\mathrm{RHE}}$ is the converted potential vs. RHE, $\mathrm{E}_{\mathrm{Ag} / \mathrm{AgCl}}$ is the potential experimentally measured against the $\mathrm{Ag} / \mathrm{AgCl}$ reference electrode and $\mathrm{E}^{0} \mathrm{Ag} / \mathrm{AgCl}$ is the standard potential of $\mathrm{Ag} / \mathrm{AgCl}$ at $25^{\circ} \mathrm{C}(0.197 \mathrm{~V})$.

To prepare $\mathrm{Pt} / \mathrm{C}$ and $\mathrm{RuO}_{2}$ electrodes as control samples, first, catalyst ink was prepared by suspending $5 \mathrm{mg}$ of catalyst powder in a $1 \mathrm{~mL}$ solution consisting of 500 $\mu \mathrm{L}$ of $5 \mathrm{wt} \%$ Nafion (117 solution, Aldrich), $250 \mu \mathrm{L}$ of ethanol, and $710 \mu \mathrm{L}$ of distilled water. Then ink was drop-cast onto the $\mathrm{CF}$ to yield a mass density equivalent to that of $\mathrm{HO}-\mathrm{NiO}$ on $\mathrm{Cu}\left(1.8 \mathrm{mg} \mathrm{cm}^{-2}\right)$.

TOF values are calculated according to Equation for HER,

$$
\mathrm{TOF}=\frac{\mathrm{J} \times \mathrm{A}}{2 \times F \times n}
$$

Here, $\mathrm{J}$ is the current density $\left(\mathrm{mA} \mathrm{cm}^{-2}\right)$ at a given overpotential, $\mathrm{A}$ is the surface of the electrode, $\mathrm{n}$ is the mole number of metal atoms on the electrode, and $\mathrm{F}$ is the Faraday constant $\left(96485.3 \mathrm{C} \mathrm{mol}^{-1}\right)$. In the calculations, active-metal atoms are assumed to be catalytically active. However, the calculated TOF represents a lower limit because a fraction of metal sites might not contribute to the catalytic reaction.

Prior to recording the electroactivity of catalysts, the catalysts were activated by 15 cycles of CV scans over the range -1.6 to $-0.9 \mathrm{~V} v s$. $\mathrm{Ag} / \mathrm{AgCl}$. To study electrocatalytic activity and stability, polarization curves were acquired and chronoamperometry measurements were carried out at various current densities in $1.0 \mathrm{M} \mathrm{KOH}$ solution and in simulated seawater $(1.0 \mathrm{M} \mathrm{KOH}+0.6 \mathrm{M} \mathrm{NaCl})$. The performance with $\mathrm{iR}$ compensation ( $98 \%$ ) was obtained automatically from the electrochemical potentiostat. Electrochemical impedance spectroscopy (EIS) measurements were carried out using a France VSP-300 Bio-Logic instrument over the frequency range from $100 \mathrm{kHz}$ to $1 \mathrm{~Hz}$ at various HER overpotentials in $1 \mathrm{M} \mathrm{KOH}$; each scan was triplicated for confirmation. Simulation and analysis of EIS data were carried out using ZSimpWin software. ${ }^{2-3}$

Solar-cell-driven electrolysis measurements. To measure the efficiency of electrolysis as driven by perovskite solar cells, two solar cells in series $\left(9.24 \mathrm{~cm}^{2}\right.$ total $)$ were connected with an electrolyzer (anode and cathode each of $1 \mathrm{~cm}^{2}$ area). The electrode was activated $v s$. a graphite rod electrode $\left(100 \mathrm{~mA} / \mathrm{cm}^{2}\right.$ in $1 \mathrm{M} \mathrm{KOH}$ for $\left.1 \mathrm{~h}\right)$, washed with water and paired with a fresh $\mathrm{NiOOH} / \mathrm{Cu}$ catalyst before assembling it with the solar cells. The workstation CHI 760E was also connected in series to test the current in the circuit. For the calculation of solar to hydrogen efficiency (STH), ${ }^{4}$ the following equation was used.

$$
\mathrm{STH} \%=(\mathrm{j} \times 1.23 \mathrm{~V}) / 100 \mathrm{~mW} / \mathrm{cm}^{2} \times 100 \%
$$

Calculation methods. All calculations were implemented using the Vienna Ab initio Simulation Package (VASP), which is based on density functional theory (DFT). For the following calculations of properties, general gradient approximation (GGA) was 
used with the Perdew-Burke-Ernzerhof (PBE) functional to describe the exchangecorrelation potential..$^{5}$ All structural models were entirely relaxed until the ionic Hellmann-Feynman forces were smaller than $0.001 \mathrm{eV} / \AA$; the energy tolerances were less than $10^{-6} \mathrm{eV} /$ atom. The interaction between core electrons and valence electrons was described using the frozen-core projector-augmented wave (PAW) method. Wave functions were expanded on a plane wave basis with high energy using the plane-wave cutoff energy of $400 \mathrm{eV}$, and the corresponding gamma-centered Monkhorst-Pack ${ }^{6}$ electronic wavevector k-point samplings were denser than $0.2 \AA^{-1}$. Spin polarization was included in all calculations and Hubbard correction was included by using the rotationally invariant approach of Dudarev et al. with a $\mathrm{U}$ value of 6.2 for $\mathrm{Ni}^{7} \mathrm{~A}$ vacuum gap of $15 \AA$ was added to prevent interaction between slabs.

Different surfaces were created by starting from a bulk-relaxed structure of $\mathrm{Cu}$. First, a 64-atom, 4-layer, (111) slice of $\mathrm{Cu}$ was created. The bottom two layers of the slice were fixed at a bulk lattice constant and the top two layers were allowed to relax. For the surface with deposited $\mathrm{NiO}$, we started with a $\mathrm{Cu}$ surface and deposited four units of $\mathrm{NiO}$ (four $\mathrm{Ni}$ atoms and four $\mathrm{O}$ atoms) on the top surface. All $\mathrm{Ni}$ and $\mathrm{O}$ atoms and the top two layers of the $\mathrm{Cu}$ (111) surface were then relaxed until the simulation converged. For the hydroxy-functionalized surface with deposited $\mathrm{NiO}$, the one hydroxy group was bonded to a Ni atom. Similarly, another hydroxy group was bonded to another $\mathrm{Ni}$ atom. All Ni, atoms, $\mathrm{O}$ atoms, hydroxy groups, and the top two layers of the $\mathrm{Cu}$ (111) surface were then relaxed until the simulation converged.

For HER in alkaline solution, a multistep process was considered that included two reaction intermediates, the chemisorbed $\mathrm{H}_{2} \mathrm{O}$ molecule, and $\mathrm{H}$ atom:

$$
\begin{array}{cc}
\mathrm{H}_{2} \mathrm{O}+*+\mathrm{e}^{-} \rightarrow \mathrm{H}^{*}+\mathrm{OH}^{-} & \text {(Volmer step) } \\
2 \mathrm{H}^{*}+2 \mathrm{e}^{-} \rightarrow \mathrm{H}_{2} & \text { (Tafel step) } \\
\mathrm{H}^{*}+\mathrm{H}_{2} \mathrm{O}+\mathrm{e}^{-} \rightarrow \mathrm{H}_{2}+*+\mathrm{OH}^{-} & \text {(Heyrovsky step) }
\end{array}
$$

where the asterisks denote the catalyst surface. The free energy change for the Volmer and Heyrovsky steps should be the same at the equilibrium potential of HER. ${ }^{8}$ The water dissociation energy barrier of transition state was calculated through the nudged elastic band (NEB) method. ${ }^{9-10}$ For each step, the reaction Gibbs free energy $(\Delta \mathrm{G})$ in alkaline solution was defined as follows:

$$
\Delta \mathrm{G}=\Delta \mathrm{E}+\Delta E_{Z P E}-T \Delta S
$$

where $\Delta \mathrm{E}$ is the binding energy, $T$ is the temperature, $\Delta \mathrm{E}_{\mathrm{ZPE}}$ is the difference in zeropoint energy, and $\Delta \mathrm{S}$ is the entropy change. Because the vibration entropy of the adsorbed $\mathrm{H}^{*}$ is small, the entropy of adsorption of $1 / 2 \mathrm{H}_{2}$ is $\Delta \mathrm{S}_{\mathrm{H}} \approx 1 / 2 \mathrm{~S}^{0}{ }_{\mathrm{H} 2}$, where $\mathrm{S}_{\mathrm{H} 2}^{0}$ is the entropy of $\mathrm{H}_{2}$ in the gas phase under standard conditions.

The comparison of thermodynamic redox potential between $\mathrm{NiO} / \mathrm{Ni}$ and $\mathrm{Cu}_{2} \mathrm{O} / \mathrm{Cu}$ : To determine the redox potential of $\mathrm{NiO} / \mathrm{Ni}$, the Nernst equation is needed:

The electrode reaction is: 


$$
\begin{gathered}
\mathrm{Ox}+\mathrm{ne}^{-} \rightarrow \mathrm{Red} \\
2 \mathrm{NiO}+4 \mathrm{e}^{-} \leftrightharpoons 2 \mathrm{Ni}+\mathrm{O}_{2}
\end{gathered}
$$

So redox potential of $\mathrm{NiO} / \mathrm{Ni}(\mathrm{E}(\mathrm{NiO} / \mathrm{Ni}))$ can be calculated:

$$
\begin{aligned}
& \mathrm{E}(\mathrm{NiO} / \mathrm{Ni})=\mathrm{E}^{\theta}\left(\mathrm{Ni}^{2+} / \mathrm{Ni}\right)+\frac{\mathrm{RT}}{\mathrm{nF}} \log _{\left[\frac{\left[\frac{\mathrm{c}(\mathrm{Red})}{\mathrm{c}^{\theta}}\right]^{\mathrm{b}}}{\mathrm{c}^{\theta}}\right]^{\mathrm{b}}}^{\mathrm{c}^{\mathrm{b}}} \\
& =\mathrm{E}^{\theta}\left(\mathrm{Ni}^{2+} / \mathrm{Ni}\right)+\frac{\mathrm{RT}}{\mathrm{nF}^{2}} \log _{\mathrm{P}_{\mathrm{O} 2}} \\
& =-0.25+\frac{0.0592}{4} \log \frac{1}{0.21}=-0.18 \mathrm{~V}
\end{aligned}
$$

Where $\mathrm{E}^{\theta}\left(\mathrm{Ni}^{2+} / \mathrm{Ni}\right)$ is standard half-cell reduction potential $(-0.25 \mathrm{~V}), \mathrm{R}$ is the universal gas constant: $\mathrm{R}=8.31446261815324 \mathrm{~J} \mathrm{~K}^{-1} \mathrm{~mol}^{-1}$, $\mathrm{T}$ is the temperature in kelvins (room condition, $273.15 \mathrm{~K}$ ), $\mathrm{n}$ is the number of electrons transferred in the cell reaction or half-reaction, $\mathrm{F}$ is the Faraday constant, the number of coulombs per mole of electrons: $\mathrm{F}=96485.3321233100184 \mathrm{C} \mathrm{mol}^{-1}, \mathrm{P}_{\mathrm{O} 2}$ is the partial pressure of $\mathrm{O}_{2}$ inroom condition $(0.21 \mathrm{~atm}), \mathrm{c}(\mathrm{Ox})$ is the concentration of oxidation state, $\mathrm{c}(\mathrm{Red})$ is the concentration of reduction state, $\mathrm{a}$ and $\mathrm{b}$ are chemical activity for the relevant species.

And the redox potential of $\mathrm{Cu}_{2} \mathrm{O} / \mathrm{Cu}\left(\mathrm{E}\left(\mathrm{Cu}_{2} \mathrm{O} / \mathrm{Cu}\right)\right)$ in $1 \mathrm{M} \mathrm{KOH}$ is:

$$
\mathrm{Ox}+\mathrm{ne}^{-} \rightarrow \mathrm{Red}
$$

$$
2 \mathrm{Cu}_{2} \mathrm{O}+2 \mathrm{e}^{-}+\mathrm{H}^{+} \leftrightharpoons 2 \mathrm{Cu}+\mathrm{OH}^{-} \text {equation (2) in Figure 1a }
$$

$$
\begin{aligned}
\mathrm{E}\left(\mathrm{Cu}{ }_{2} \mathrm{O} / \mathrm{Cu}\right) & \left.=\mathrm{E}^{\theta}\left(\mathrm{Cu}^{1+} / \mathrm{Cu}\right)+\frac{\mathrm{RT}}{\mathrm{nF}} \log \frac{\left[\frac{\mathrm{c}(\mathrm{Ox})}{\mathrm{c}^{\theta}}\right]^{\mathrm{a}}}{\mathrm{c( \textrm {Red } )}}{ }^{\mathrm{b}} \mathrm{c}^{\theta}\right] \\
& =\mathrm{E}^{\theta}\left(\mathrm{Cu}^{1+} / \mathrm{Cu}\right)+\frac{\mathrm{RT}}{\mathrm{nF}} \log \frac{\mathrm{c}\left(\mathrm{H}^{+}\right)}{\mathrm{c}\left(\mathrm{OH}^{-}\right)} \\
& =0.521+\frac{0.0592}{4} \log \frac{10^{-14}}{1}=0.3168 \mathrm{~V}
\end{aligned}
$$

Where $\mathrm{E}^{\theta}\left(\mathrm{Cu}^{1+} / \mathrm{Cu}\right)$ is the standard half-cell reduction potential $(0.521 \mathrm{~V}), \mathrm{c}\left(\mathrm{H}^{+}\right)$ is the concentration of $\mathrm{H}^{+}\left(10^{-4} \mathrm{M}\right), \mathrm{c}\left(\mathrm{OH}^{-}\right)$is the concentration of $\mathrm{OH}^{-}(1 \mathrm{M})$.

The thermodynamic redox potential of $\mathrm{NiO} / \mathrm{Ni}$ is around $-0.18 \mathrm{~V}$, much lower than that of $\mathrm{Cu}_{2} \mathrm{O} / \mathrm{Cu}(0.3186 \mathrm{~V})$. So the reduction of $\mathrm{Cu}_{2} \mathrm{O}$ firstly and easily occurs not the reduction of $\mathrm{NiO}$. And based on the explanation in the main text, the $\mathrm{NiO}$ in $\mathrm{NiO} / \mathrm{Cu}_{2} \mathrm{O} / \mathrm{Cu}$ only suffers the $\mathrm{OH}^{-}$adsorption while the $\mathrm{Cu}_{2} \mathrm{O} / \mathrm{Cu}$ is reduced to $\mathrm{Cu}$, which supports our explanation. 


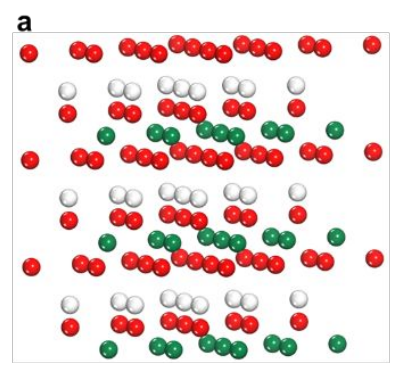

b

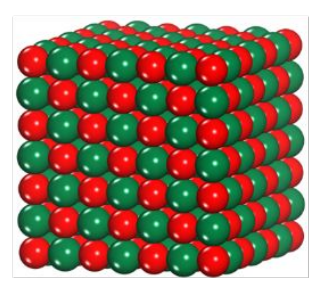

$\bigcirc_{\mathrm{Ni}} \odot \mathrm{O} \mathrm{OH}$ c

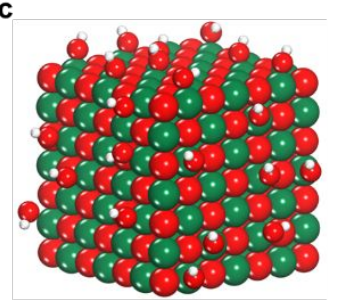

d

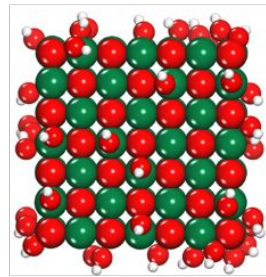

Figure S1. a-c, Proposed crystal configuration differences in the main view among $\mathrm{NiOOH}, \mathrm{NiO}$, and $\mathrm{OH}^{-}$-functionalized $\mathrm{NiO}$. d, Top view of (c). The local $\mathrm{OH}^{-}$ functionalized $\mathrm{NiO}$ structure shows an obvious distinct conformation and atomic arrangement compared with $\mathrm{NiOOH}$, wherein the nature of $\mathrm{NiO}$ is still inherited but just goes through the random $\mathrm{OH}^{-}$adsorption on the surface of $\mathrm{NiO}$. 

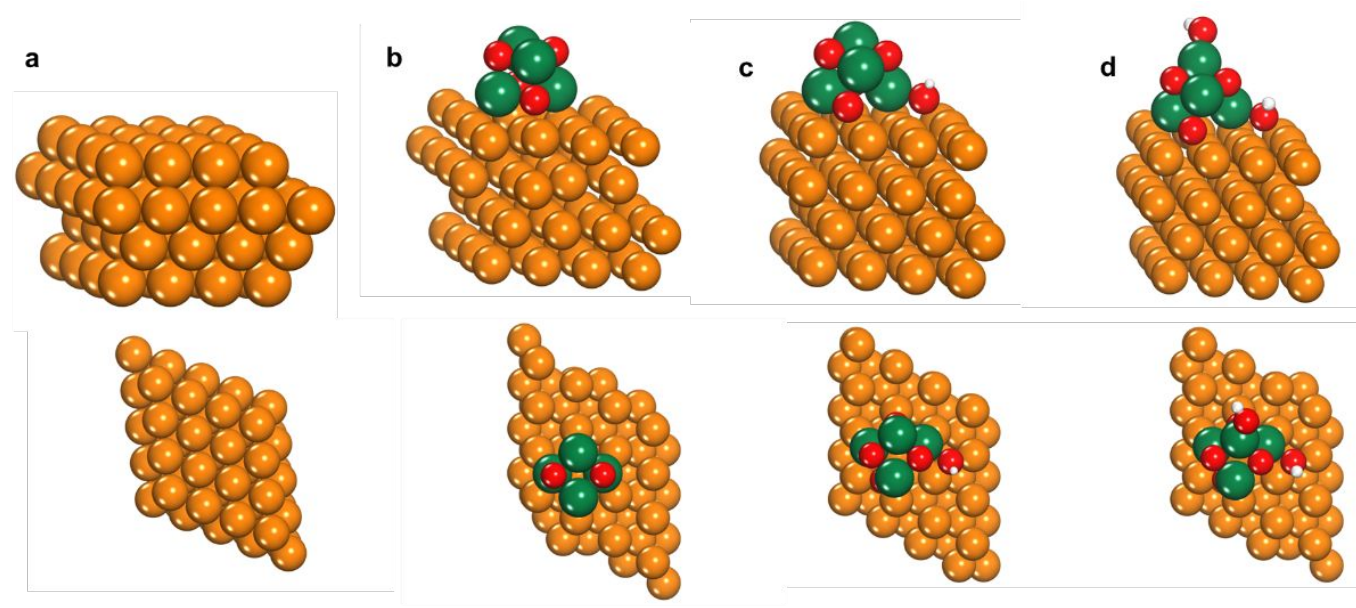

○cu $\odot \mathrm{Ni}$ ○O $\mathrm{OH}$

Figure S2. a-d, Surficial configurations from the main view (upper) and top view images (down) of four catalysts for calculation $(\mathrm{Cu}, \mathrm{NiO} / \mathrm{Cu}, \mathrm{HO}-\mathrm{NiO} / \mathrm{Cu}$ and $2 \mathrm{HO}-$ $\mathrm{NiO} / \mathrm{Cu})$.
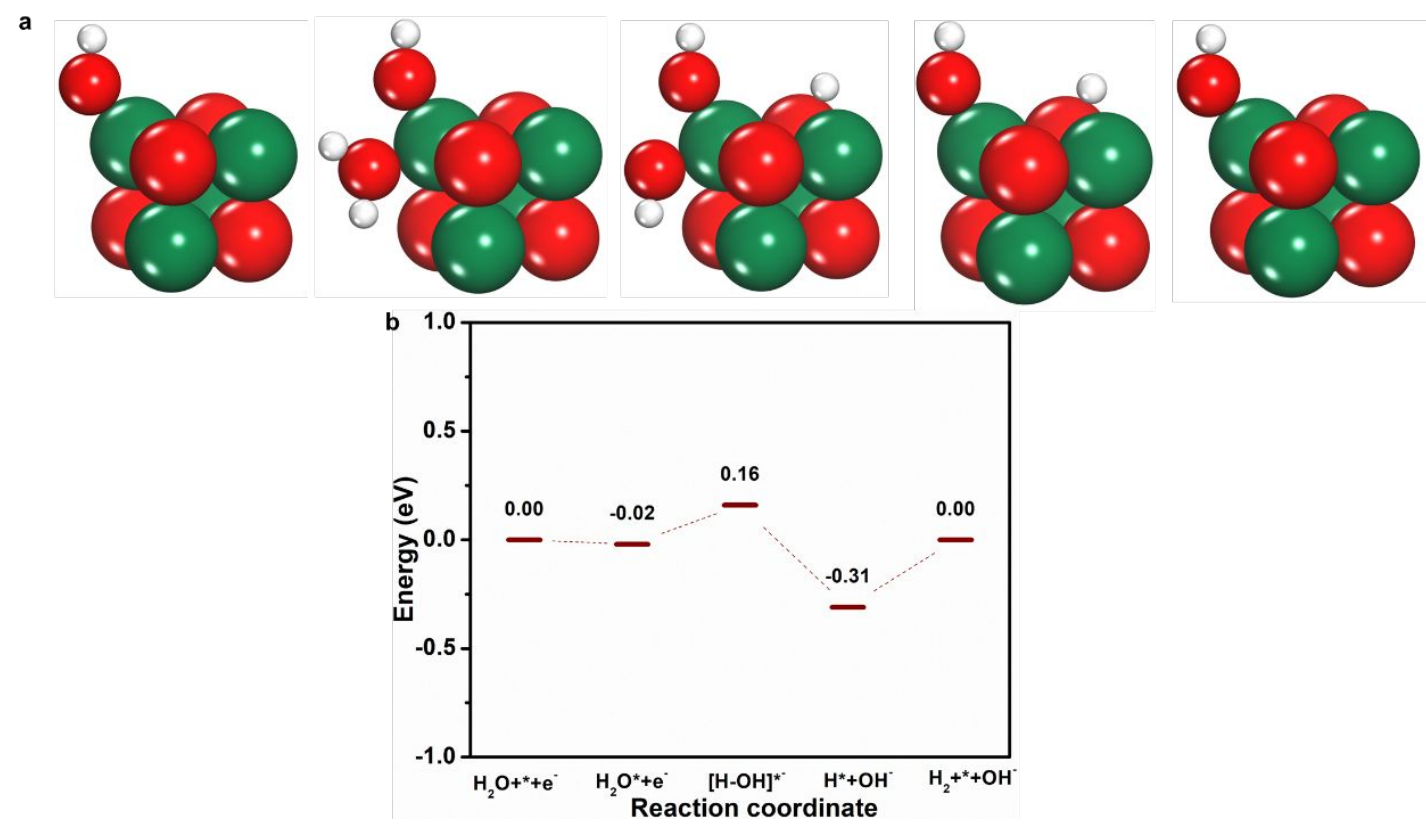

Figure S3. a,b, Surficial configurations of $\mathrm{OH}^{-}$-modified $\mathrm{NiO}$ and corresponding free energy diagrams of intermediates adsorbing during the HER reaction. The low water dissociative energy barrier of $0.14 \mathrm{eV}$, similar to that of $\mathrm{HO}-\mathrm{NiO} / \mathrm{Cu}$, suggests the comparable ability to supplement of $\mathrm{H}^{*}$ source. But without a $\mathrm{NiO} / \mathrm{Cu}$ interface, interfacial $\mathrm{H}^{*}$ migration would not occur, yielding unsatisfactory HER performance at the site of $\mathrm{O}$ in $\mathrm{NiO}\left(\Delta \mathrm{G}\left(\mathrm{H}_{2}\right)=-0.31 \mathrm{eV}\right)$. 

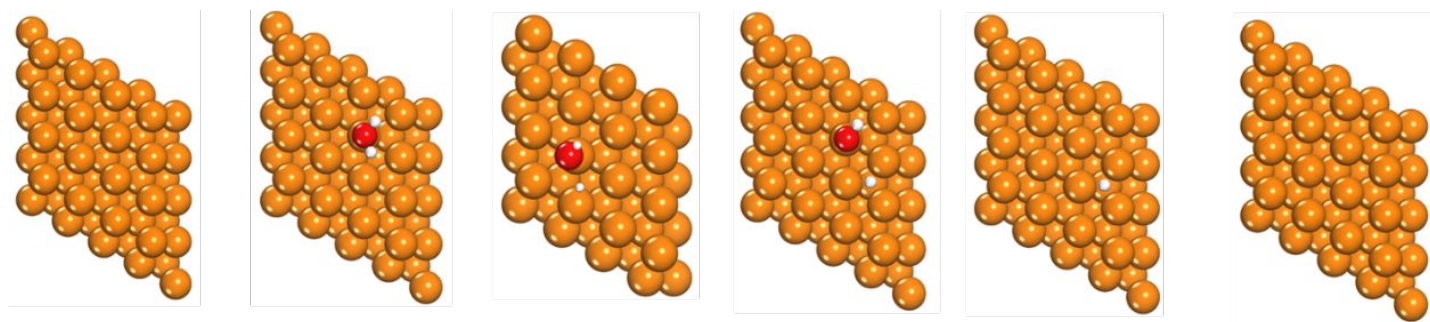

Figure S4. HER reaction steps on the $\mathrm{Cu}$ surface. (From left to right: active $\mathrm{Cu}$, water adsorption, activated $\mathrm{H}_{2} \mathrm{O}$ dissociation of the transition state, water dissociation, adsorption of $\mathrm{H}$, active $\mathrm{Cu}$ )
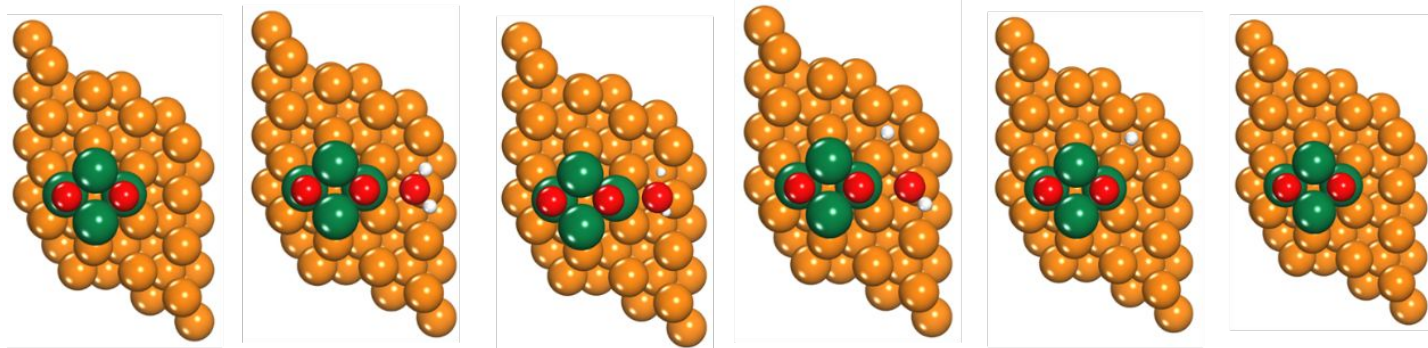

Figure S5. HER reaction steps on the $\mathrm{NiO} / \mathrm{Cu}$ surface. (From left to right: active $\mathrm{NiO} / \mathrm{Cu}$, water adsorption, activated $\mathrm{H}_{2} \mathrm{O}$ dissociation of the transition state, water dissociation, adsorption of $\mathrm{H}$ desorption of $\mathrm{OH}^{-}$, active $\mathrm{NiO} / \mathrm{Cu}$ )
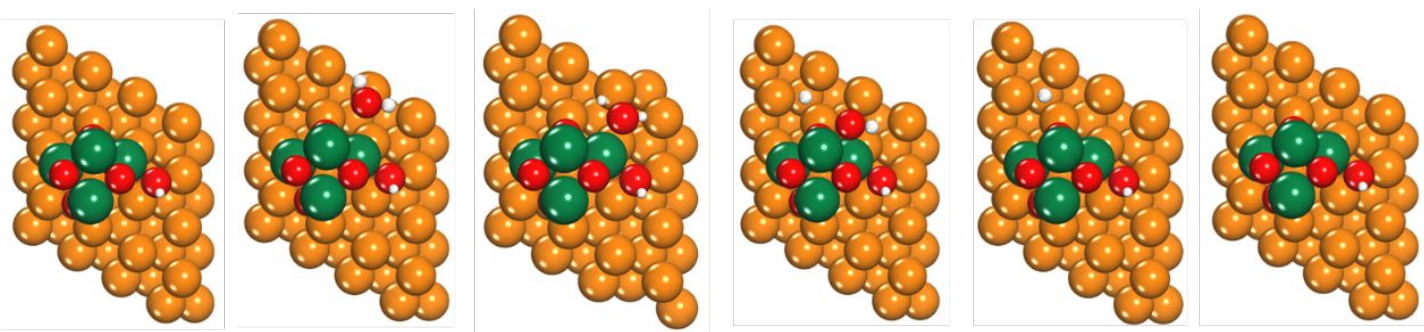

Figure S6. HER reaction steps on the $\mathrm{HO}-\mathrm{NiO} / \mathrm{Cu}$ surface. (From left to right: active $\mathrm{HO}-\mathrm{NiO} / \mathrm{Cu}$, water adsorption, activated $\mathrm{H}_{2} \mathrm{O}$ dissociation of the transition state, water dissociation, adsorption of $\mathrm{H}$ and desorption of $\mathrm{OH}^{-}$, active $\mathrm{HO}-\mathrm{NiO} / \mathrm{Cu}$ )
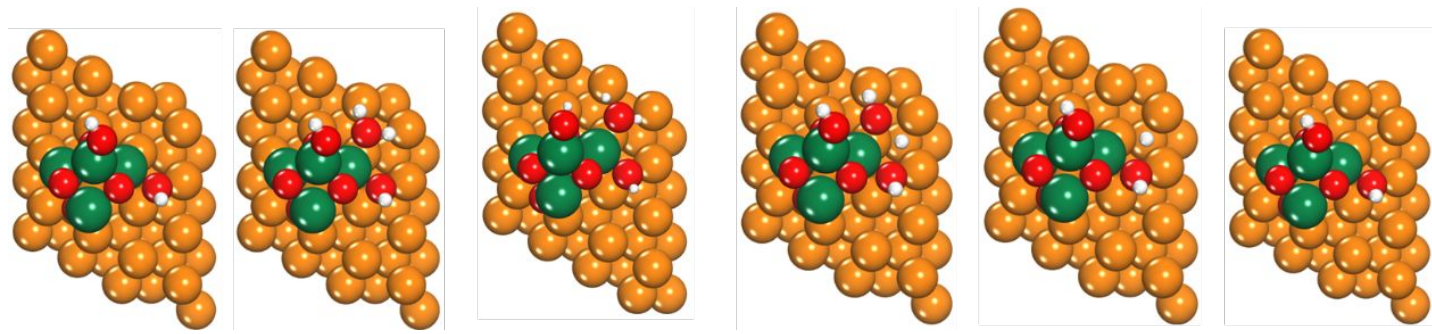

Figure S7. HER reaction steps on the $2 \mathrm{HO}-\mathrm{NiO} / \mathrm{Cu}$ surface. (From left to right: active $2 \mathrm{HO}-\mathrm{NiO} / \mathrm{Cu}$, water adsorption, activated $\mathrm{H}_{2} \mathrm{O}$ dissociation of the transition state, water dissociation, adsorption of $\mathrm{H}$ and desorption of $\mathrm{OH}^{-}$, active $\mathrm{HO}_{\mathrm{H}^{-}} \mathrm{NiO} / \mathrm{Cu}$ ) 

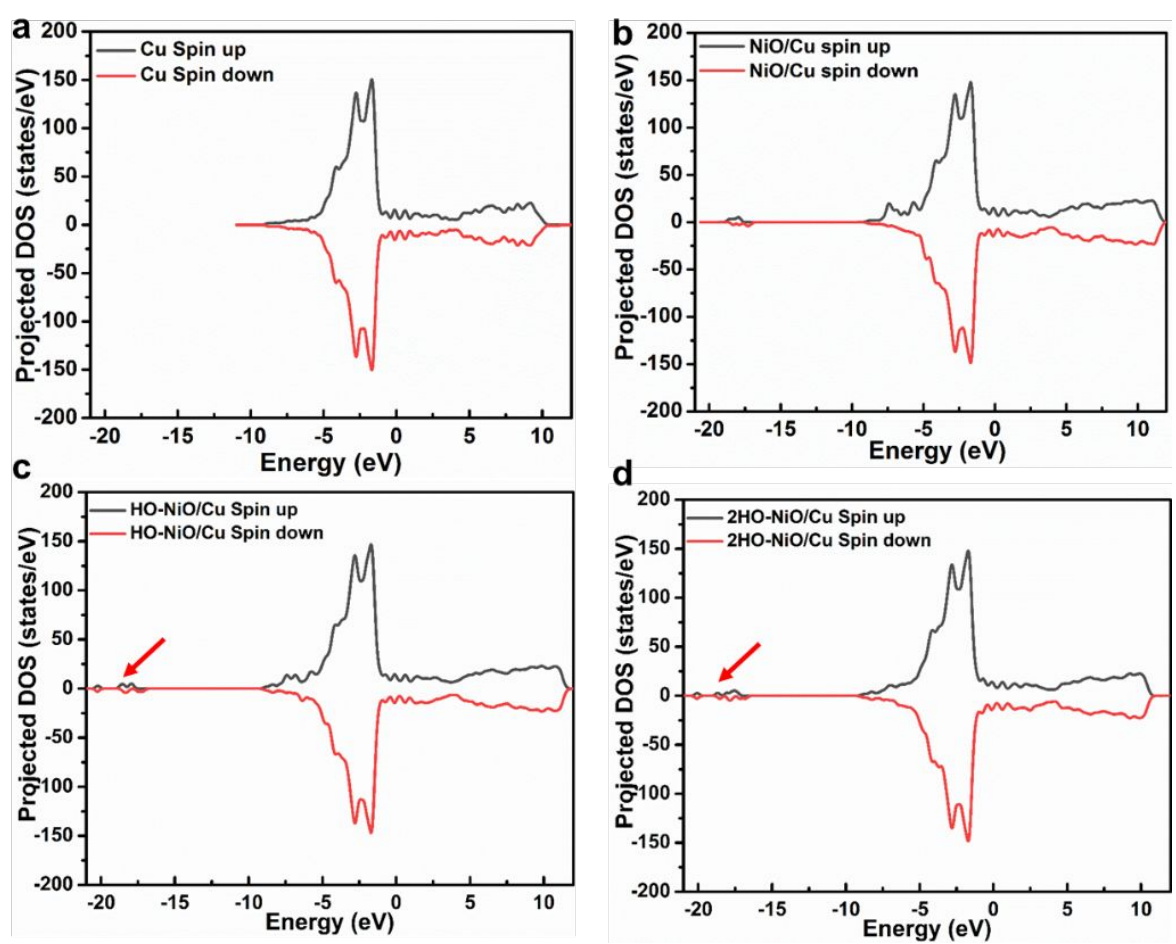

Figure S8. a-d, Partial DOS plots of catalysts. Among these, new states emerged in $\mathrm{HO}-\mathrm{NiO} / \mathrm{Cu}$ and $2 \mathrm{HO}-\mathrm{NiO} / \mathrm{Cu}$, revealing d-band centers farther from the Fermi energy level (E-Fermi).

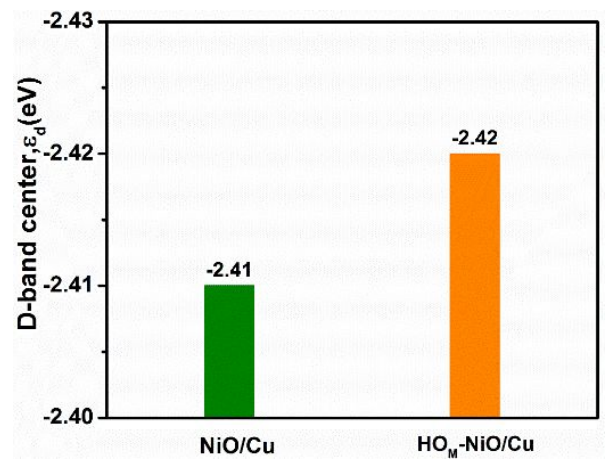

Figure S9. Value of d-band center of $\mathrm{NiO} / \mathrm{Cu}$ and $\mathrm{HO}_{\mathrm{M}}-\mathrm{NiO} / \mathrm{Cu}$. D-band centers were calculated by the following formula. ${ }^{20}$

$$
\varepsilon_{d}=\frac{\int_{-\infty}^{\infty} n_{d}(\varepsilon) \varepsilon d \varepsilon}{\int_{-\infty}^{\infty} n_{d}(\varepsilon) d \varepsilon}
$$

Where $\varepsilon_{d}$ is the d-band center. $\varepsilon$ is the energy, and $n_{d}(\varepsilon)$ the electron density.

In ELF, the electron density of nearby $\mathrm{Ni}$ and $\mathrm{O}$ sites was significantly reduced after hydroxylation, demonstrating that $\mathrm{OH}^{-}$modification makes the electrons transferring from $\mathrm{Ni}$ to $\mathrm{O}$ and increases the oxidation state of $\mathrm{Ni}$, consistent with the results of XPS and XANES. Due to lowered electron density, intrinsic $O$ sites have alleviated adsorption towards active $\mathrm{H}^{*}$ so that hydrogen spillover will readily happen. 


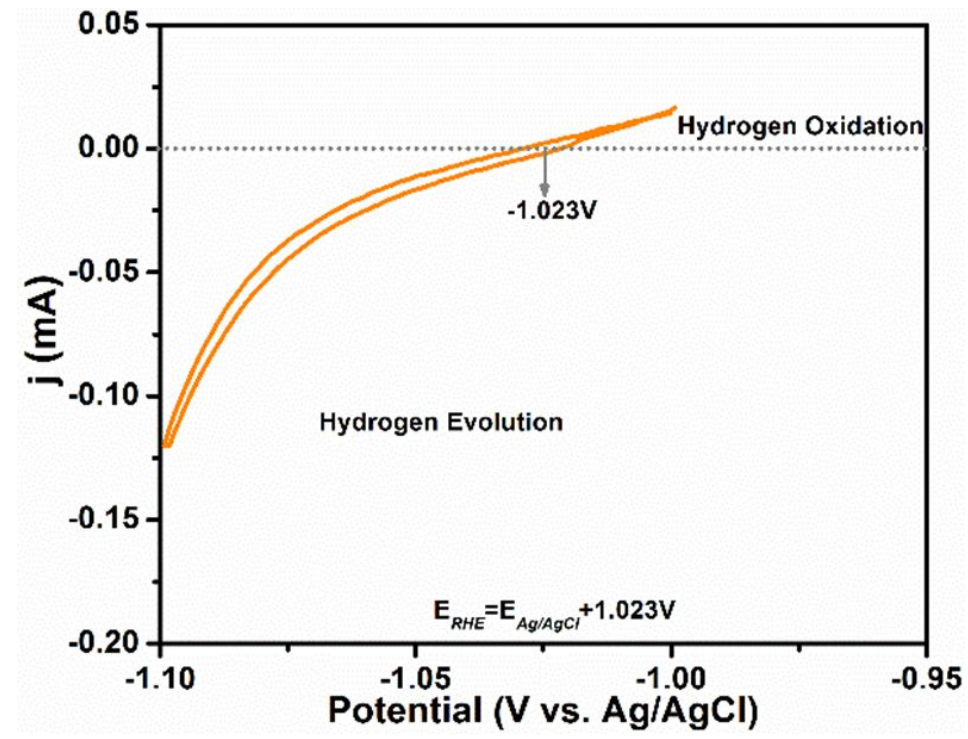

Figure S10. CV result of RHE calibration in $1 \mathrm{M} \mathrm{KOH}$ before tests.

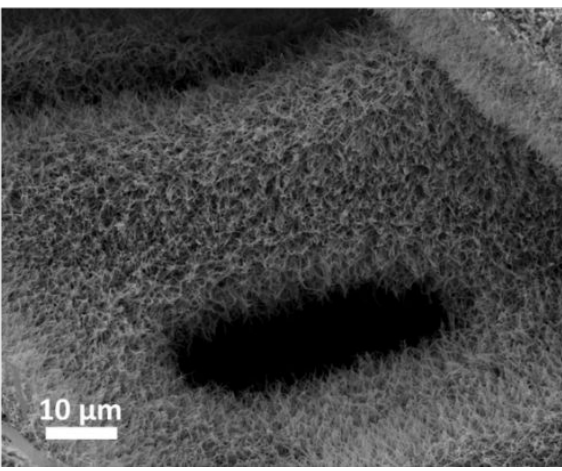

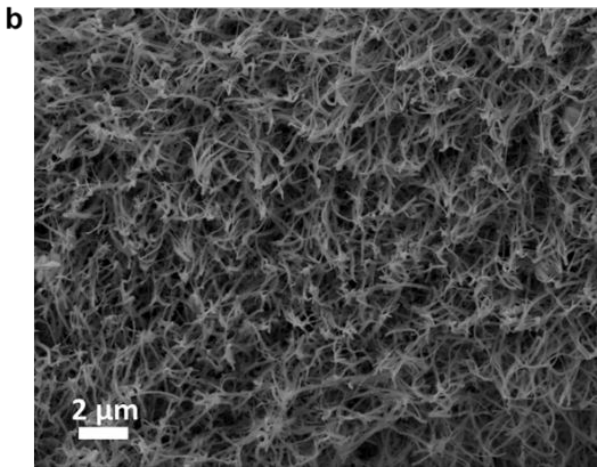

$2 \mu \mathrm{m}$

Figure S11. a,b, SEM images of Cu nanowire substrate.

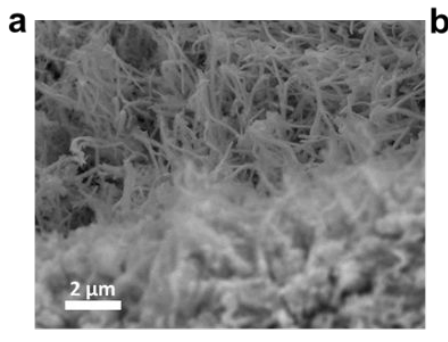

d

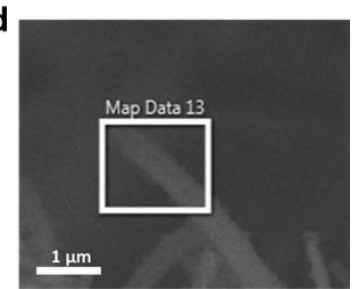

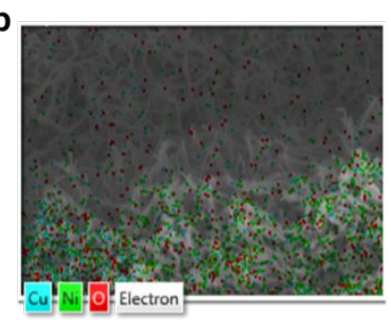

$\longdiv { 1 0 \text { NiK } }$

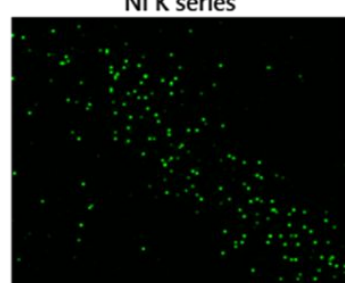

c

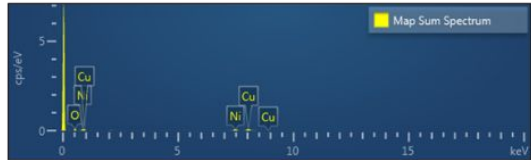

O K series

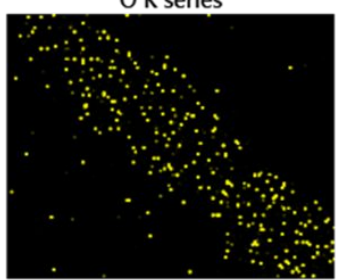

Cu K series

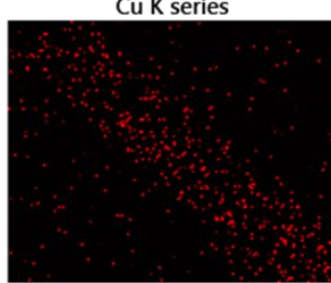

Figure S12. a,b, SEM images of $\mathrm{NiOOH} / \mathrm{Cu}$. c,d, Corresponding EDS images and elemental mapping. 

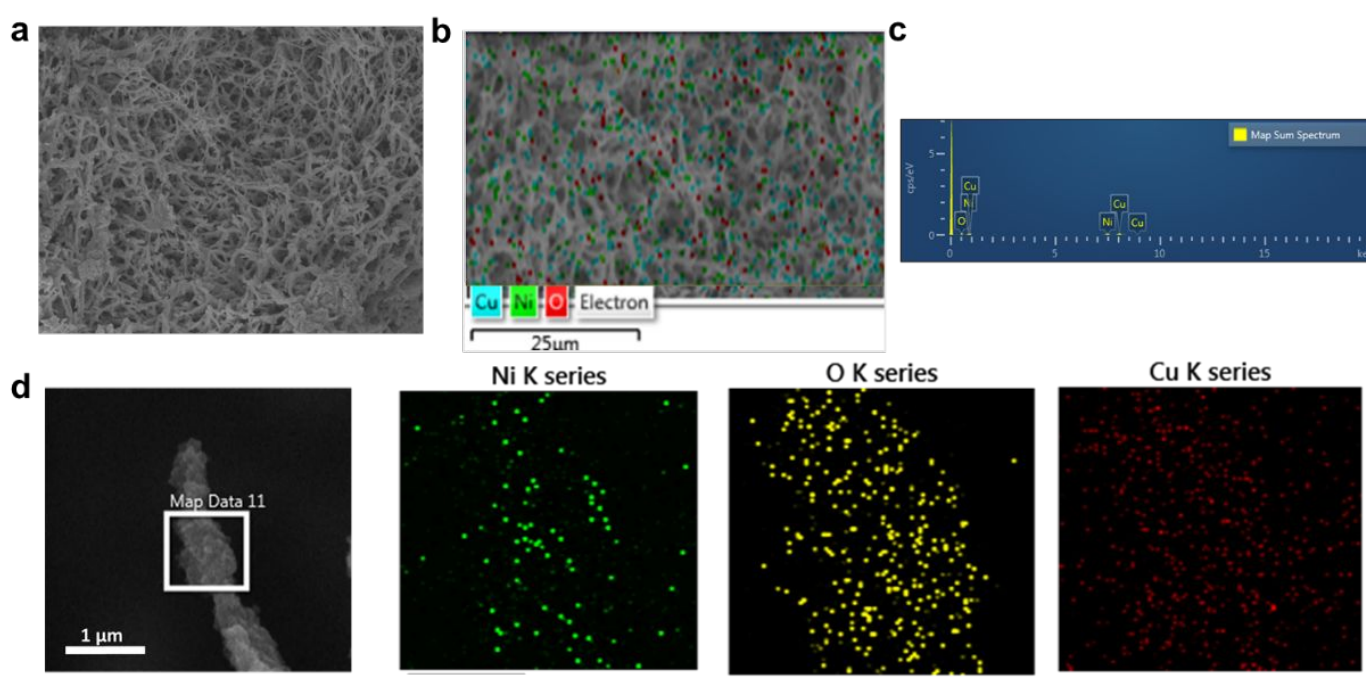

Figure S13. a,b, SEM images of $\mathrm{NiO} / \mathrm{Cu}_{2} \mathrm{O} / \mathrm{Cu}$. c,d, Corresponding EDS images and elemental mapping.
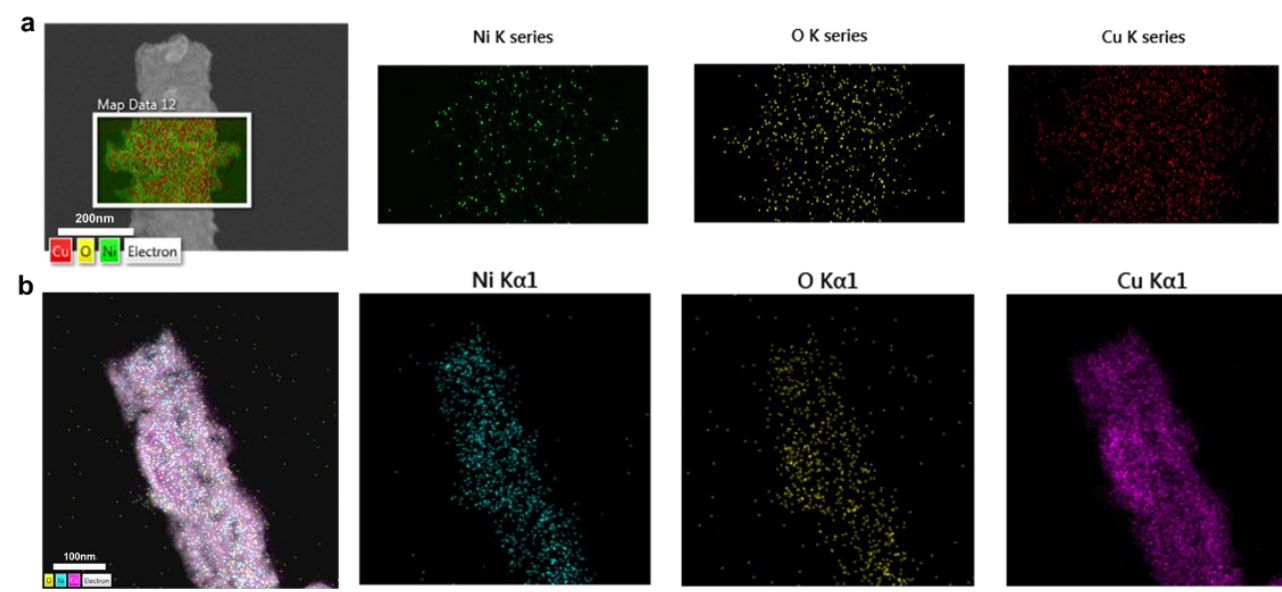

Ni $K \alpha 1$

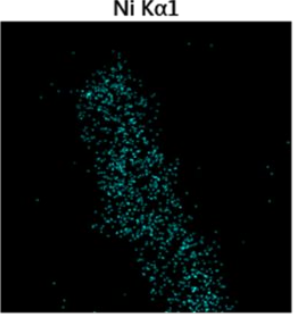

c
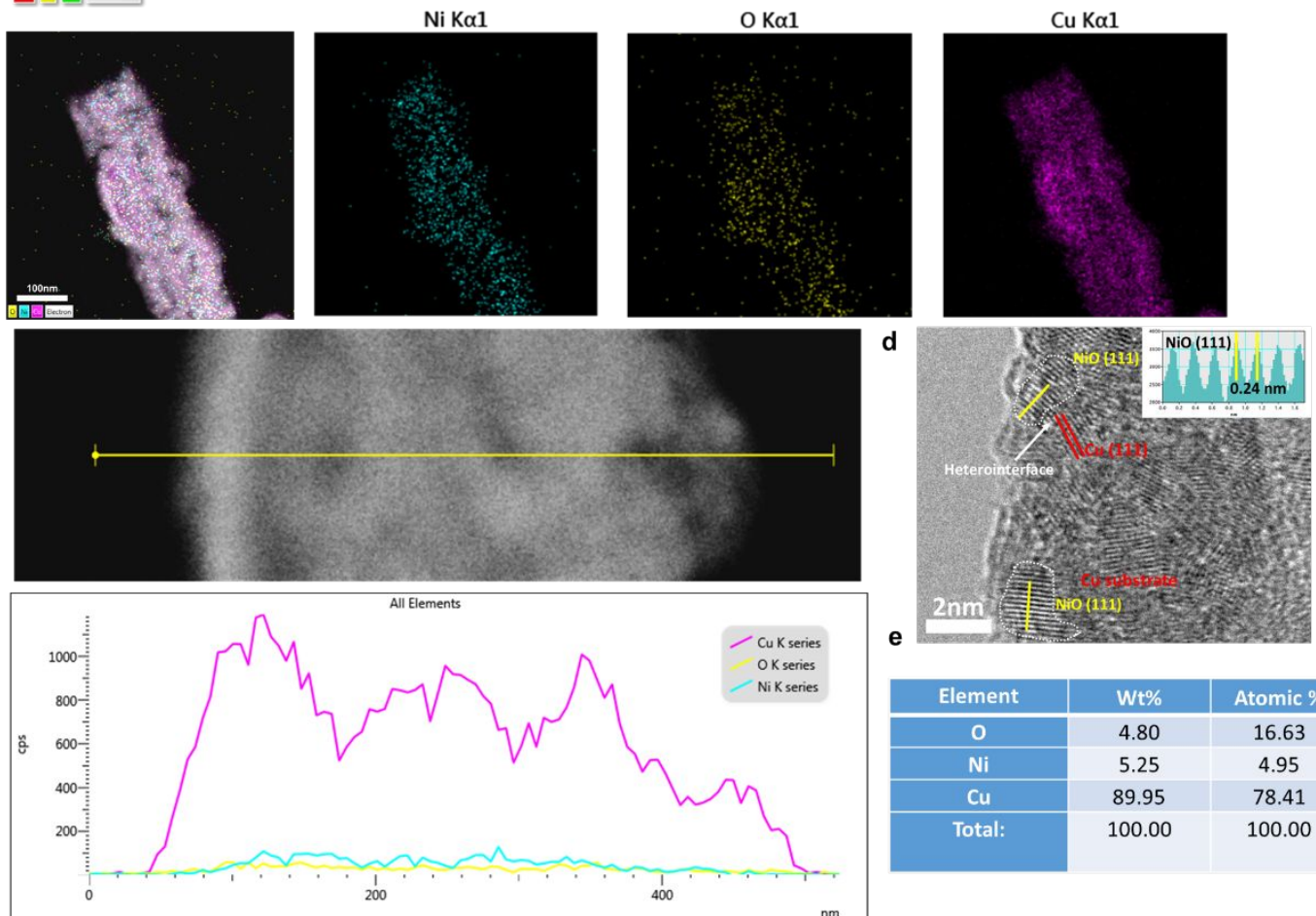

Figure S14. a,b SEM and TEM images of $\mathrm{HO}_{\mathrm{M}}-\mathrm{NiO} / \mathrm{Cu}$ and corresponding elemental mapping. c,e elemental line scan and elemental ratio from TEM. d, the HRTEM of $\mathrm{HO}_{\mathrm{M}}-\mathrm{NiO} / \mathrm{Cu}$ shows the lattice of $\mathrm{NiO}$ and its interaction with $\mathrm{Cu}$. The random nanoparticles were partially embedded into the $\mathrm{Cu}$ surface in $\mathrm{HO}_{\mathrm{M}^{-}} \mathrm{NiO} / \mathrm{Cu}$. Moreover, 
due to the surficial $\mathrm{Cu}$ had an amorphous conversion during the electrochemical reduction, the clear $\mathrm{NiO}$ lattice (111) embedded into $\mathrm{Cu}$ can be readily distinguished. And the lattice interface of $\mathrm{Cu}$ (111) and $\mathrm{NiO}$ (111) is shown in HRTEM, giving a heterointerface channel. The elemental line scan and element ratio from the TEM illustrated that $\mathrm{Cu}$ is a dominant component and $\mathrm{NiO}$ was partly grafted into the $\mathrm{Cu}$ subsurface rather than the geometric core-shell relationship. Thus it is reliable that heterointerface existed between $\mathrm{NiO}$ and $\mathrm{Cu}$.
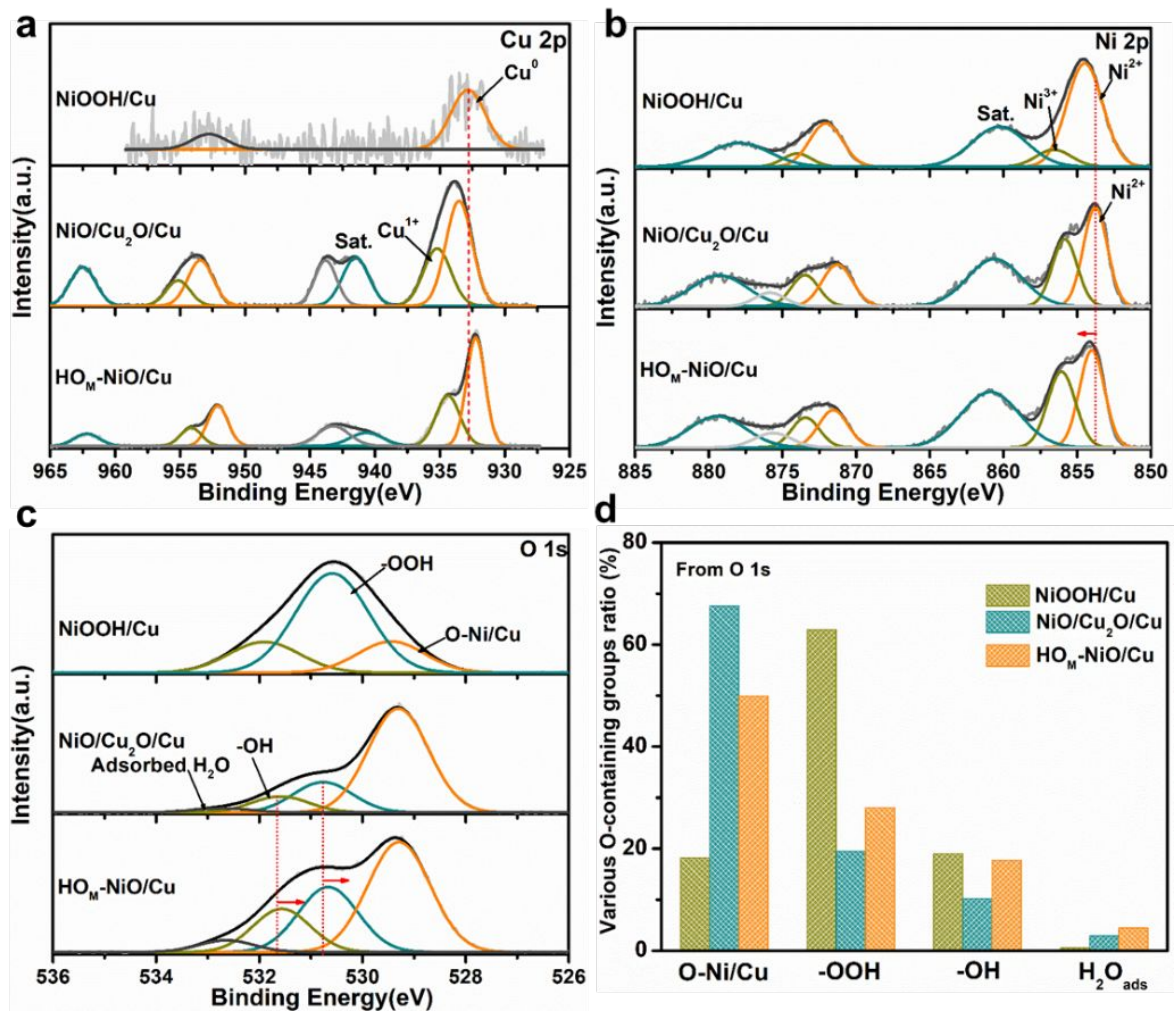

Figure S15. a. $\mathrm{Cu} 2 \mathrm{p}$ b Ni 2p, and c O 1s high-resolution XPS spectra of $\mathrm{NiOOH} / \mathrm{Cu}$, $\mathrm{NiO} / \mathrm{Cu}_{2} \mathrm{O} / \mathrm{Cu}$, and $\mathrm{HO}_{\mathrm{M}}-\mathrm{NiO} / \mathrm{Cu}$ (in-situ modification in $1 \mathrm{M} \mathrm{KOH}$ ) were conducted under normal condition. $\mathrm{d}$, Concentration ratio of various O-containing species obtained from $\mathrm{O} 1 \mathrm{~s}$. Representative peaks of $\mathrm{Cu} 2 \mathrm{p}$ and $\mathrm{Ni} 2 \mathrm{p}$ in $\mathrm{HO}_{\mathrm{M}}-\mathrm{NiO} / \mathrm{Cu}$ undergo known alterations including binding energy and oxidation states relative to $\mathrm{NiO} / \mathrm{Cu}_{2} \mathrm{O} / \mathrm{Cu}$. However, in the $\mathrm{O} 1$ s spectra, negligible $-\mathrm{OH}$ and $-\mathrm{OOH}$ configurations can be noticed on $\mathrm{NiO} / \mathrm{Cu}_{2} \mathrm{O} / \mathrm{Cu}$. In sharp contrast, dominated -OH groups accompanied by $-\mathrm{OOH}$ remain on the surface of $\mathrm{HO}_{\mathrm{M}}-\mathrm{NiO} / \mathrm{Cu}$. In this case, it's credible that $-\mathrm{OH}$ and $-\mathrm{OOH}$ were extrinsically generated and then strongly adsorbed on $\mathrm{Ni}$ sites of $\mathrm{HO}_{\mathrm{M}}-\mathrm{NiO} / \mathrm{Cu}$. 

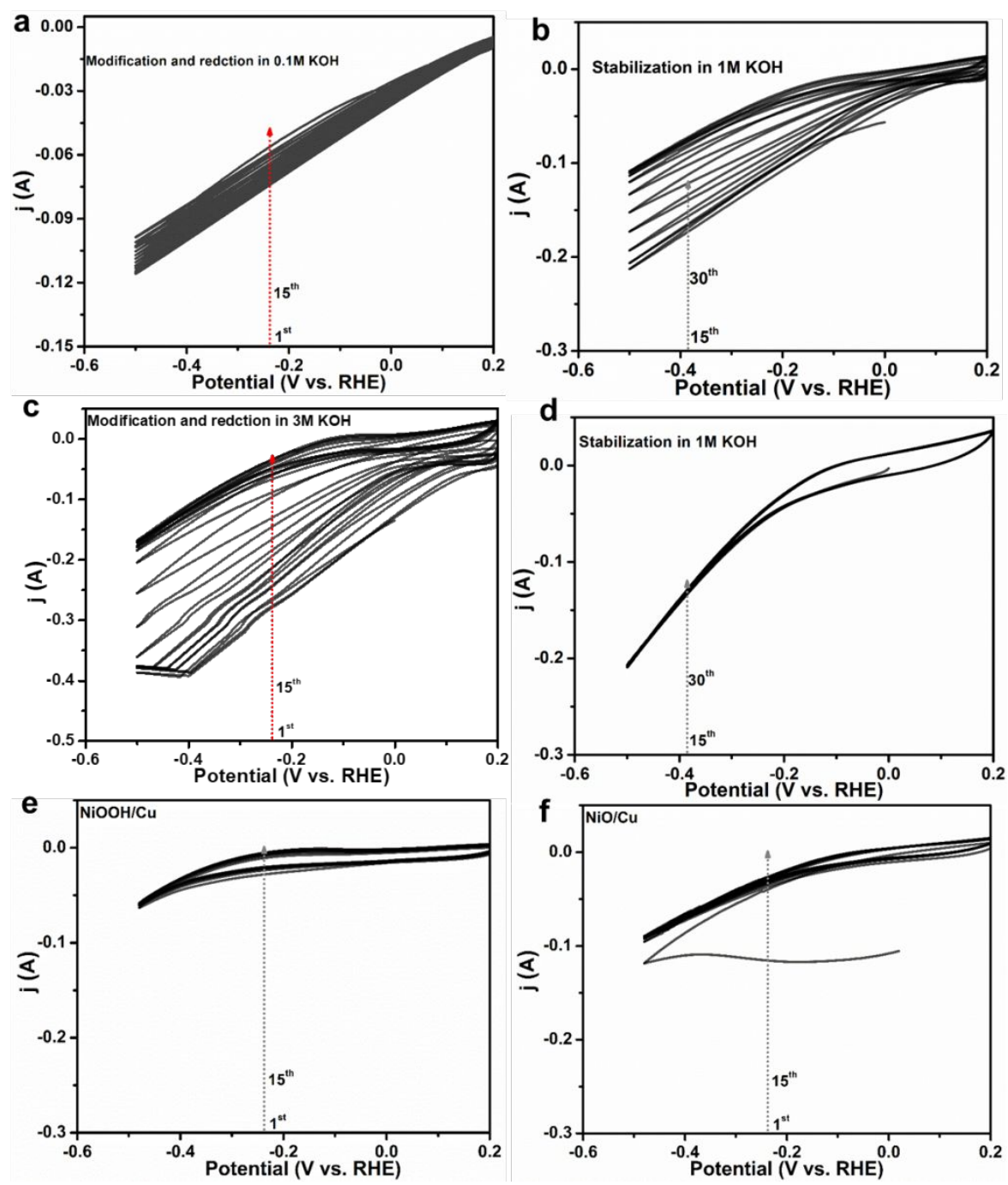

Figure S16. a,c Initially cathodic electrode cyclic voltage curves (15 cycles) acquired during $\mathrm{Cu}(\mathrm{I})$ conversion and in situ $\mathrm{HO}^{-}$functionalization on $\mathrm{NiO} / \mathrm{Cu}$ in $0.1 \mathrm{M} \mathrm{KOH}$ and $3 \mathrm{M} \mathrm{KOH}$ (working electrode surface area: $0.5 \mathrm{~cm}^{-2}$ ) to give $\mathrm{HO}_{\mathrm{L}}-\mathrm{NiO} / \mathrm{Cu}$ and $\mathrm{HO}_{\mathrm{H}}-\mathrm{NiO} / \mathrm{Cu}$. b,d Subsequent 15 cycles of stabilized $\mathrm{CV}$ in $1 \mathrm{M} \mathrm{KOH}$. The $\mathrm{HO}_{\mathrm{L}^{-}}$ $\mathrm{NiO} / \mathrm{Cu}$ could not be completely activated and reduced to be a metallic $\mathrm{Cu}$ surface due to the lower concentrated $\mathrm{OH}^{-}$and conductivity in $0.1 \mathrm{M} \mathrm{KOH}$. Conversely, $\mathrm{HO}_{\mathrm{H}^{-}}$ $\mathrm{NiO} / \mathrm{Cu}$ underwent a similar evolution process as $\mathrm{HO}_{\mathrm{M}^{-}} \mathrm{NiO} / \mathrm{Cu}$. e,f Initially cathodic electrode cyclic voltage curves (15 cycles) of $\mathrm{NiOOH} / \mathrm{Cu}$ and $\mathrm{NiO} / \mathrm{Cu}$ acquired in 0.1 $\mathrm{M} \mathrm{KOH}$. In addition to the phenomena of hydrogen gas bubble, almost no current attenuation was observed during the initial 15 cycles $\mathrm{CV}$, meaning control samples catalyze the HER as long as the circuit was connected. These findings are distinct from the investigations about $\mathrm{NiO} / \mathrm{Cu}_{2} \mathrm{O} / \mathrm{Cu}$. 

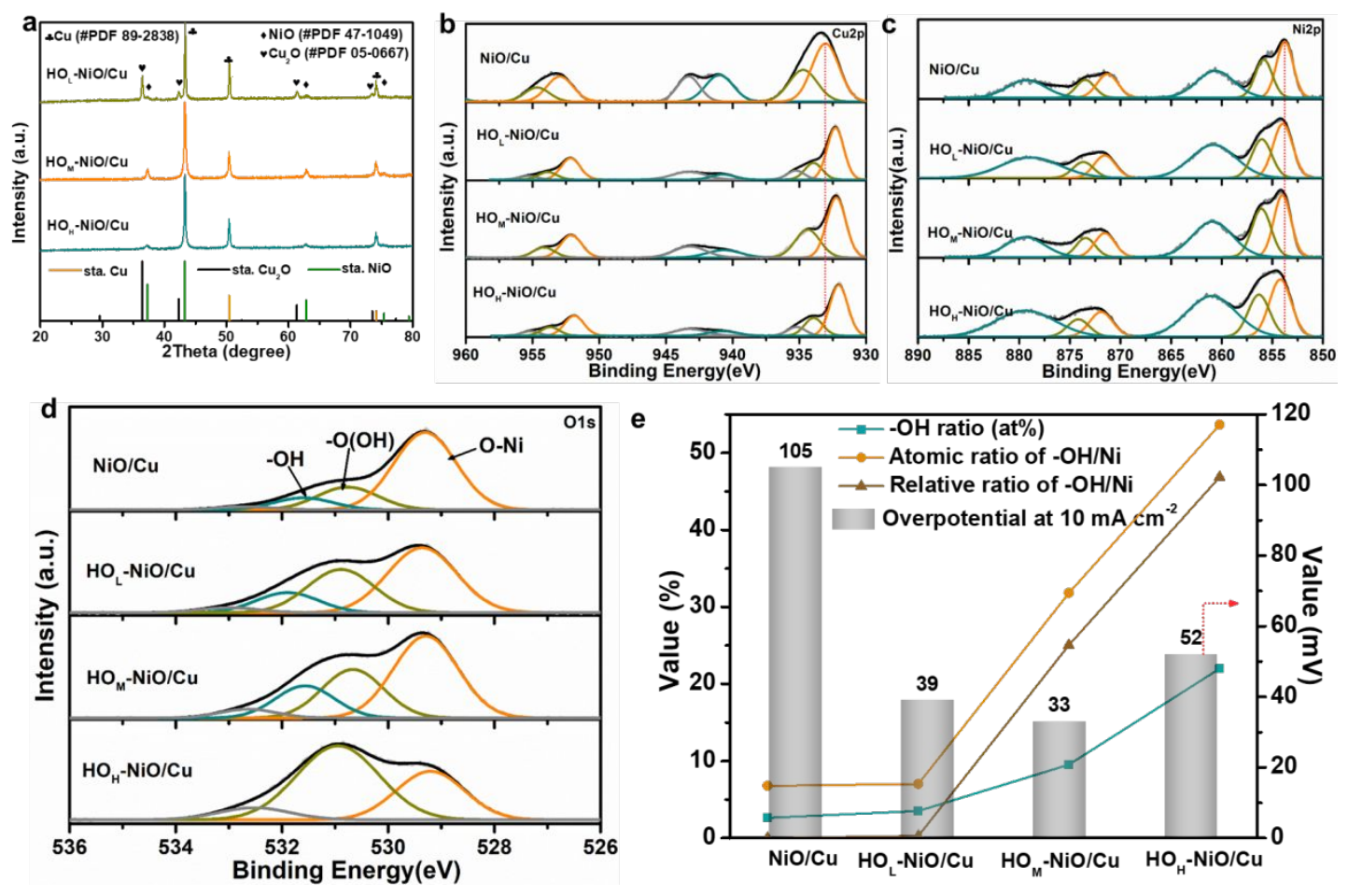

Figure S17. a XRD spectra showing the differences among catalysts. b-d, (b) $\mathrm{Cu} 2 \mathrm{p}$, (c) $\mathrm{Ni} 2 \mathrm{p}$, and (d) $\mathrm{O} 1 \mathrm{~s}$ high-resolution XPS signals of $\mathrm{HO}_{\mathrm{L}}-\mathrm{NiO} / \mathrm{Cu}, \mathrm{HO}_{\mathrm{M}}-\mathrm{NiO} / \mathrm{Cu}$, and $\mathrm{HO}_{\mathrm{H}}-\mathrm{NiO} / \mathrm{Cu}$. e, The relationship between hydroxylation coverage and HER catalytic performance. $\mathrm{HO}_{\mathrm{L}}-\mathrm{NiO} / \mathrm{Cu}$ maintained a large proportion of $\mathrm{Cu}_{2} \mathrm{O}$ and had nearly identical chemical states of $\mathrm{NiO}$ as those of the original $\mathrm{NiO}$, suggesting it is not an expected model. In the case of $\mathrm{HO}_{\mathrm{H}}-\mathrm{NiO} / \mathrm{Cu}$, enrichment of the hydroxyl ratio was observed, and intact metallic $\mathrm{Cu}$ was present in the sample. But the $\mathrm{OH}^{-}$coverage seems too high to expose the rich active $\mathrm{NiO}$ sites for reaction. The detailed composition analysis from the XPS spectra shows the surficial-OH component ratio is around 6-7\% on the $\mathrm{NiO} / \mathrm{Cu}$ and $\mathrm{HO}_{\mathrm{L}}-\mathrm{NiO} / \mathrm{Cu}$ surface $\left(\mathrm{HO}_{\mathrm{L}}-\mathrm{NiO} / \mathrm{Cu}\right.$ represents an unreliable system due to the insufficient reduction of $\mathrm{Cu}_{2} \mathrm{O}$.). Such low values only introduce a negligible effect on the catalytic behavior of $\mathrm{NiO}$. In sharp contrast, the $\mathrm{HO}_{\mathrm{M}}-\mathrm{NiO} / \mathrm{Cu}$ and $\mathrm{HO}_{\mathrm{H}^{-}}$ $\mathrm{NiO} / \mathrm{Cu}$ have respective $32 \%$ and $53 \%$ coverage of $-\mathrm{OH}$ on each surface, which undoubtedly affects the catalytic reaction. Furthermore, the relative ratio between $-\mathrm{OH}$ and $\mathrm{Ni}$ centers can be estimated as around $26 \%$ and $45 \%$ on $\mathrm{HO}_{\mathrm{M}}-\mathrm{NiO} / \mathrm{Cu}$ and $\mathrm{HO}_{\mathrm{H}^{-}}$ $\mathrm{NiO} / \mathrm{Cu}$ if it assumes that $\mathrm{NiO} / \mathrm{Cu}$ has a clean surface (Figure $\mathrm{S} 17 \mathrm{e}$ ). That is, the $-\mathrm{OH}$ modification proportion on real catalysts has a higher matched degree with $\mathrm{HO}-\mathrm{NiO} / \mathrm{Cu}$ and $2 \mathrm{HO}-\mathrm{NiO} / \mathrm{Cu}$ of theoretical models. Since $\mathrm{HO}_{\mathrm{L}}-\mathrm{NiO} / \mathrm{Cu}$ surface has a similarly lower hydroxylation degree with $\mathrm{NiO} / \mathrm{Cu}, \mathrm{HO}_{\mathrm{L}}-\mathrm{NiO} / \mathrm{Cu}$ cannot undergo a maximum activation under $0.1 \mathrm{M} \mathrm{KOH}$ condition, representing an unreliable system due to the insufficient reduction of $\mathrm{Cu}_{2} \mathrm{O}$. When further measuring the HER performance in $1 \mathrm{M}$ $\mathrm{KOH}$, it has to experience an almost identical evolution process with $\mathrm{HO}_{\mathrm{M}}-\mathrm{NiO} / \mathrm{Cu}$. Thus this process results in $\mathrm{HO}_{\mathrm{L}}-\mathrm{NiO} / \mathrm{Cu}$ showing similarly excellent performance with an overpotential of $39 \mathrm{mV}$ compared with $\mathrm{HO}_{\mathrm{M}}-\mathrm{NiO} / \mathrm{Cu}(33 \mathrm{mV}$ ) (Figure $\mathrm{S} 17 \mathrm{e}$ ). Once the relative hydroxylation degree reaches about $26 \%$ on $\mathrm{HO}_{\mathrm{M}}-\mathrm{NiO} / \mathrm{Cu}$, it presents the best performance. But on $\mathrm{HO}_{\mathrm{H}^{-}} \mathrm{NiO} / \mathrm{Cu}$, the $\mathrm{OH}^{-}$coverage seems too high to expose 
the rich active $\mathrm{NiO}$ sites for reaction. Meanwhile, this $53 \%$ coverage of $-\mathrm{OH}$ hardly optimizes the electronic configurations of catalysts structures, producing relatively inferior performance $\left(52 \mathrm{mV}\right.$ at $\left.10 \mathrm{mV} \mathrm{cm}^{-2}\right)$.
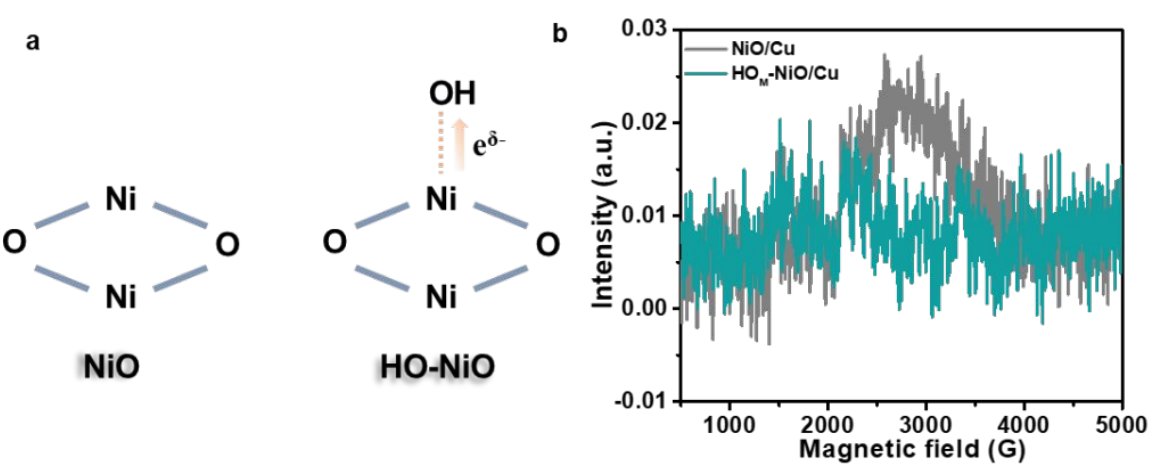

Figure S18. a, The diagram showing that additional hydroxylation deprives the electrons of Ni metal. b, EPR spectra (measured at $77 \mathrm{~K}$ ) of $\mathrm{NiO} / \mathrm{Cu}$ and $\mathrm{HO}_{\mathrm{M}}-\mathrm{NiO} / \mathrm{Cu}$. Even though our EPR measurement was conducted at strict conditions $(77 \mathrm{~K})$, no obvious symmetric peaks singles belonging to oxygen vacancies can be noticed from obtained spectra. This suggests our method (annealing $400{ }^{\circ} \mathrm{C}$ at vacuum condition for 3 hours in Ar gas) is efficient to produce the defect-free nanomaterial with oxides/metal interface.
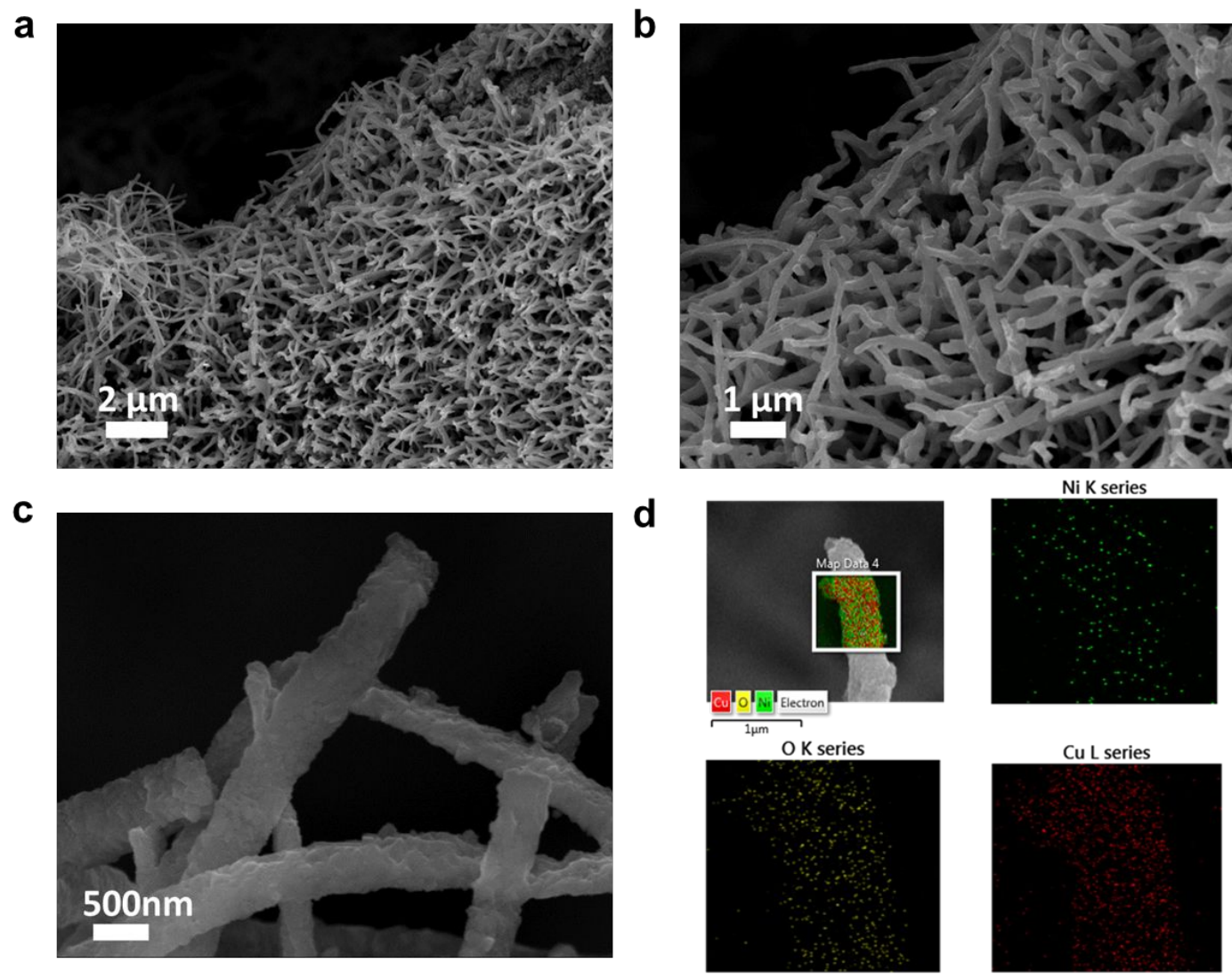

Figure S19. a-c, SEM images of $\mathrm{HO}_{\mathrm{L}}-\mathrm{NiO} / \mathrm{Cu}$. d, Corresponding elemental mappings. 

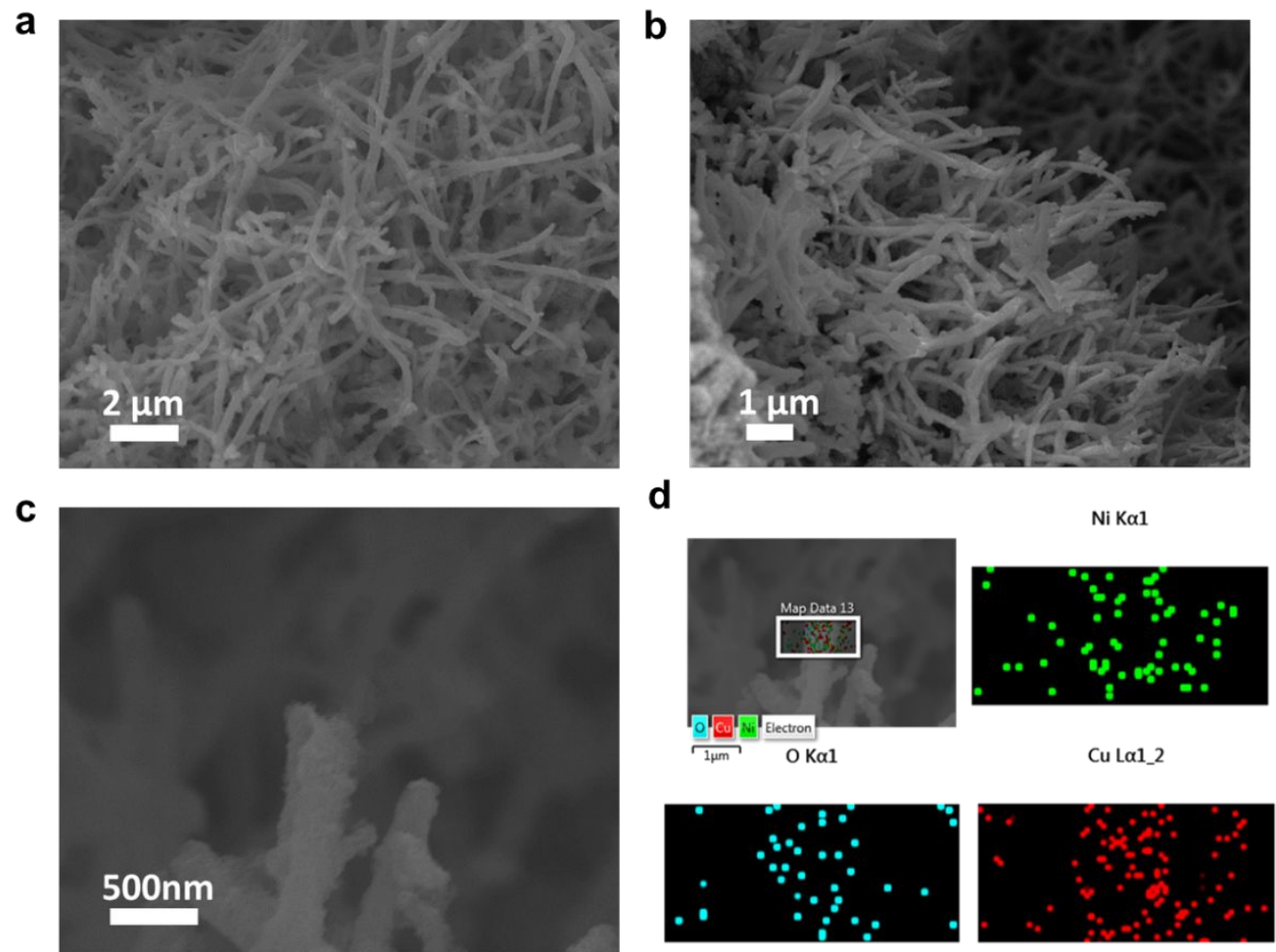

Figure S20. a-c, SEM images of $\mathrm{HO}_{\mathrm{H}}-\mathrm{NiO} / \mathrm{Cu}$. d, Corresponding elemental mappings. 

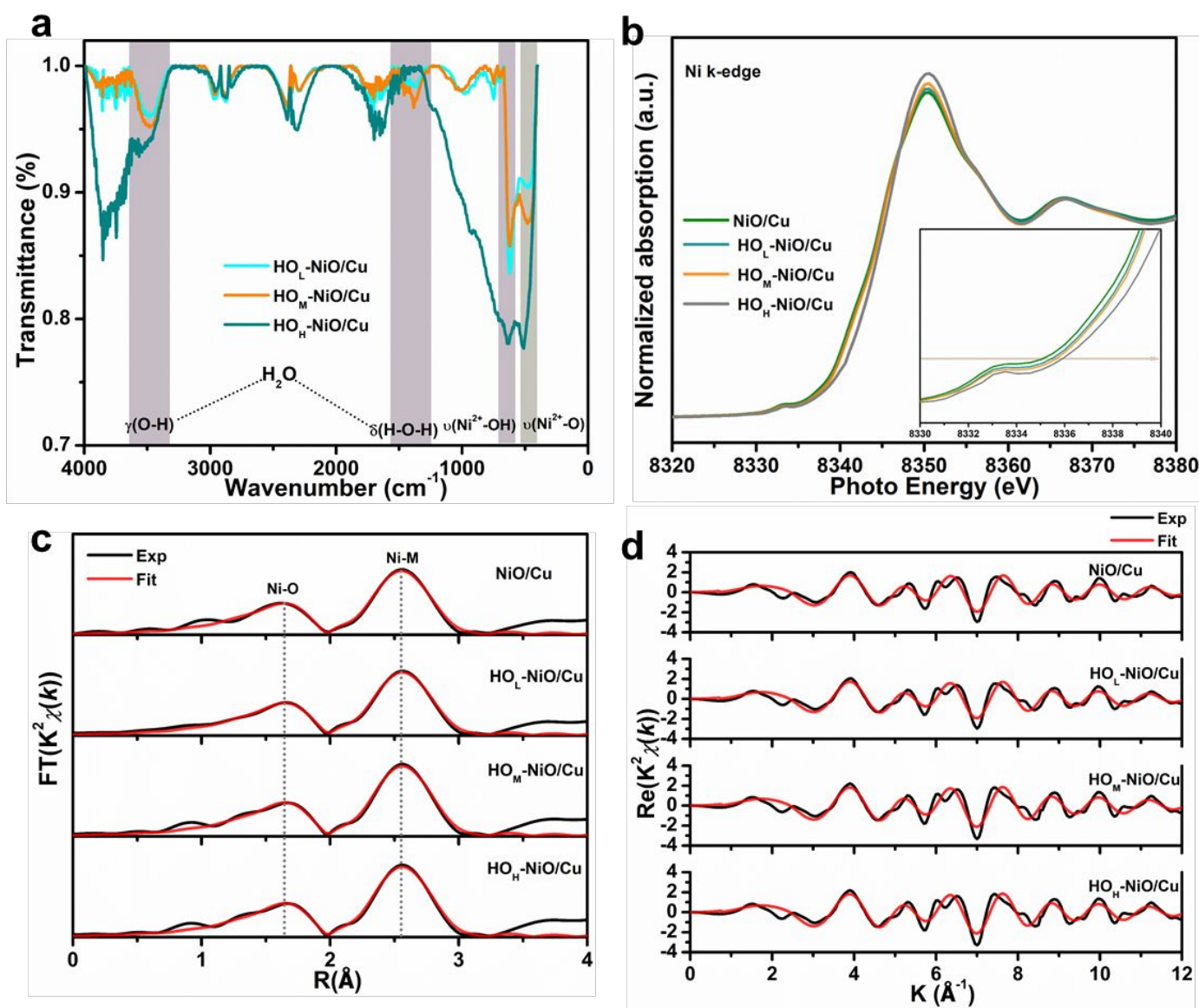

e

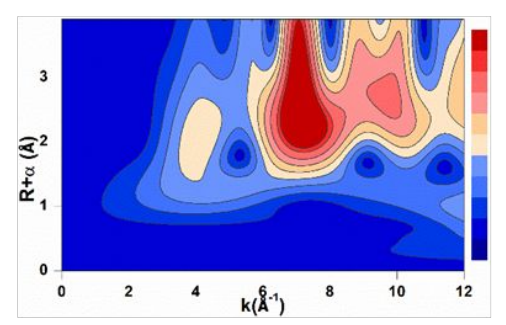

f
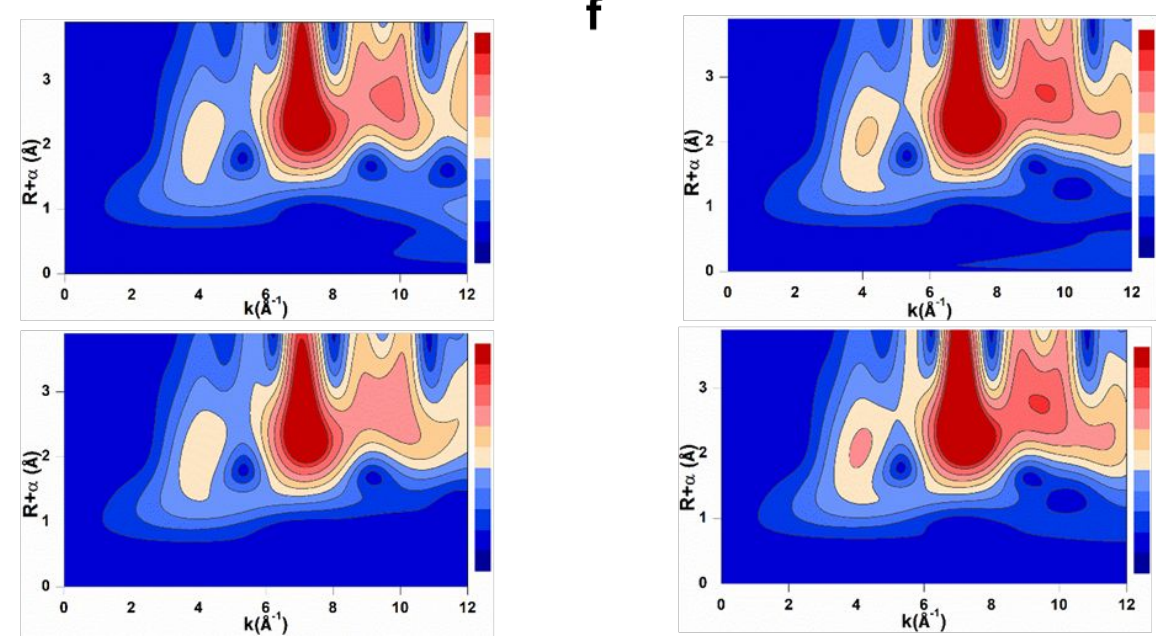

Figure S21. a-d FT-IR spectra, normalized Ni k-edge X-ray absorption spectra (XANES), EXAFS $k^{2} \chi(k)$ Fourier transform (FT) spectra, and fitting paths of catalysts. e, WT-EXAFS of $\mathrm{Ni}$ in $\mathrm{NiO} / \mathrm{Cu}, \mathrm{HO}_{\mathrm{L}}-\mathrm{NiO} / \mathrm{Cu}, \mathrm{HO}_{\mathrm{M}}-\mathrm{NiO} / \mathrm{Cu}$, and $\mathrm{HO}_{\mathrm{H}}-\mathrm{NiO} / \mathrm{Cu}$. The chemical states of $\mathrm{Ni}$ in $\mathrm{HO}_{\mathrm{L}}-\mathrm{NiO} / \mathrm{Cu}$ were similar to those of $\mathrm{NiO} / \mathrm{Cu}$, consistent with XPS and FT-IR results. $\mathrm{HO}_{\mathrm{H}}-\mathrm{NiO} / \mathrm{Cu}$ showed more scattering of $\mathrm{Ni}-\mathrm{O}$ than $\mathrm{HO}_{\mathrm{M}^{-}}$ $\mathrm{NiO} / \mathrm{Cu}$, which is another indicator of more hydroxyl adsorption on $\mathrm{Ni}$ atoms. 


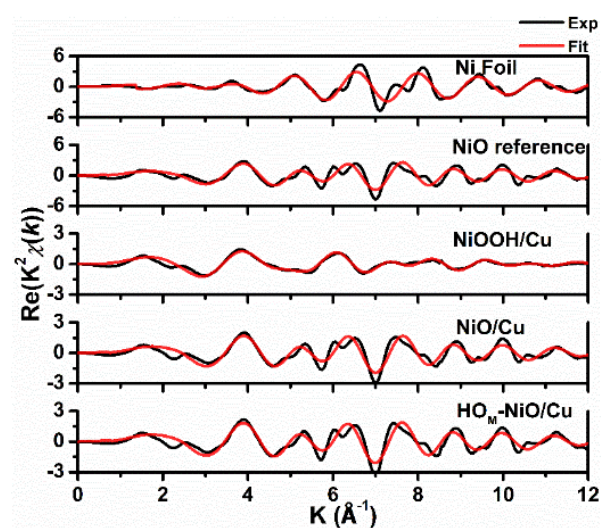

Figure S22. Fitting paths of catalysts with $\mathrm{Ni}$ foil and standard $\mathrm{NiO}$ spectra as references.
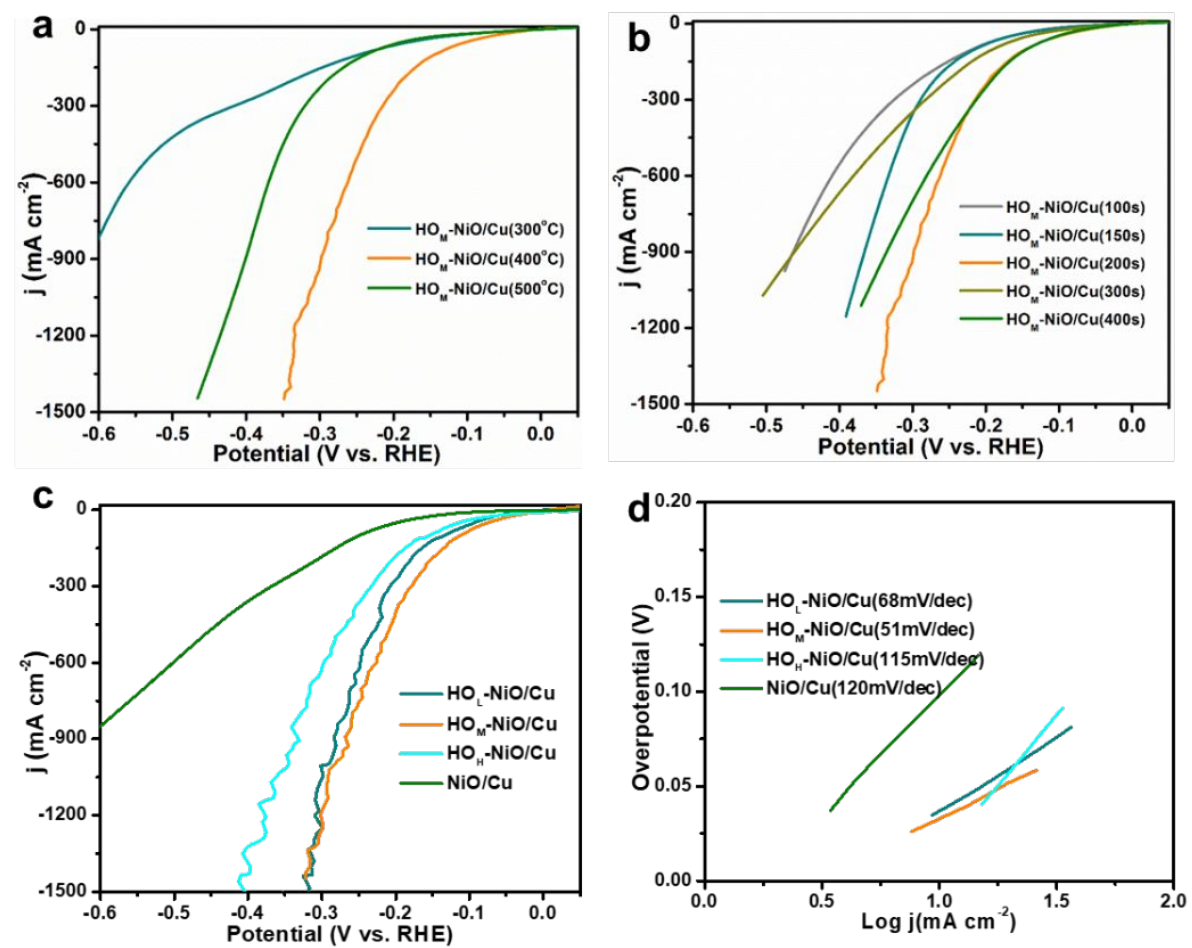

Figure S23. a,b, HER performance of $\mathrm{HO}_{\mathrm{M}}-\mathrm{NiO} / \mathrm{Cu}$ samples prepared by using various annealing temperatures and electrodeposition periods. c,d, Performance comparisons, including LSV and Tafel slopes, among $\mathrm{HO}_{\mathrm{L}}-\mathrm{NiO} / \mathrm{Cu}, \mathrm{HO}_{\mathrm{M}^{-}} \mathrm{NiO} / \mathrm{Cu}$, and $\mathrm{HO}_{\mathrm{H}^{-}}$ $\mathrm{NiO} / \mathrm{Cu}$. 

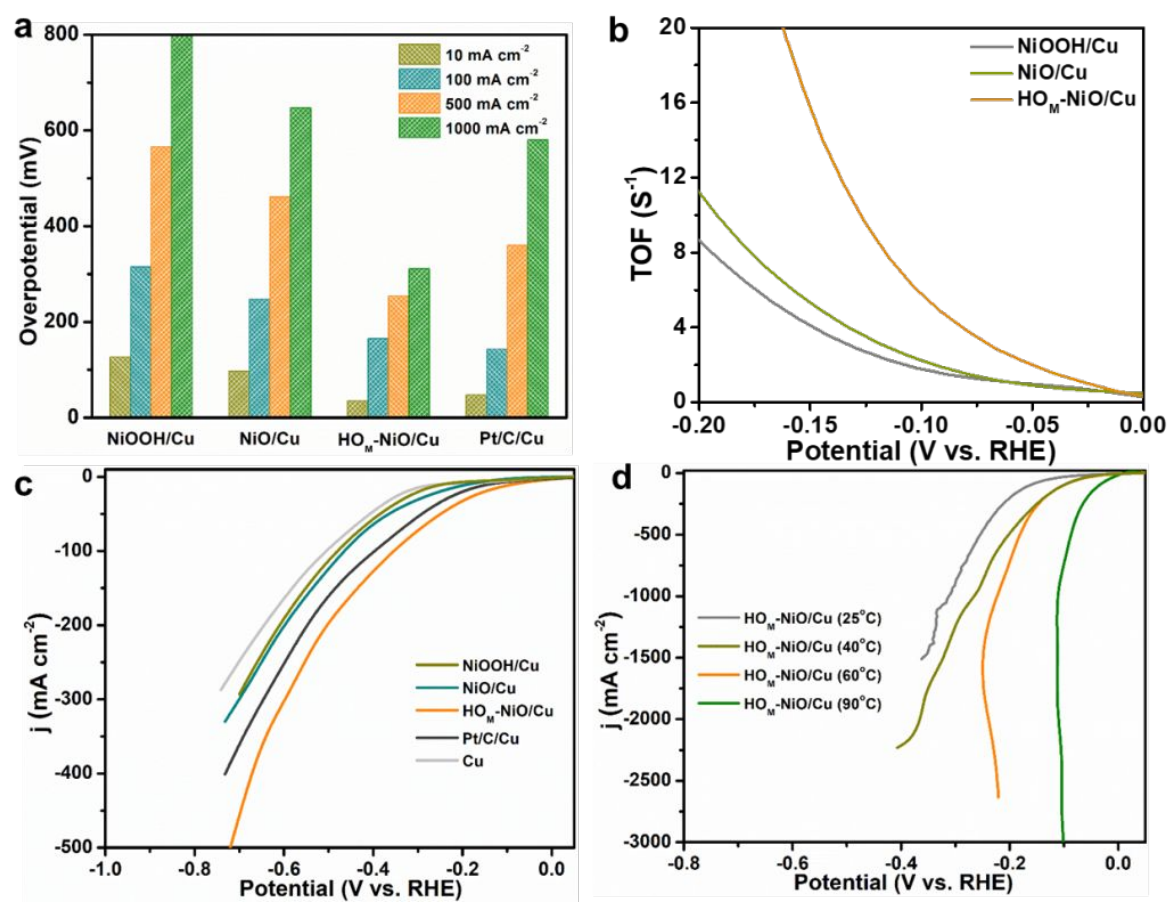

Figure S24. a,b Summary of HER performance and Turnover frequency (TOF) among catalysts in $1 \mathrm{M} \mathrm{KOH}$. LSV of catalysts in PBS solution. c, LSVs of $\mathrm{HO}_{\mathrm{M}}-\mathrm{NiO} / \mathrm{Cu}$ tested at various electrolyzer cell temperatures.
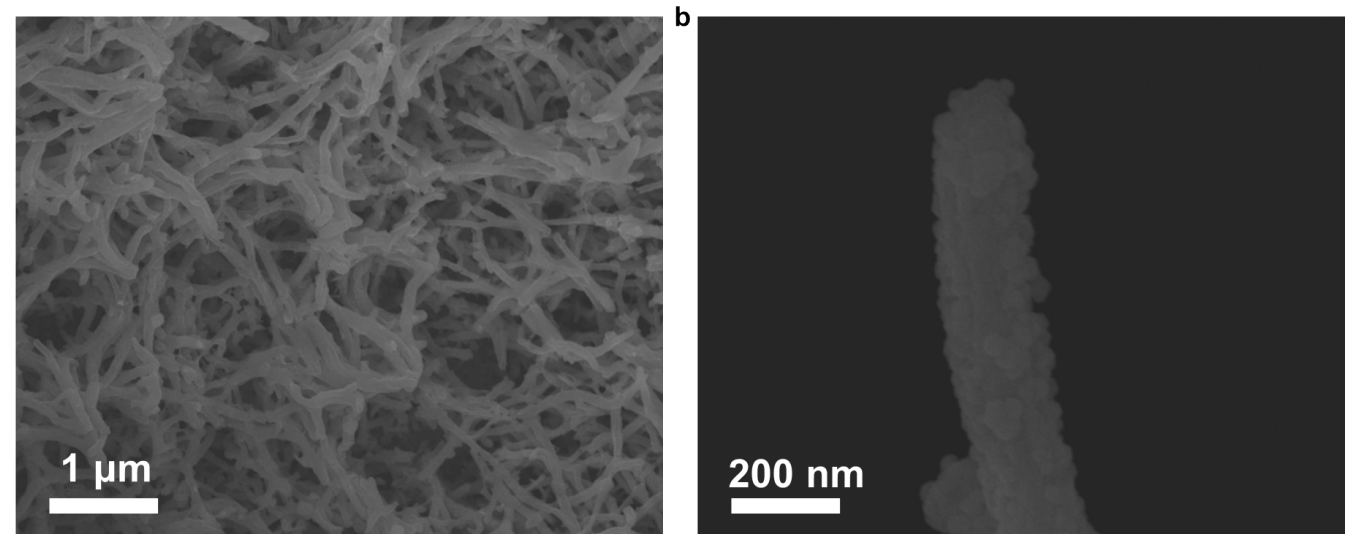

Figure S25. a,b, SEM images of $\mathrm{HO}_{\mathrm{M}}-\mathrm{NiO} / \mathrm{Cu}$ after $3000 \mathrm{CV}$ cycles of HER. 

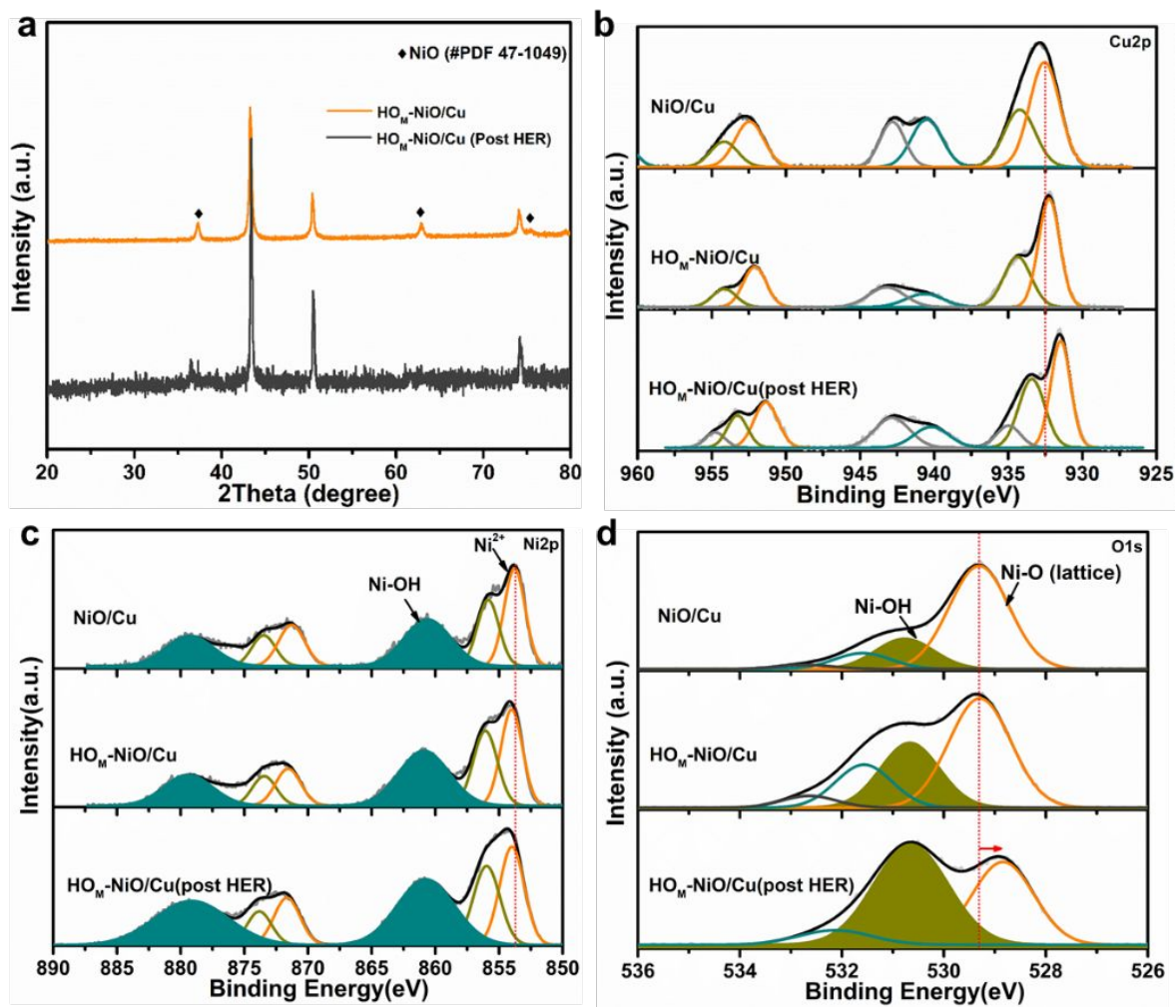

Figure S26. a-d, XRD, Cu2p, Ni2p, and O1s XPS spectra of $\mathrm{HO}_{\mathrm{M}^{-}} \mathrm{NiO} / \mathrm{Cu}$ after 3000 $\mathrm{CV}$ cycles of HER. Only $\mathrm{NiO}$ and $\mathrm{Cu}$ crystalline phases showed in XRD after the reaction. In $\mathrm{Cu} 2 \mathrm{p}$ XPS spectra, $\mathrm{Cu}$ showed lowered oxidation states, indicating that $\mathrm{Cu}$ as hydrogen evolution sites conduct the electrons towards adsorbed hydrogen and undergoes further reduction during a while. The chemical states of $\mathrm{NiO}$ still remain unchanged after the reaction but the ratio of the Ni-OH binding component increases, confirming that $\mathrm{Ni}$ is the water adsorption and dissociation sites. Meanwhile, the $\mathrm{O}-\mathrm{M}$ bonding shifts to lower energy, which is also an indicator of decreased oxophilicity due to an electron-rich configuration. 

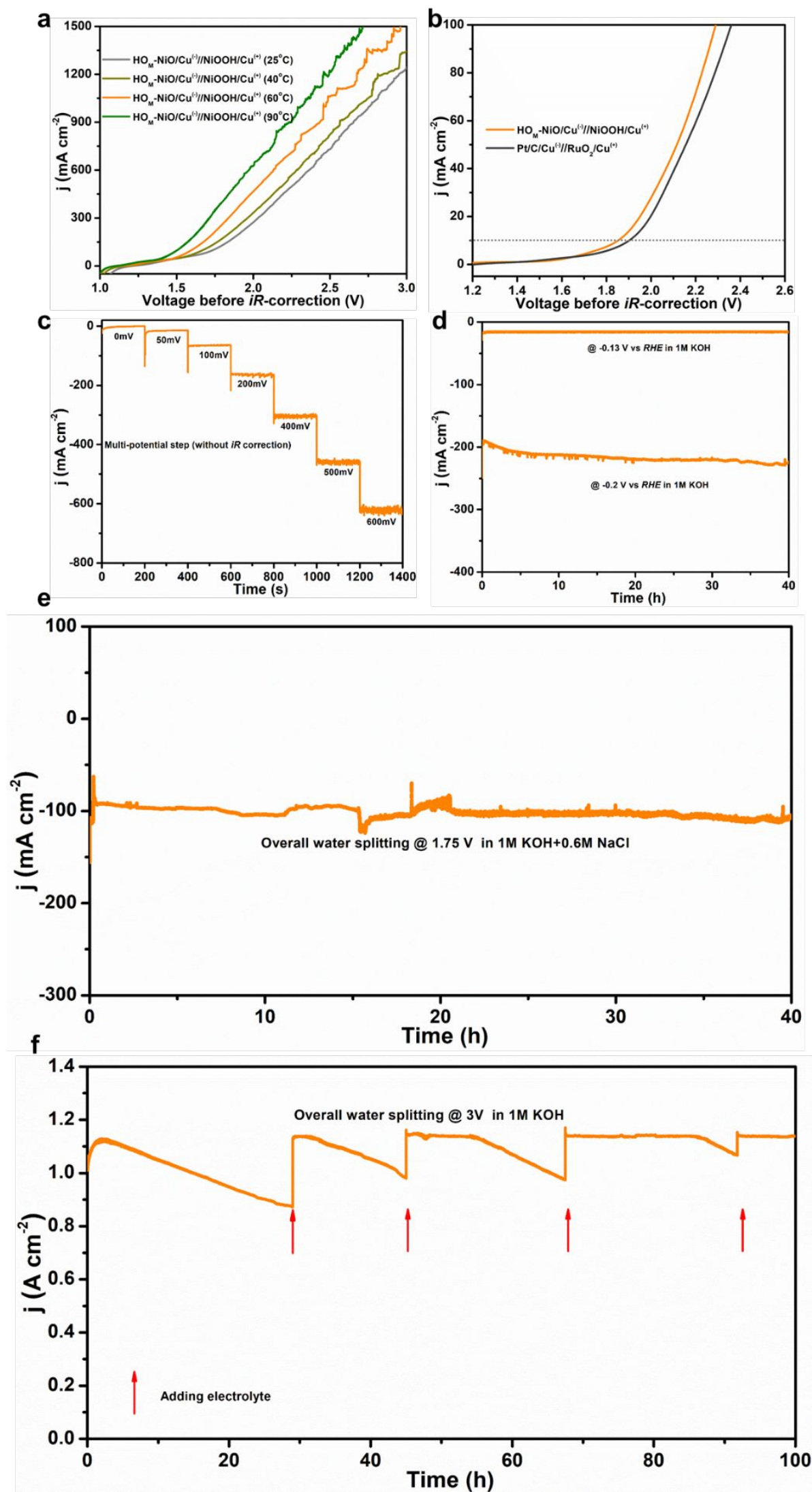

Figure S27. a,b, Overall water splitting performance before $\mathrm{i} R$ correction of the electrode pair of $\mathrm{HO}_{\mathrm{M}}-\mathrm{NiO} / \mathrm{Cu} / \mathrm{NiOOH} / \mathrm{Cu}$ in alkaline and $\mathrm{PBS}$, showing increasingly thermally favorable kinetics with increasing electrolyzer temperature. c,d, 
Multipotential stepped HER performance and durability of $\mathrm{HO}_{\mathrm{M}}-\mathrm{NiO} / \mathrm{Cu}$. e, Stability of overall water splitting at $100 \mathrm{~mA} \mathrm{~cm}^{-2}$ in simulated seawater. $\mathrm{f}$, Stability of overall water splitting at an ultrahigh current density of $1 \mathrm{~A} \mathrm{~cm}^{-2}$ in $1 \mathrm{M} \mathrm{KOH}$.
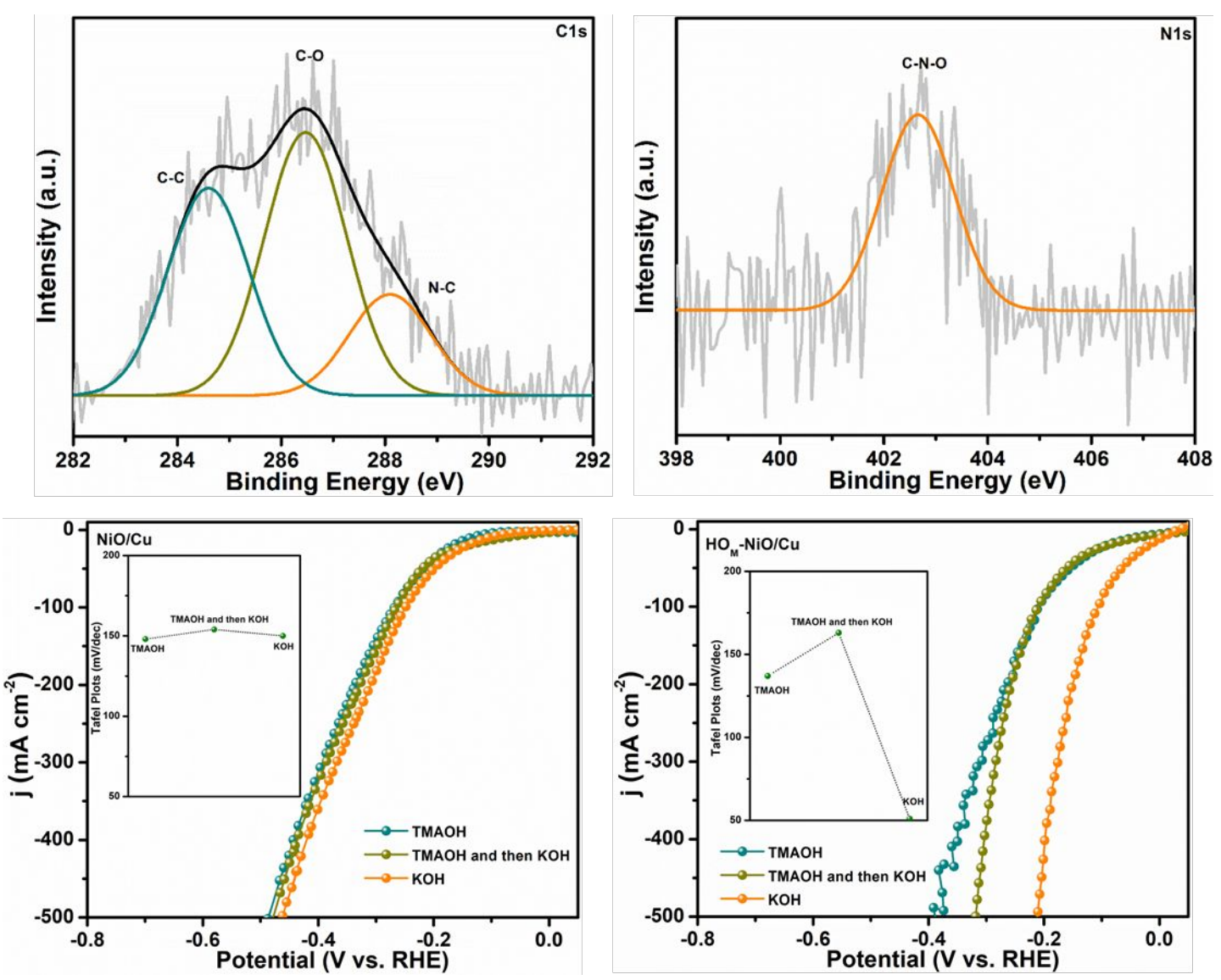

Figure S28. a,b, C1s and N1s XPS spectra were used to analyze $\mathrm{HO}_{\mathrm{M}}-\mathrm{NiO} / \mathrm{Cu}$ surface changes after pretreating for $2 \mathrm{~h}$ in $1 \mathrm{M}$ tetramethylammonium hydroxide (TMAOH). The tetramethylammonium cation $\left(\mathrm{TMA}^{+}\right)$as a chemical probe can always track $\mathrm{O}$ species because of its specific interaction with negative oxygenated species. ${ }^{11-14}$ The $\mathrm{C}-\mathrm{O}$ and $\mathrm{C}-\mathrm{N}-\mathrm{O}$ bondings prove that interaction between TMAOH and surficial $\mathrm{OH}^{-}$ of $\mathrm{HO}_{\mathrm{M}}-\mathrm{NiO} / \mathrm{Cu}$ occurs as intended, blocking the positive effect on $\mathrm{HER}$, which extrinsic $\mathrm{OH}^{-}$imparts to $\mathrm{NiO} / \mathrm{Cu}$. c,d, HER results of $\mathrm{NiO}$ and $\mathrm{HO}_{\mathrm{M}}-\mathrm{NiO} / \mathrm{Cu}$ pretreated with TMAOH. TMAOH did not worsen the performance of $\mathrm{NiO}$, indicating the lack of surficial $\mathrm{OH}^{-}$on $\mathrm{NiO} / \mathrm{Cu}$. In stark contrast, the case of $\mathrm{HO}_{\mathrm{M}^{-}} \mathrm{NiO} / \mathrm{Cu}$ performed lowered activities; this indicates that $\mathrm{TMA}^{+}$strongly binds to the $\mathrm{HO}_{\mathrm{M}}-\mathrm{NiO} / \mathrm{Cu}$ surface through the in situ attached negative hydroxyl during the electrochemically assisted functionalization process. 

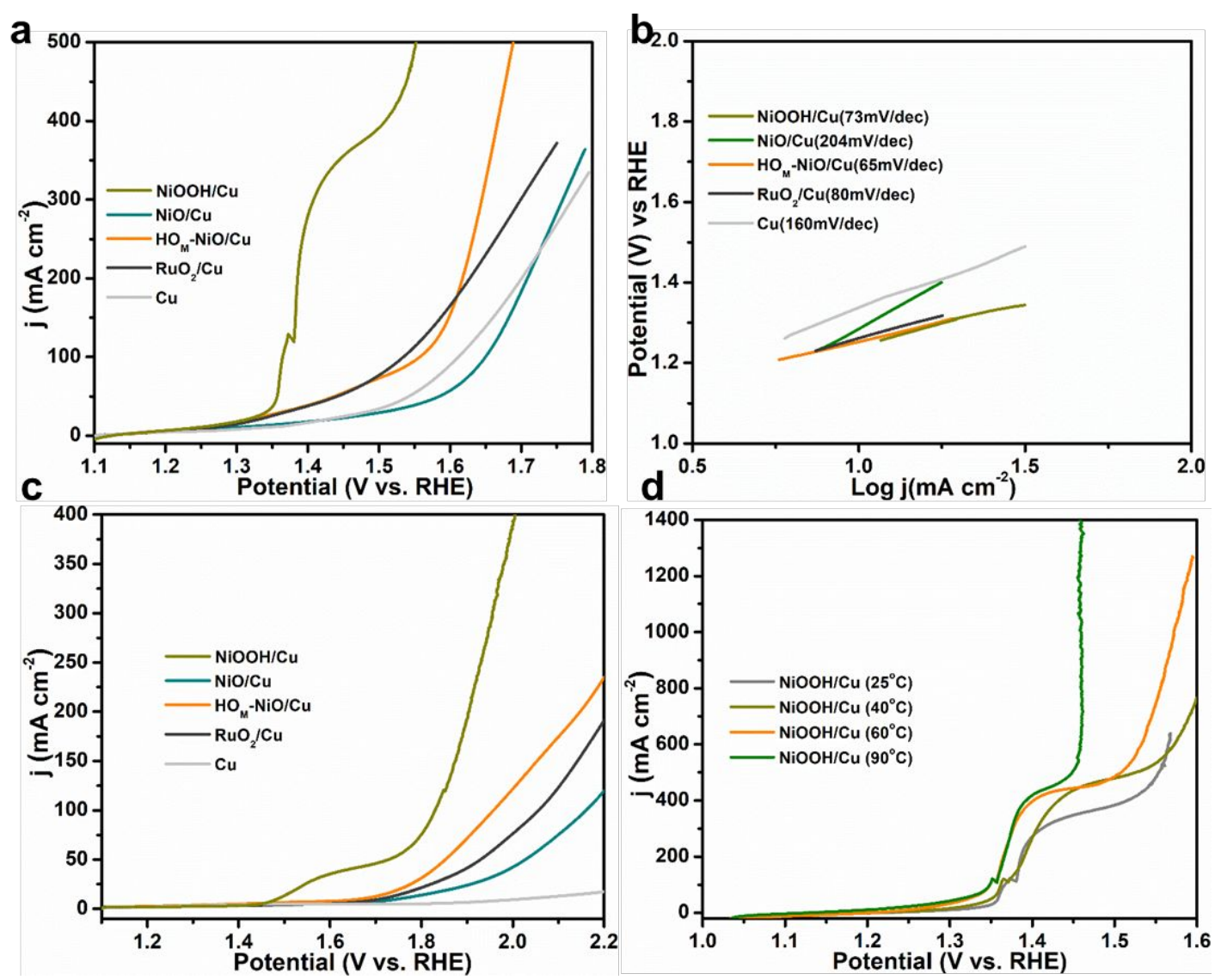

Figure S29. a,b, OER LSV and Tafel slopes of catalysts in $1 \mathrm{M} \mathrm{KOH}$. c, OER LSV of catalysts in PBS. NiOOH showed the best OER performance. d, OER performance of $\mathrm{NiOOH}$ under various electrolyzer temperatures. 

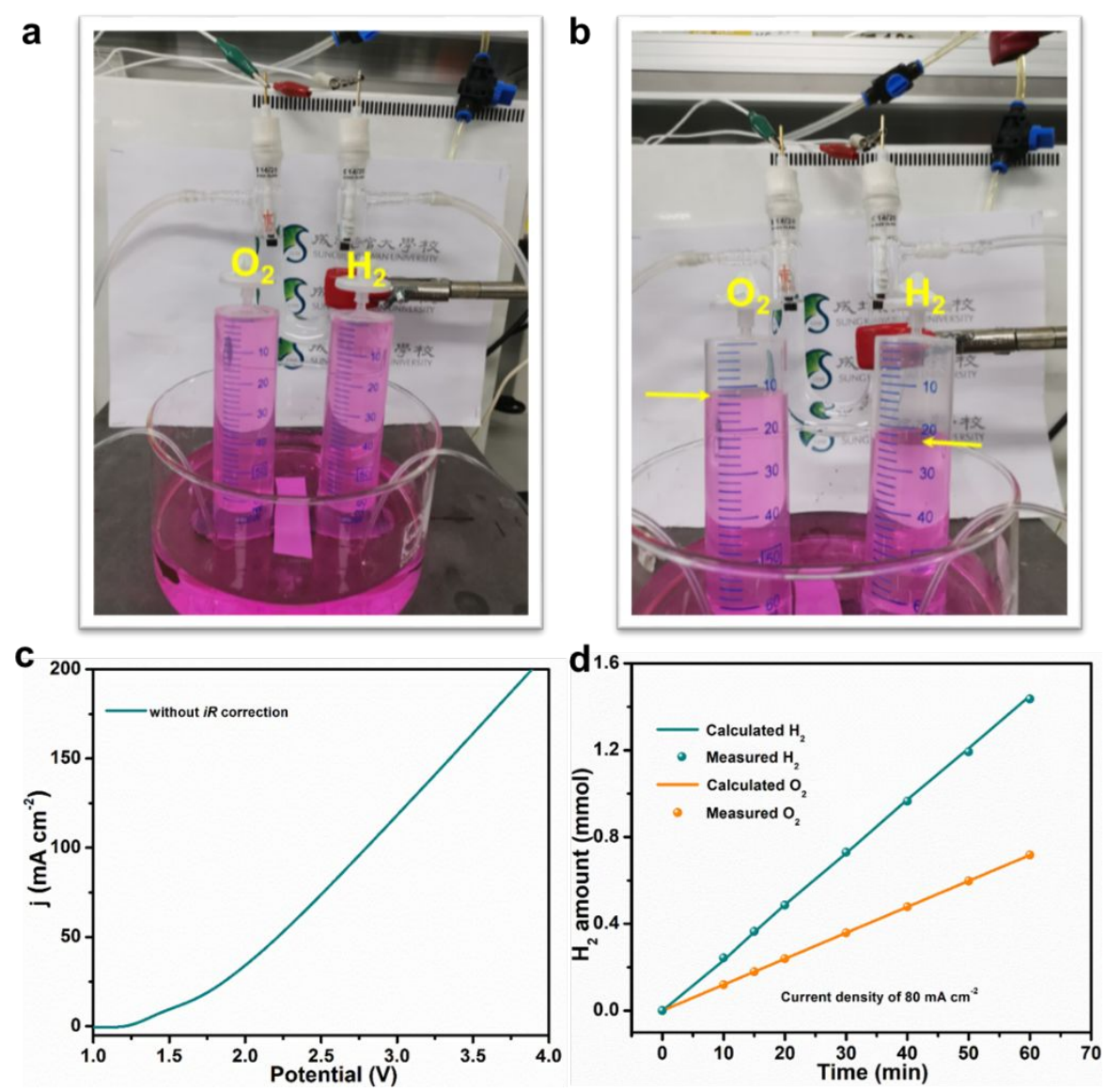

Figure S30. a-c, Homemade equipment for collecting evolved gas using a U-shape electrolyzer, and LSV of during overall water splitting, logo was granted by correct source. $\mathrm{d}, \mathrm{H}_{2}$ and $\mathrm{O}_{2}$ emission amounts under the current density of $80 \mathrm{~mA} \mathrm{~cm}$. 
a
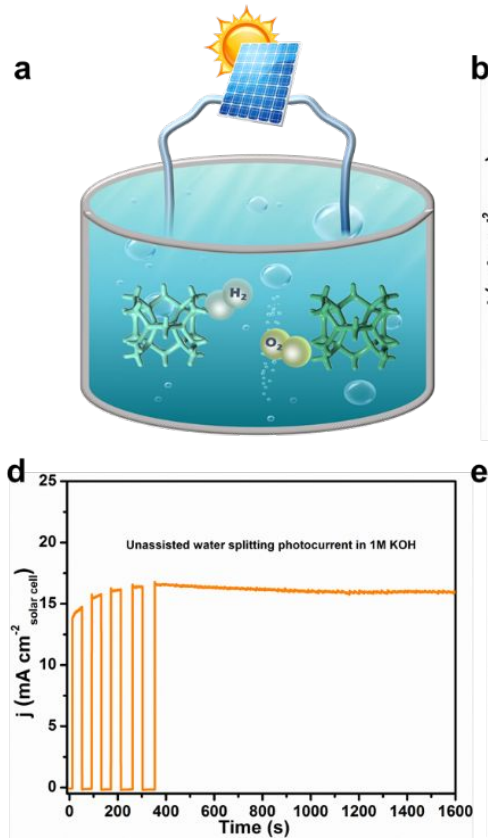

b
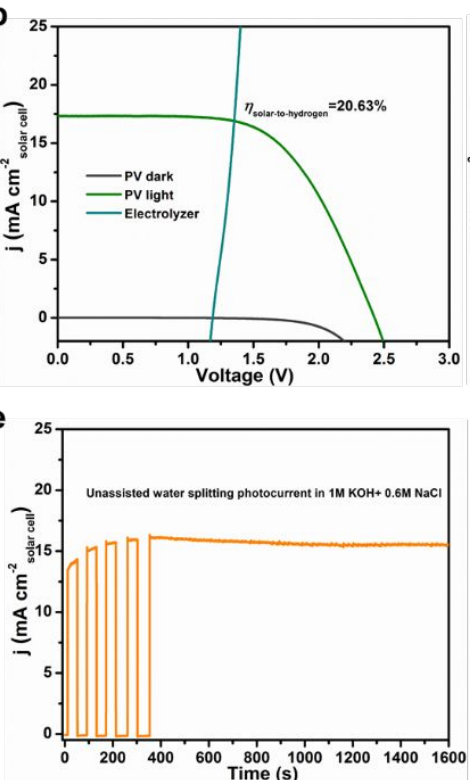
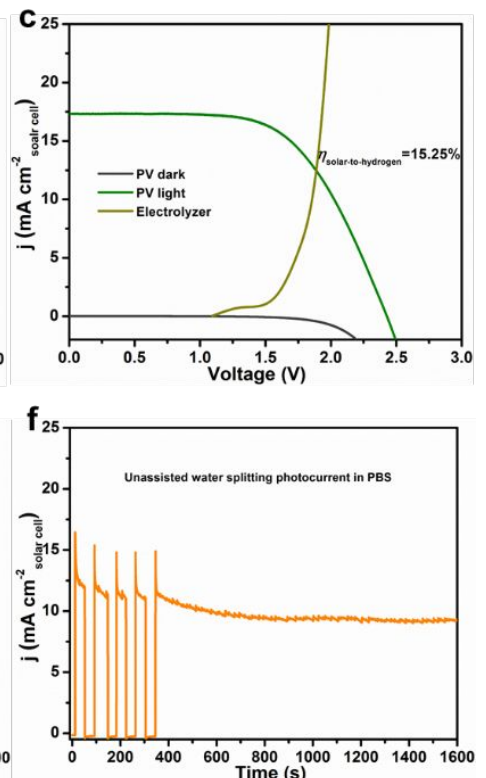

Figure S31. a, Mechanism of homemade equipment for solar-cell-driven overall water splitting. b,c, Current density-potential curve $(J-V)$ of the electrolyzer and two perovskite tandem cells (photo shown in inset) under dark and simulated AM 1.5 G 100 $\mathrm{mW} \cdot \mathrm{cm}^{-2}$ illumination in simulated seawater and PBS. The illuminated surface area of the perovskite cell was $9.24 \mathrm{~cm}^{2}$ total, and the catalyst electrode areas were $1 \mathrm{~cm}^{2}$ each (geometric). d-f, Unassisted water splitting photocurrents in (d) $1 \mathrm{M} \mathrm{KOH}$, (e) simulated seawater, and (f) PBS.

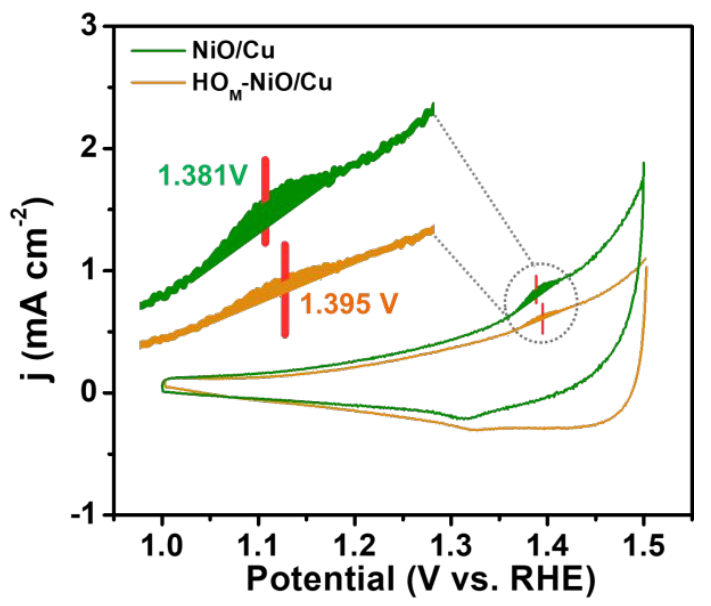

Figure S32. CV curves obtained at a scan rate of $1 \mathrm{mV} / \mathrm{s}$.

The obtained $\mathrm{CV}$ curves present distinct redox peaks on $\mathrm{NiO} / \mathrm{Cu}$ and $\mathrm{HO}_{\mathrm{M}}-\mathrm{NiO} / \mathrm{Cu}$ electrodes. The $\mathrm{NiO} / \mathrm{Cu}$ not only has a lower peak position $(1.381 \mathrm{~V})$ but also a larger $\mathrm{HO}^{*}$ adsorption peaks area compared to the hydroxylated catalyst surface $\left(\mathrm{HO}_{\mathrm{M}^{-}}\right.$ $\mathrm{NiO} / \mathrm{Cu}$, a peak position of $1.395 \mathrm{~V}$ ). Since the position and area of anodic redox peak respectively reflect the binding strength and ability of the $\mathrm{HO}^{*}$ intermediate ${ }^{15-17}$, herein the affinity or oxophilicity of $\mathrm{HO}_{\mathrm{M}^{-}} \mathrm{NiO} / \mathrm{Cu}$ towards $\mathrm{HO}^{*}$ is weakened. 

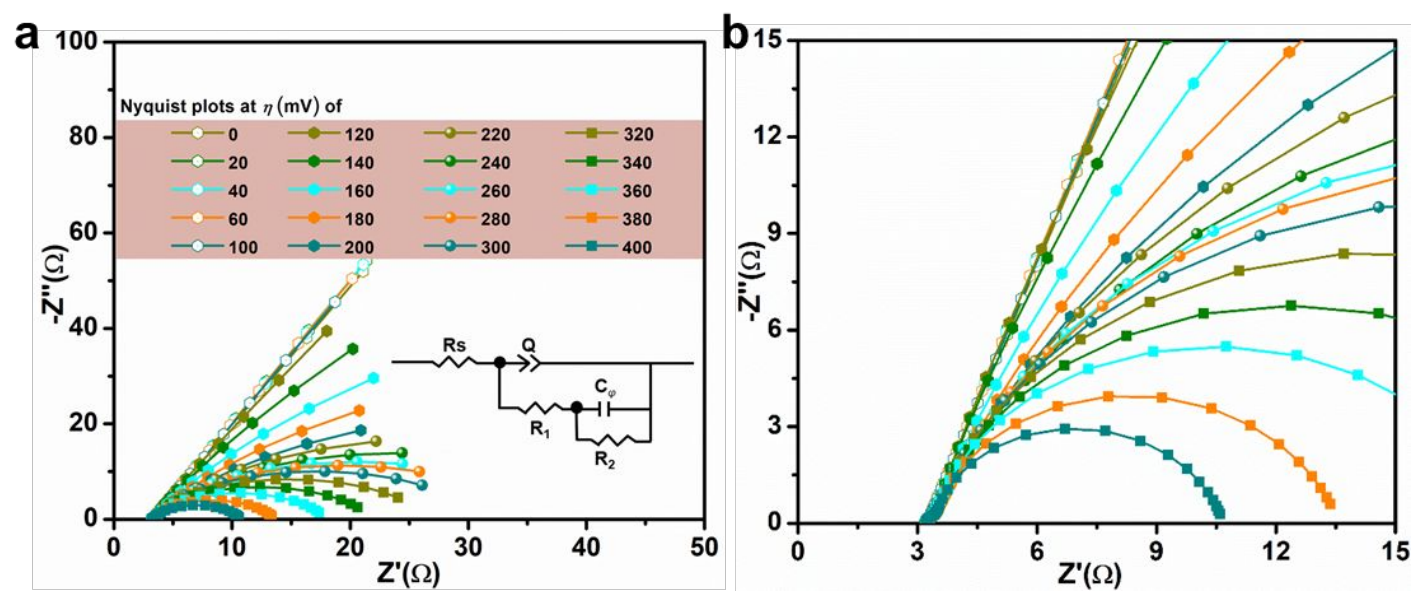

Figure S33. a,b, (a) Nyquist plots for Cu catalyst in $1 \mathrm{M} \mathrm{KOH}$ at various overpotentials and (b) zoomed-in views, with inset showing the equivalent circuit used for simulation. The fitting parameters are summarized in Table S2. ${ }^{18-20}$
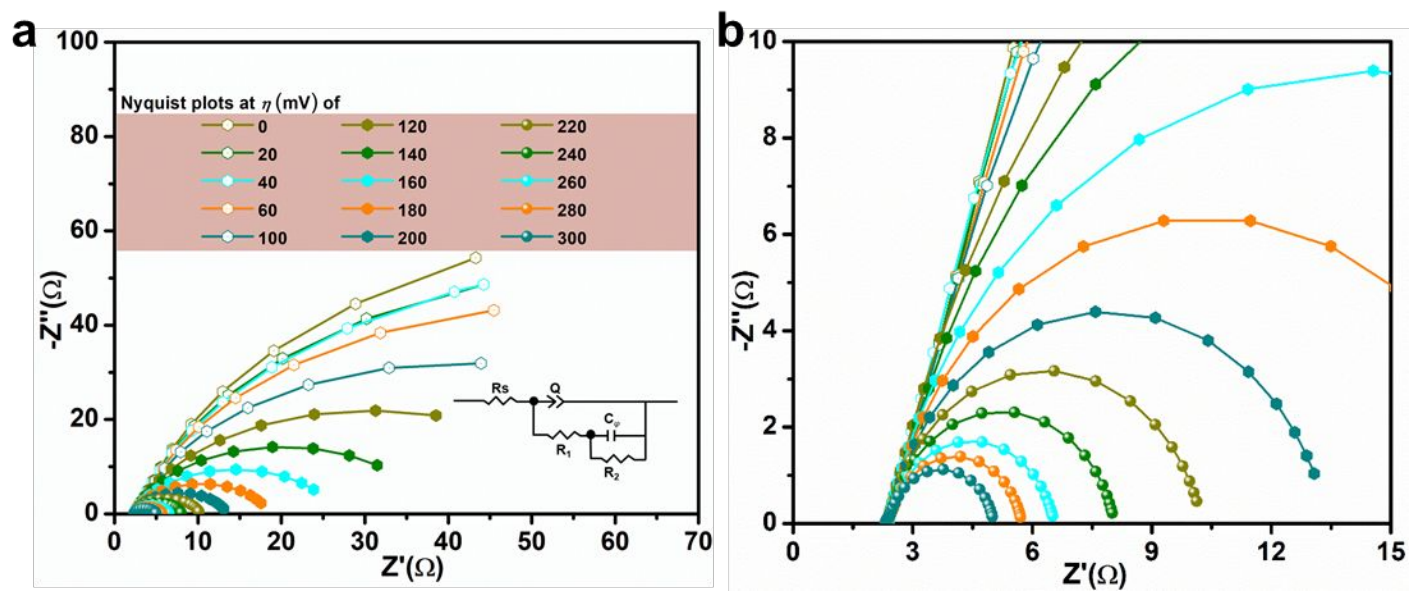

Figure S34. a,b, (a) Nyquist plots for $\mathrm{NiOOH} / \mathrm{Cu}$ catalyst in $1 \mathrm{M} \mathrm{KOH}$ at various overpotentials and (b) zoomed-in views, with inset showing the equivalent circuit used for simulation. The fitting parameters are summarized in Table S3. 

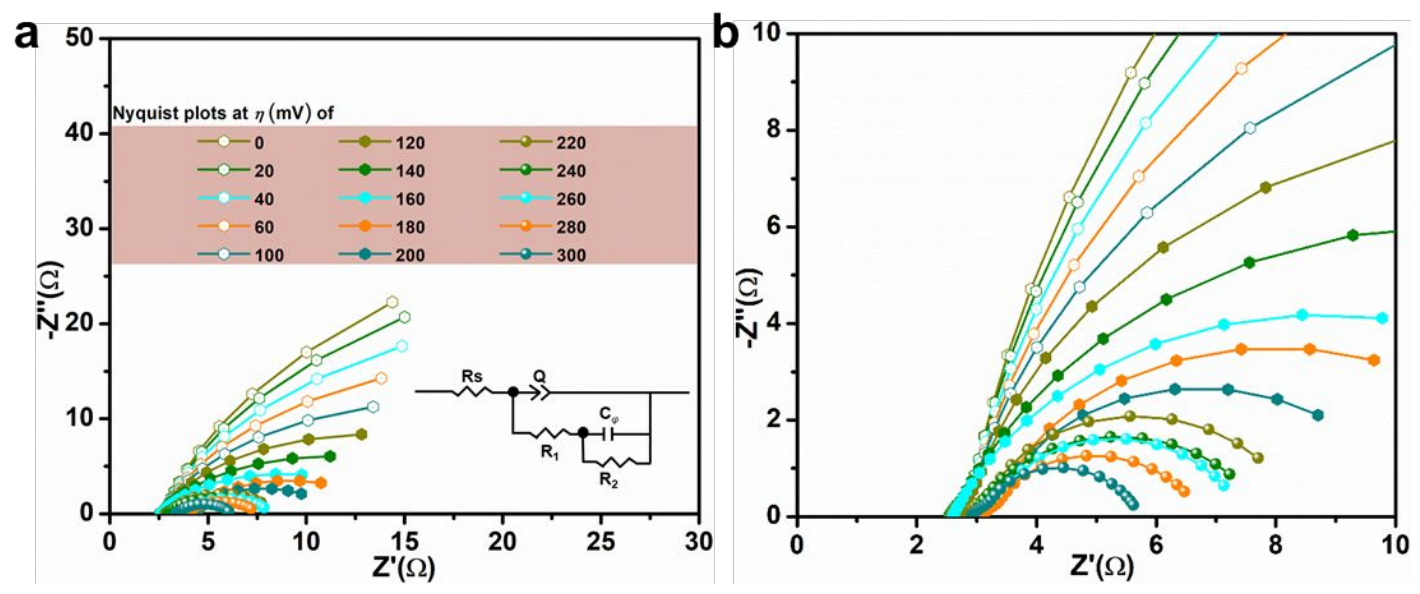

Figure S35. a,b, (a) Nyquist plots for $\mathrm{NiO} / \mathrm{Cu}$ catalyst in $1 \mathrm{M} \mathrm{KOH}$ at various overpotentials and (b) zoomed-in views, with inset showing the equivalent circuit used for simulation. The fitting parameters are summarized in Table S4.
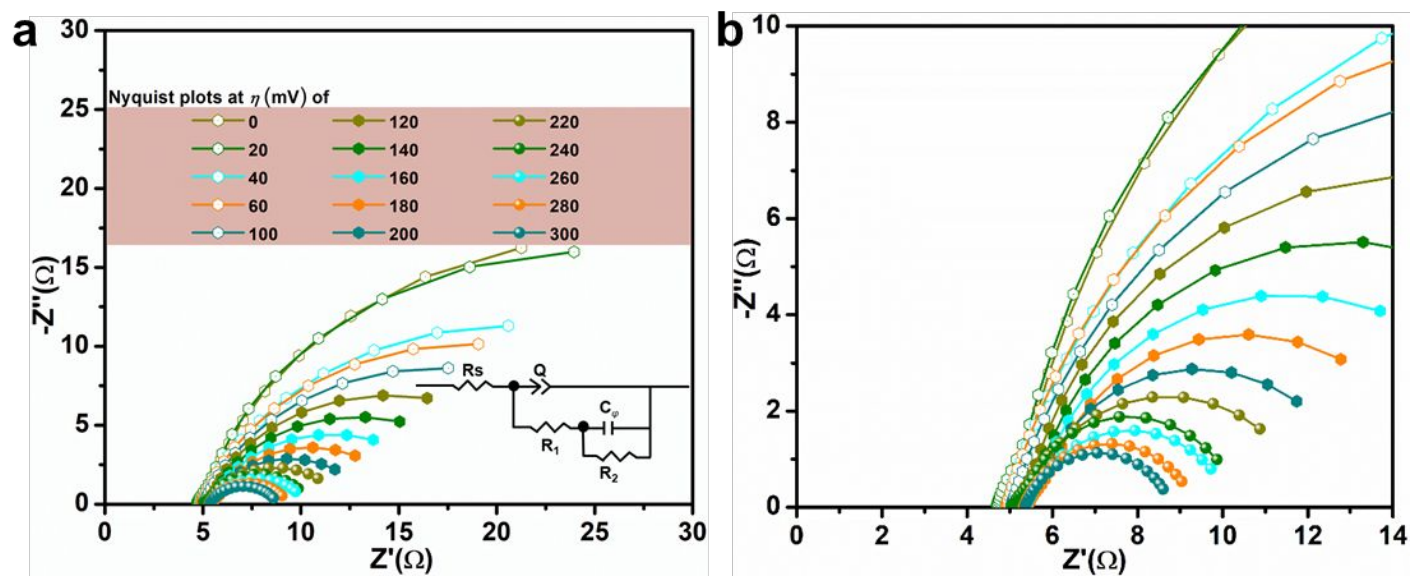

Figure S36. a,b, (a) Nyquist plots for $\mathrm{HO}_{\mathrm{L}}-\mathrm{NiO} / \mathrm{Cu}$ catalyst in $1 \mathrm{M} \mathrm{KOH}$ at various overpotentials and (b) zoomed-in views, with inset showing the equivalent circuit used for simulation. The fitting parameters are summarized in Table S5. 

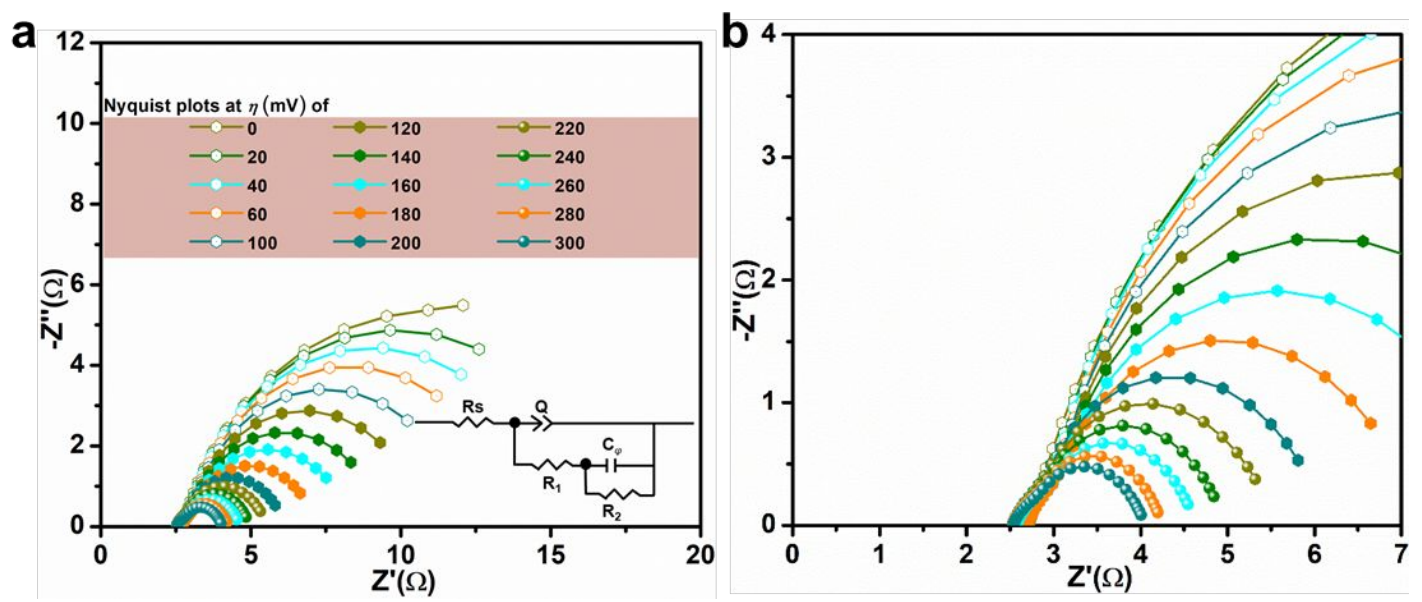

Figure S37. a,b, (a) Nyquist plots for $\mathrm{HO}_{\mathrm{M}}-\mathrm{NiO} / \mathrm{Cu}$ catalyst in $1 \mathrm{M} \mathrm{KOH}$ at various overpotentials and (b) zoomed-in views, with inset showing the equivalent circuit used for simulation. The fitting parameters are summarized in Table S6.
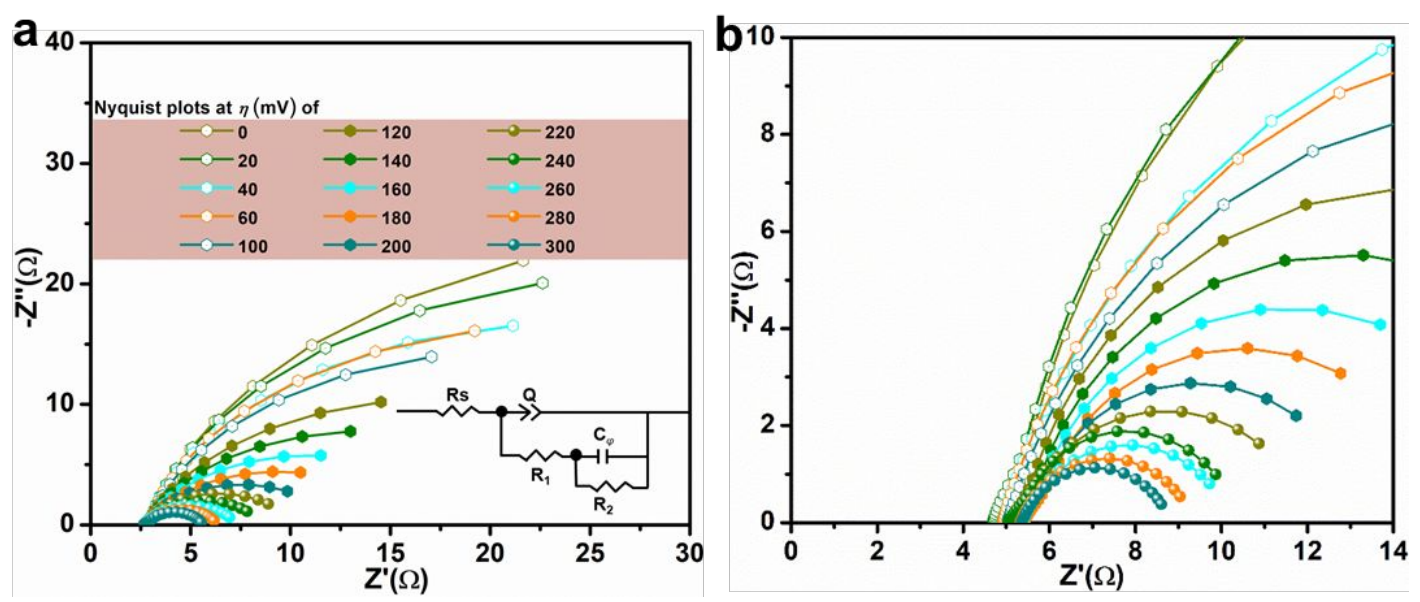

Figure S38. a,b, (a) Nyquist plots for $\mathrm{HO}_{\mathrm{H}}-\mathrm{NiO} / \mathrm{Cu}$ catalyst in $1 \mathrm{M} \mathrm{KOH}$ at various overpotentials and (b) zoomed-in views, with inset showing the equivalent circuit used for simulation. The fitting parameters are summarized in Table S7. 

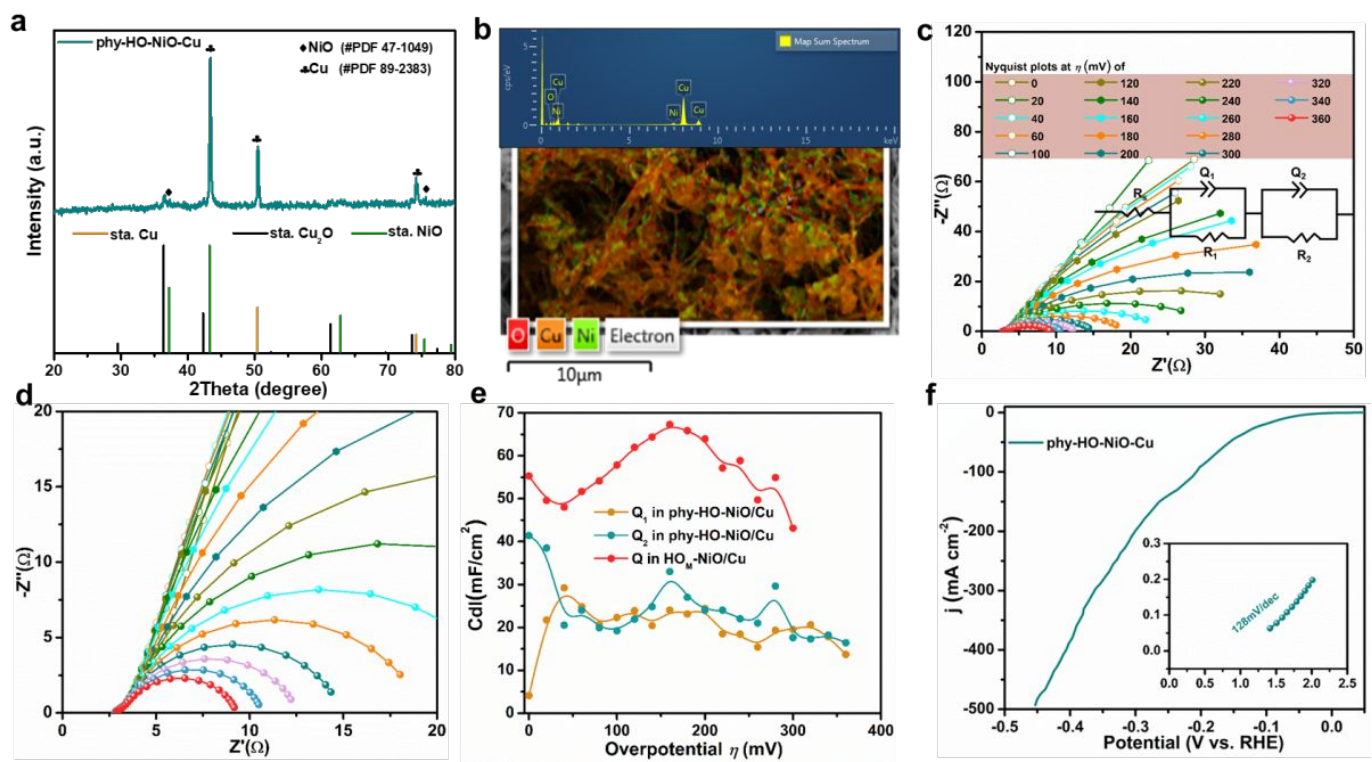

Figure S39. a,b XRD and SEM elemental mapping of phy-HO-NiO/Cu, insets in a and c are XRD and an elemental spectrum from SEM, respectively. c,d Nyquist plots for phy-HO-NiO/Cu catalyst in $1 \mathrm{M} \mathrm{KOH}$ at various overpotentials and zoomed-in views, with inset showing the equivalent circuit used for simulation. The fitting parameters are summarized in Table S8. e, Comparison of Q values of phy-HO-NiO/Cu and that of $\mathrm{HO}_{\mathrm{M}}-\mathrm{NiO} / \mathrm{Cu}$ (from Tables S6 and S8). f, HER LSV and Tofel plot of phy-HO-NiO/Cu. For the positive effect of heterointerface, the phy-HO-NiO/Cu (physical loading HO$\mathrm{NiO}$ on $\mathrm{Cu}$ ) was prepared and compared. No heterointerface and only physical landing of $\mathrm{NiO}$ on $\mathrm{Cu}$ can be noticed. Then the electrochemical impedance spectroscopy (EIS) measurements and analysis were also conducted to study its structure-induced hydrogen spillover mechanism. As shown in Figure S34d,e, the phy-HO-NiO/Cu performs the different equivalent circuit diagram compared to $\mathrm{HO}_{M}-\mathrm{NiO} / \mathrm{Cu}$. Similarly, $\mathrm{R}_{\mathrm{s}}$ reflects the uncompensated solution resistance. $\mathrm{Q}$ is named as semi-infinite diffusion, general diffusion, and imperfect (leaking) capacitor, and is Cdl (double-layer capacitor) when $\mathrm{Q}-\mathrm{n}=1$. However, different $\mathrm{Q}_{1}$ and $\mathrm{Q}_{2}$ were shown here and represented two kinds of double-layer capacitance given by hydroxylated $\mathrm{NiO}$ and $\mathrm{Cu}$. Respectively, $\mathrm{R}_{1}$ and $\mathrm{R}_{2}$ correspond to their charge-transfer resistance. These separated $\mathrm{Q}_{1}$ and $\mathrm{Q}_{2}$ indicate that $\mathrm{NiO}$ and $\mathrm{Cu}$ play individual elements in the equivalent circuit diagram, wherein their contribution in the catalyzing process is standalone. This is an indicator of the absence of a relationship between $\mathrm{NiO}$ and $\mathrm{Cu}$ in phy- $\mathrm{HO}_{\mathrm{M}}-\mathrm{NiO} / \mathrm{Cu}$ but deduces the existence of heterointerface in our $\mathrm{HO}_{\mathrm{M}}-\mathrm{NiO} / \mathrm{Cu}$. In addition, the value of $\mathrm{Q}_{1}$ and $\mathrm{Q}_{2}$ is very small even compared to the capacitance value of $\mathrm{HO}_{\mathrm{M}}-\mathrm{NiO} / \mathrm{Cu}$ case (Table S8), representing its limited HER activity (Figure S34f). More importantly, in the case of phy- $\mathrm{HO}_{\mathrm{M}^{-}}$ $\mathrm{NiO} / \mathrm{Cu}$, no $\mathrm{C} \varphi$ component was fitted out, verifying that charge (majority is $\mathrm{H}^{*}$ ) adsorption behavior on the catalyst surface is possibly scarce and no hydrogen spillover mechanism proceed. It is credible that heterointerface can positively result in hydrogen spillover and improve the whole of HER kinetics. 

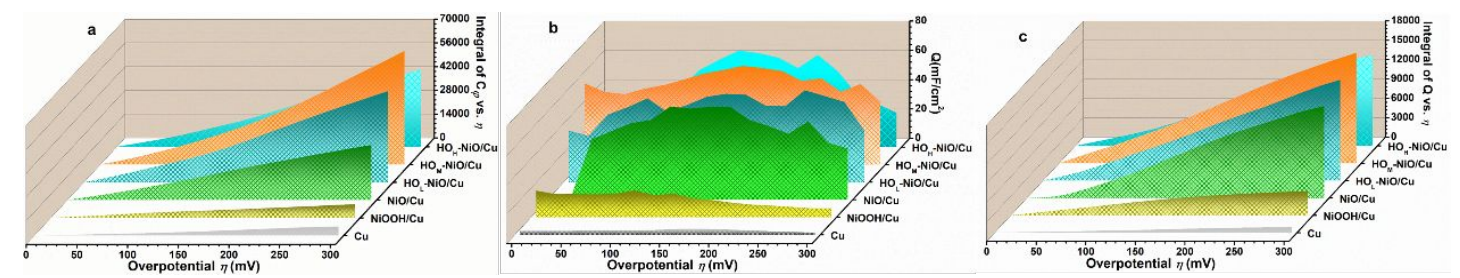

Figure S40. a Plots of integral of $\mathrm{C}_{\varphi} v s . \eta$ for catalysts in $1 \mathrm{M} \mathrm{KOH}, \mathrm{b} \mathrm{Cdl} v s . \eta$ and c the integral of $\mathrm{Cdl} v s . \eta$ for catalysts in $1 \mathrm{M} \mathrm{KOH}$. $\mathrm{HO}_{\mathrm{M}}-\mathrm{NiO} / \mathrm{Cu}$ shows the most abundant active surface area among the catalysts studied.

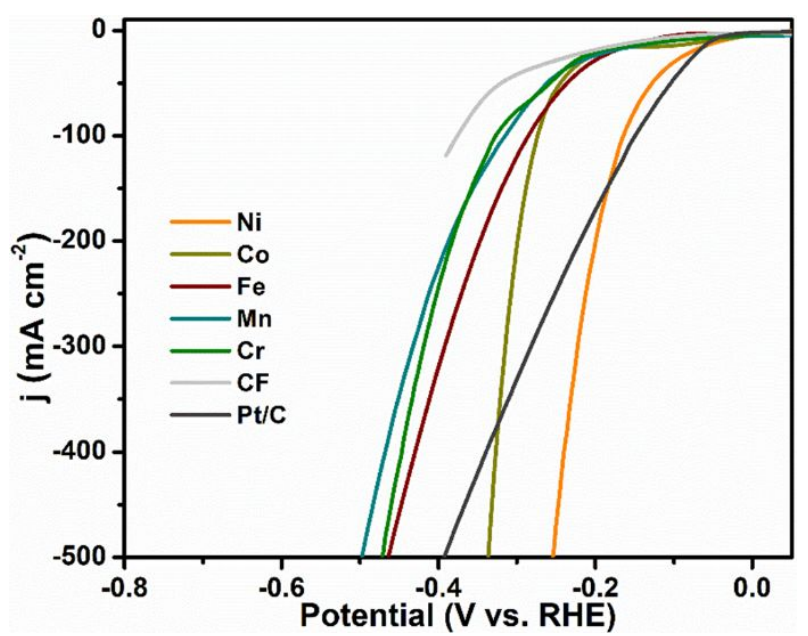

Figure S41. Uncorrected LSVs of catalysts when substituting Ni with other metals, demonstrating proving the universality and reproductivity of our strategy. 

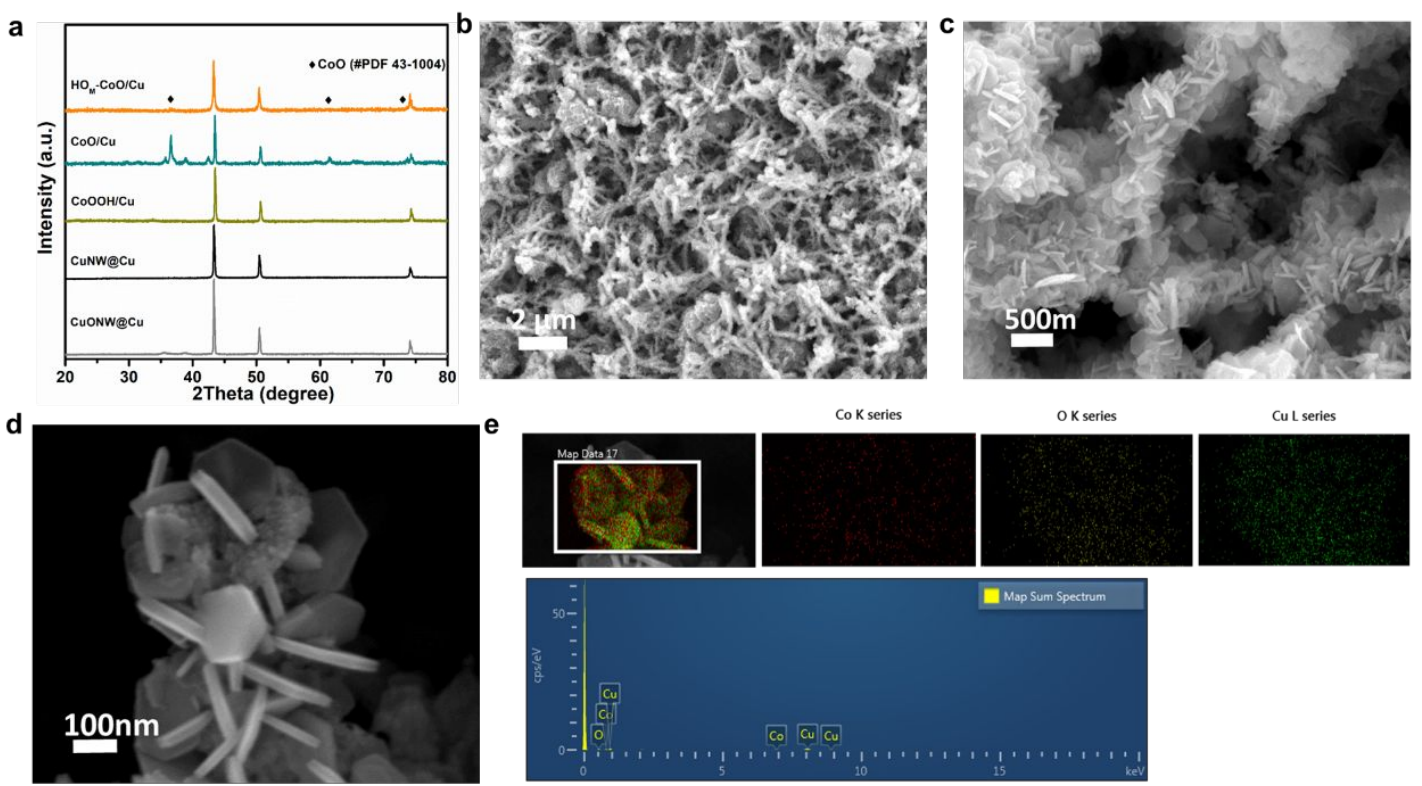

Figure S42. a, b, c, d, e XRD, SEM and elemental mapping images of Co-based catalyst.
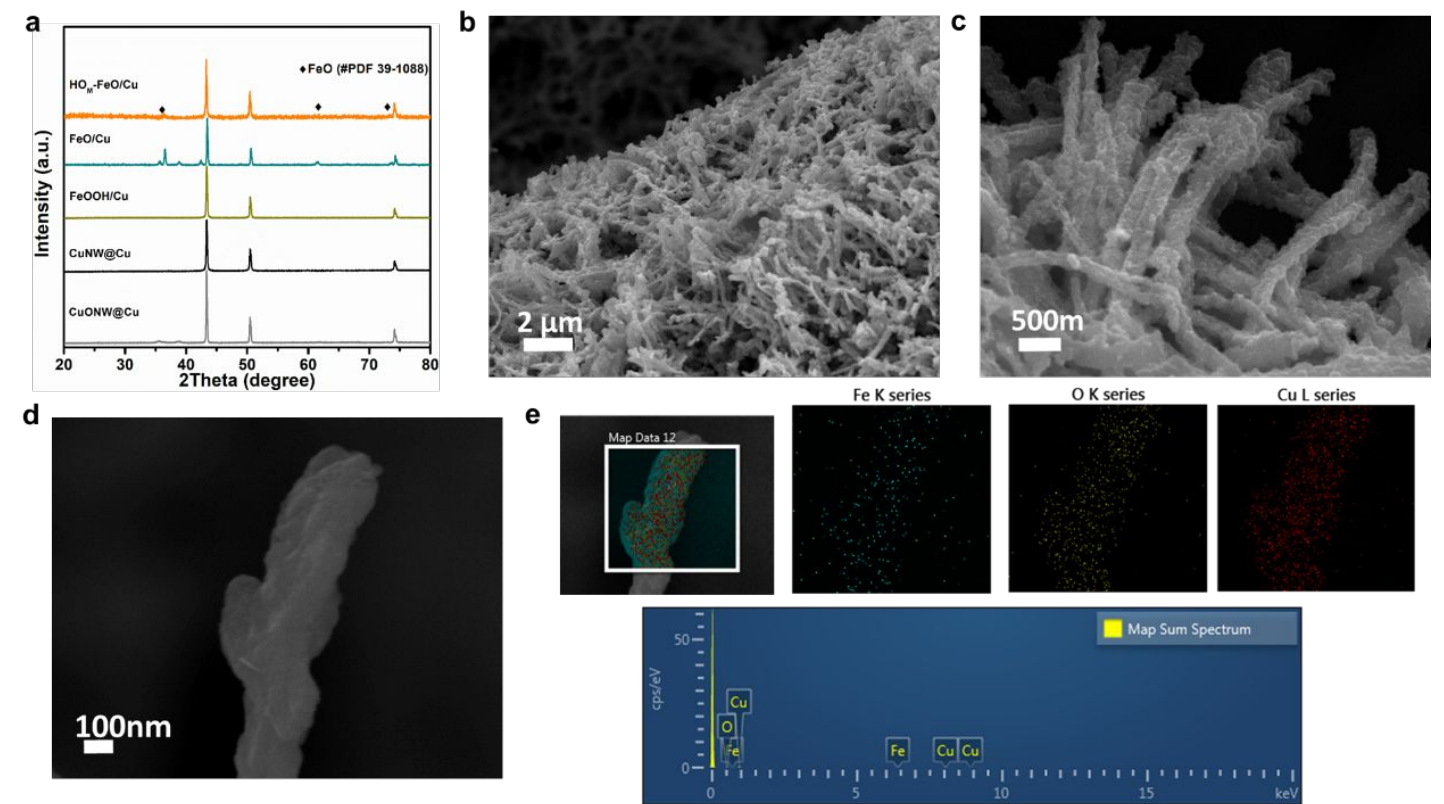

Figure S43. a, b, c, d, e XRD, SEM and elemental mapping images of Fe-based catalyst. 

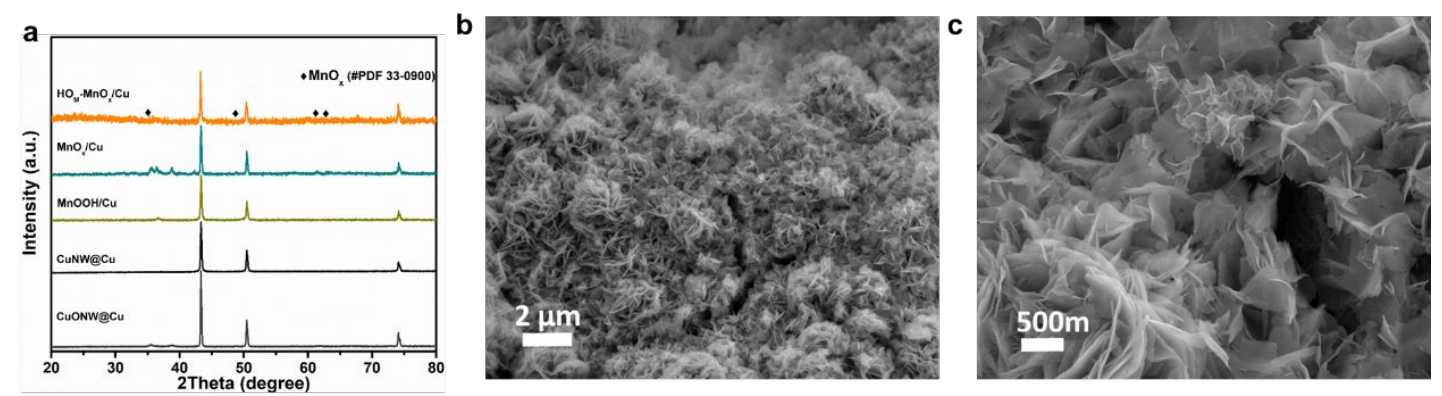

d
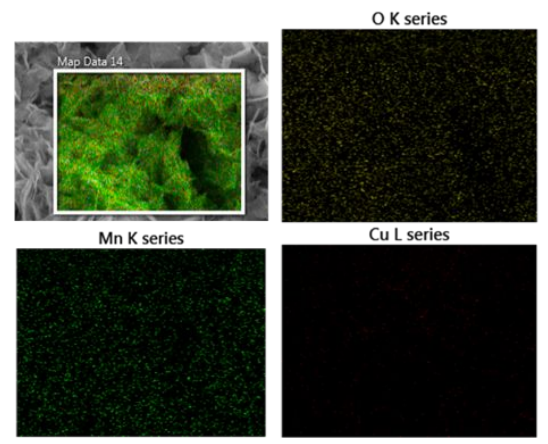

Cu L series

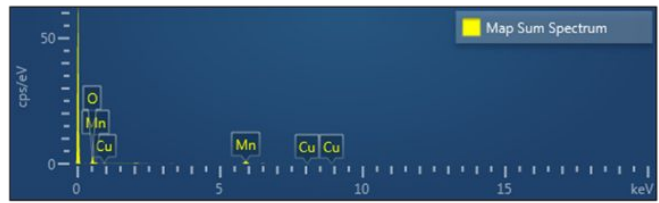

Figure S44. a, b, c, d, e XRD, SEM and elemental mapping images of Mn-based catalyst.
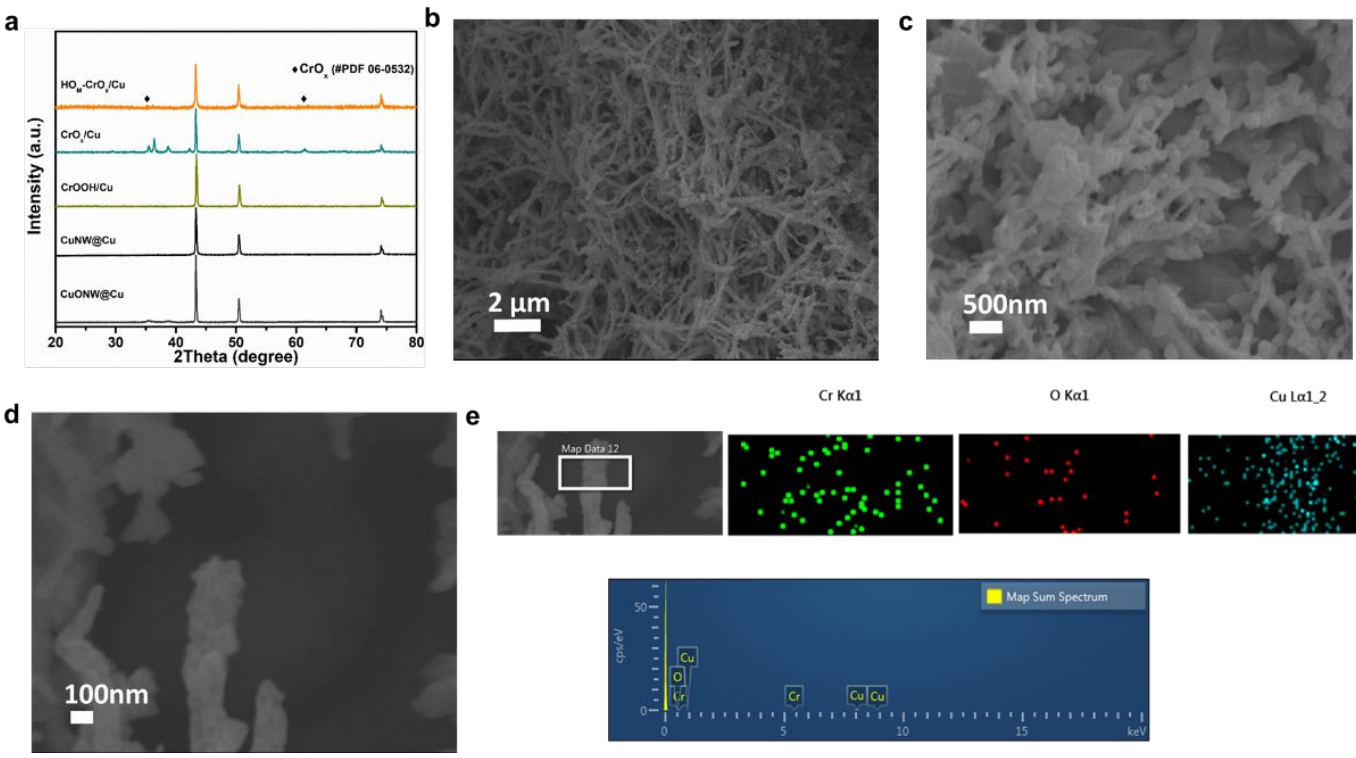

$\mathrm{O} K \alpha 1$

CuLa1_2

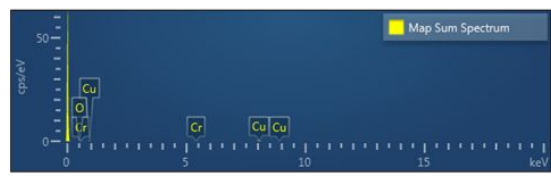

Figure S45. a, b, c, d, e XRD, SEM and elemental mapping images of Cr-based catalyst. 

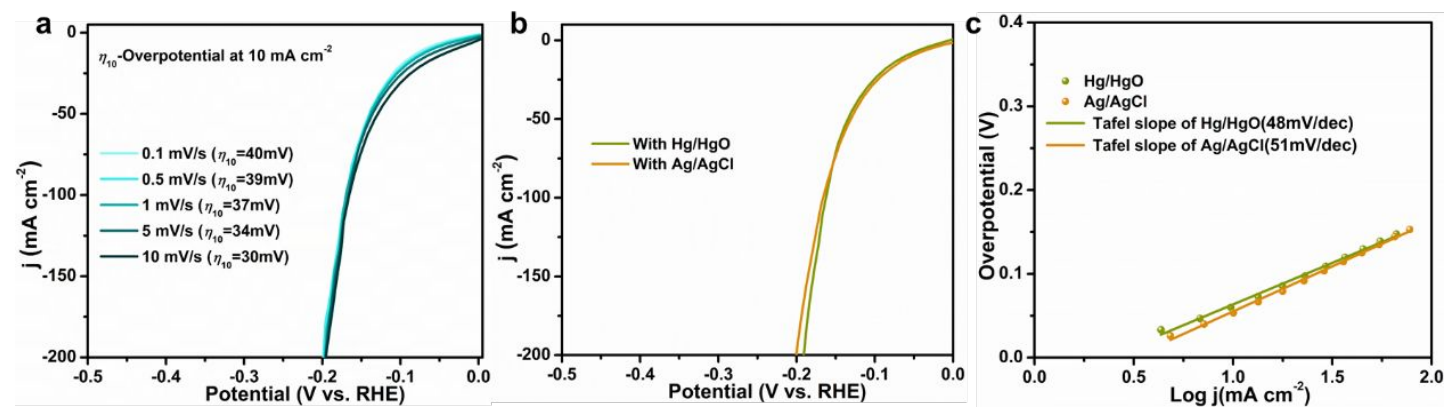

Figure S46. a, $i R$-compensatory LSVs of $\mathrm{HO}_{\mathrm{M}}-\mathrm{NiO} / \mathrm{Cu}$ at differently low scan rates. b,c, $i R$-compensatory LSVs and corresponding Tafel slopes of $\mathrm{HO}_{\mathrm{M}}-\mathrm{NiO} / \mathrm{Cu}$ by using $\mathrm{Hg} / \mathrm{HgO}$ and $\mathrm{Ag} / \mathrm{AgCl}$ as reference electrodes. Negligible performance deviations can be accepted due to the capacitance caused by scan rates. Thus the $5 \mathrm{mV} / \mathrm{s}$ was chosen in this work for energy efficiency. In addition, using $\mathrm{Hg} / \mathrm{HgO}$ as a reference electrode in $1 \mathrm{M} \mathrm{KOH}$ also can investigate the deviation induced by the possible $\mathrm{OH}^{-}$ions leakage in $\mathrm{Ag} / \mathrm{AgCl}$ chamber. No noticeable performance difference including LSV and Tafel slopes was present in the case of $\mathrm{Hg} / \mathrm{HgO}$, so the obtained data based on the utilization of $\mathrm{Ag} / \mathrm{AgCl}$ here is trustworthy. 
Table S1. EXAFS fitting parameters at the Ni k-edge for various samples $\left(\mathrm{S}_{0}{ }^{2}=0.79\right)$. ${ }^{a} N$ : coordination numbers. ${ }^{b} R$ : bond distance. ${ }^{c} \sigma^{2}$ : Debye-Waller factors. ${ }^{d} \Delta E_{0}$ : Inner potential correction factor. $R$ factor: goodness of fit. $S_{0}^{2}$ was set to 0.79 according to the experimental EXAFS fit of a $\mathrm{Ni}$ foil reference by fixing $\mathrm{CN}$ as the known crystallographic value. $\delta$ : valence of Pt.

\begin{tabular}{|c|c|c|c|c|c|c|}
\hline & shell & $\mathrm{CN}$ & $\mathrm{R}(\AA)$ & $\sigma^{2}$ & $\Delta \mathrm{E}_{0}$ & $\mathrm{R}$ factor \\
\hline Ni foil & $\mathrm{Ni}-\mathrm{Ni}$ & 12 & $2.48 \pm 0.02$ & 0.006 & $7.1 \pm 0.5$ & 0.002 \\
\hline \multirow{2}{*}{ NiO Foil } & Ni-O & $7.4 \pm 0.4$ & $2.08 \pm 0.01$ & 0.006 & $11.4 \pm 1.4$ & \multirow{2}{*}{0.004} \\
\hline & $\mathrm{Ni}-\mathrm{Ni}$ & $16.5 \pm 0.6$ & $2.95 \pm 0.01$ & 0.007 & $8.6 \pm 0.9$ & \\
\hline \multirow{2}{*}{$\mathrm{NiOOH} / \mathrm{Cu}$} & $\mathrm{Ni}-\mathrm{O}$ & $5.7 \pm 0.3$ & $2.03 \pm 0.01$ & 0.007 & $7.9 \pm 1.4$ & \multirow{2}{*}{0.017} \\
\hline & $\mathrm{Ni}-\mathrm{Ni}$ & $4.6 \pm 0.5$ & $3.09 \pm 0.02$ & 0.008 & $11.1 \pm 2.7$ & \\
\hline \multirow{2}{*}{$\mathrm{NiO} / \mathrm{Cu}$} & $\mathrm{Ni}-\mathrm{O}$ & $5.6 \pm 0.4$ & $2.08 \pm 0.01$ & 0.007 & $11.1 \pm 1.5$ & \multirow{2}{*}{0.006} \\
\hline & $\mathrm{Ni}-\mathrm{Ni}$ & $12.3 \pm 0.5$ & $2.95 \pm 0.01$ & 0.008 & $8.7 \pm 1.1$ & \\
\hline \multirow{2}{*}{$\mathrm{HO}_{\mathrm{L}}-\mathrm{NiO} / \mathrm{Cu}$} & Ni-O & $5.7 \pm 0.3$ & $2.09 \pm 0.01$ & 0.007 & $11.1 \pm 1.0$ & \multirow{2}{*}{0.003} \\
\hline & $\mathrm{Ni}-\mathrm{Ni}$ & $12.2 \pm 0.4$ & $2.95 \pm 0.00$ & 0.008 & $8.2 \pm 0.7$ & \\
\hline \multirow{2}{*}{$\mathrm{HO}_{\mathrm{M}}-\mathrm{NiO} / \mathrm{Cu}$} & $\mathrm{Ni}-\mathrm{O}$ & $6.0 \pm 0.3$ & $2.09 \pm 0.01$ & 0.007 & $11.8 \pm 1.3$ & \multirow{2}{*}{0.005} \\
\hline & $\mathrm{Ni}-\mathrm{Ni}$ & $13.6 \pm 0.5$ & $2.95 \pm 0.01$ & 0.008 & $8.3 \pm 0.9$ & \\
\hline \multirow{2}{*}{$\mathrm{HO}_{\mathrm{H}}-\mathrm{NiO} / \mathrm{Cu}$} & $\mathrm{Ni}-\mathrm{O}$ & $6.1 \pm 0.3$ & $2.09 \pm 0.01$ & 0.007 & $11.8 \pm 1.4$ & \multirow{2}{*}{0.005} \\
\hline & $\mathrm{Ni}-\mathrm{Ni}$ & $13.6 \pm 0.5$ & $2.95 \pm 0.01$ & 0.008 & $8.2 \pm 0.9$ & \\
\hline
\end{tabular}

More specific information in the bulk phase is needed and can be investigated from EXAFS fitting parameters (Table S1). Obviously, $\mathrm{CN}$ of $\mathrm{Ni}-\mathrm{O}$ bond and $\mathrm{Ni}-\mathrm{Ni}$ increased to $6.0 \pm 0.3$ and $13.6 \pm 0.5$ in $\mathrm{HO}_{\mathrm{M}}-\mathrm{NiO} / \mathrm{Cu}$ from $5.6 \pm 0.4$ and $12.3 \pm 0.5$ of $\mathrm{NiO} / \mathrm{Cu}$, respectively. Compared with $\mathrm{NiO} / \mathrm{Cu}$, bond distances $\left({ }^{b} R\right)$ of $\mathrm{Ni}-\mathrm{O}$ only have an inconspicuous increment of $0.1 \AA \pm 0.01$ in $\mathrm{HO}_{\mathrm{M}}-\mathrm{NiO} / \mathrm{Cu}$ and no difference of Ni-Ni was found. Combined with the results of XPS, these findings reflect the stable nature of $\mathrm{NiO}$ but certain alterations due to the local hydroxylation. 
Table S2. Comparison of the HER performance with $i R$-correction of analogous catalysts in $1 \mathrm{M} \mathrm{KOH}$ or PBS $(\mathrm{PH}=7.4)$ media. $\left(\eta_{10}(\mathrm{mV})\right.$-the overpotential at the current density of $10 \mathrm{~mA} \mathrm{~cm}^{-2}, \mathrm{j} @ 250$ - the current at the overpotential of $205 \mathrm{mV}$ )

\begin{tabular}{|c|c|c|c|c|c|c|}
\hline Catalysts & substrate & $\begin{array}{l}\text { Loading } \\
\left(\mathrm{mg} \mathrm{cm}^{-2}\right)\end{array}$ & $\begin{array}{c}\eta_{10} \\
(\mathrm{mV})\end{array}$ & $\begin{array}{c}\text { Tafel } \\
\text { Slope(mV/dec) }\end{array}$ & j@250 & Reference \\
\hline $\mathrm{HO}_{\mathrm{M}}-\mathrm{NiO} / \mathrm{Cu}$ & Copper & 1.8 & 33 & 51 & 470 & This work \\
\hline $\mathrm{HO}_{\mathrm{M}}-\mathrm{NiO} / \mathrm{Cu}$ & Copper & 1.8 & 85(PBS) & 87 & 75 & This work \\
\hline $\mathrm{Mo}-\mathrm{NiO} / \mathrm{Ni}$ & GCE & 0.8 & 50 & 86 & 200 & $\begin{array}{c}\text { ACS Energy Lett. } \\
\text { 2019, 4, } 3002\end{array}$ \\
\hline $\mathrm{PA}-\mathrm{NiO}$ & $\begin{array}{l}\text { Nickel } \\
\text { foam }\end{array}$ & unknown & 138 & 81 & 150 & $\begin{array}{c}\text { ACS Energy Lett. } \\
2018,3,892\end{array}$ \\
\hline $\mathrm{Ni@NiO}$ & $\begin{array}{l}\text { Nickel } \\
\text { foam }\end{array}$ & unknown & 146 & 72 & 200 & $\begin{array}{c}\text { Small 2018, 14, } \\
1800294\end{array}$ \\
\hline $\mathrm{NiO}$ & CFP & 0.2 & 150 & 100 & 100 & $\begin{array}{c}\text { Nano Energy 2018, } \\
43,103\end{array}$ \\
\hline $\mathrm{Ni}-\mathrm{Mo}-\mathrm{O}$ & $\begin{array}{l}\text { Nickel } \\
\text { foam }\end{array}$ & 4.5 & 20 & 34 & 600 & $\begin{array}{c}\text { Energy Environ. } \\
\text { Sci., 2018, 11, } 1890\end{array}$ \\
\hline $\mathrm{Ni}_{3} \mathrm{~N} / \mathrm{Ni}$ & $\begin{array}{l}\text { Nickel } \\
\text { foam }\end{array}$ & 2.5 & 30 & 30 & 400 & $\begin{array}{l}\text { Nat. Commun. 2018, } \\
9,4531\end{array}$ \\
\hline $\mathrm{Ni}-\mathrm{N}$ & $\begin{array}{l}\text { Nickel } \\
\text { foam }\end{array}$ & high & 30 & 42 & 300 & $\begin{array}{l}\text { Angew. Chem. Int. } \\
\text { Ed. } 2019,58,461\end{array}$ \\
\hline $\mathrm{Ni} / \mathrm{NiO}$ & $\begin{array}{l}\text { Nickel } \\
\text { foam }\end{array}$ & 0.8 & 90 & 41 & 100 & $\begin{array}{c}\text { National Science } \\
\text { Review, } 2019 .\end{array}$ \\
\hline PO-Ni/Ni-N-CNFs & GCE & 2 & 262 & 97 & 40 & $\begin{array}{c}\text { Nano Energy 2018, } \\
51,286\end{array}$ \\
\hline $\mathrm{NiO} / \mathrm{Ni}-\mathrm{CNT}$ & GCE & 0.4 & 90 & 82 & 300 & $\begin{array}{c}\text { Nature } \\
\text { communications, } \\
2014,5,4695\end{array}$ \\
\hline $\mathrm{Ni}_{11}\left(\mathrm{HPO}_{3}\right)_{8}(\mathrm{OH})_{6} / \mathrm{NF}$ & $\begin{array}{l}\text { Nickel } \\
\text { foam }\end{array}$ & 3 & 42 & 102 & 100 & $\begin{array}{c}\text { Energy Environ. } \\
\text { Sci., 2018, 11, } 1287\end{array}$ \\
\hline $\mathrm{N}-\mathrm{NiCo}_{2} \mathrm{~S}_{4}$ & $\begin{array}{l}\text { Nickel } \\
\text { foam }\end{array}$ & 2.3 & 41 & 37 & 300 & $\begin{array}{c}\text { Nature } \\
\text { communications, } \\
2018,9,425\end{array}$ \\
\hline $\mathrm{Ni}, \mathrm{Zn}-\mathrm{CoO}$ & $\begin{array}{c}\text { Carbon } \\
\text { fiber paper }\end{array}$ & 2 & 53 & 47 & 300 & $\begin{array}{c}\text { Advanced Materials, } \\
2019,31,807771\end{array}$ \\
\hline
\end{tabular}


Table S3. Comparison of the overall-water-splitting activities among various earthabundant electrocatalysts tested in various conditions. $\eta_{50}$ corresponds to the cell voltages of the overall-water-splitting cell operated at $50 \mathrm{~mA} \mathrm{~cm}^{-2}$, respectively. $j_{1.6} \mathrm{~V}$ represents the current density at the cell voltage of $1.6 \mathrm{~V}$. (The parameters in this work are original data without $i R$-correction)

\begin{tabular}{|c|c|c|c|c|}
\hline Catalyst & Electrolyte & $\begin{array}{l}\eta_{50}(\mathrm{mV})- \\
\text { overall water } \\
\text { splitting }\end{array}$ & $\mathbf{j}_{1.6}(\mathrm{~mA})$ & Reference \\
\hline $\mathrm{HO}_{\mathrm{M}}-\mathrm{NiO} / \mathrm{Cu} / / \mathrm{NiOOH} / \mathrm{Cu}$ & $25^{\circ} \mathrm{C}, 1 \mathrm{M} \mathrm{KOH}$ & 1.5 & 61 & This work \\
\hline $\mathrm{HO}_{\mathrm{M}}-\mathrm{NiO} / \mathrm{Cu} / / \mathrm{NiOOH} / \mathrm{Cu}$ & $1 \mathrm{M} \mathrm{KOH}+0.6 \mathrm{M} \mathrm{NaCl}$ & 1.51 & 58 & This work \\
\hline $\mathrm{HO}_{\mathrm{M}}-\mathrm{NiO} / \mathrm{Cu} / / \mathrm{NiOOH} / \mathrm{Cu}$ & $40{ }^{\circ} \mathrm{C}, 1 \mathrm{M} \mathrm{KOH}$ & 1.49 & 72 & This work \\
\hline $\mathrm{HO}_{\mathrm{M}}-\mathrm{NiO} / \mathrm{Cu} / / \mathrm{NiOOH} / \mathrm{Cu}$ & $60{ }^{\circ} \mathrm{C}, 1 \mathrm{M} \mathrm{KOH}$ & 1.46 & 102 & This work \\
\hline $\mathrm{HO}_{\mathrm{M}}-\mathrm{NiO} / \mathrm{Cu} / / \mathrm{NiOOH} / \mathrm{Cu}$ & $90^{\circ} \mathrm{C}, 1 \mathrm{M} \mathrm{KOH}$ & 1.40 & 179 & This work \\
\hline $\mathrm{Pt} / \mathrm{C} / \mathrm{Cu} / / \mathrm{RuO}_{2} / \mathrm{Cu}$ & $25^{\circ} \mathrm{C}, 1 \mathrm{M} \mathrm{KOH}$ & 1.7 & 20 & This work \\
\hline $\mathrm{PA}-\mathrm{NiO} / / \mathrm{PA}-\mathrm{NiO}$ & $1 \mathrm{M} \mathrm{KOH}$ & 1.7 & 15 & $\begin{array}{c}\text { ACS Energy Lett. 2018, 3, } \\
892\end{array}$ \\
\hline Ni@NiO//Ni@NiO & $1 \mathrm{M} \mathrm{KOH}$ & 1.7 & 5 & Small 2018, 14, 1800294 \\
\hline $\begin{array}{l}\text { PO-Ni/Ni-N-CNFs// } \\
\text { PO-Ni/Ni-N-CNFs }\end{array}$ & $1 \mathrm{M} \mathrm{KOH}$ & 1.8 & 5 & $\begin{array}{l}\text { Nano Energy 2018, 51, } \\
286\end{array}$ \\
\hline $\begin{array}{l}\mathrm{NF} @ \mathrm{Ni} / \mathrm{C}-600 / / \\
\mathrm{NF} @ \mathrm{Ni} / \mathrm{C}-600\end{array}$ & $1 \mathrm{M} \mathrm{KOH}$ & 1.65 & 36 & $\begin{array}{l}\text { Energy \& Environmental } \\
\text { Science, } 2018,11,2363\end{array}$ \\
\hline $\mathrm{FeP} / \mathrm{Ni}_{2} \mathrm{P} / / \mathrm{FeP} / \mathrm{Ni}_{2} \mathrm{P}$ & $1 \mathrm{M} \mathrm{KOH}$ & 1.55 & 40 & $\begin{array}{l}\text { Nature communications, } \\
\qquad 2018,9,2551\end{array}$ \\
\hline $\begin{array}{c}\mathrm{Ni}_{11}\left(\mathrm{HPO}_{3}\right)_{8}(\mathrm{OH})_{6} / \mathrm{NF} / / \\
\mathrm{Ni}_{11}\left(\mathrm{HPO}_{3}\right)_{8}(\mathrm{OH})_{6} / \mathrm{NF}\end{array}$ & $1 \mathrm{M} \mathrm{KOH}$ & 2 & 9 & $\begin{array}{l}\text { Energy Environ. Sci., } \\
\qquad 2018,11,1287\end{array}$ \\
\hline $\mathrm{NiO} / \mathrm{Ni}-\mathrm{CNT} / / \mathrm{NiFe} \mathrm{LDH}$ & $23^{\circ} \mathrm{C}, 1 \mathrm{M} \mathrm{KOH}$ & 1.55 & 60 & $\begin{array}{l}\text { Nature communications, } \\
\qquad 2014,5,4695\end{array}$ \\
\hline $\mathrm{Fe}-\mathrm{Ni}_{2} \mathrm{P} / / \mathrm{Fe}-\mathrm{Ni}_{2} \mathrm{P}$ & $1 \mathrm{M} \mathrm{KOH}$ & 1.65 & 20 & $\begin{array}{c}\text { Advanced Functional } \\
\text { Materials, 2017, 27, } \\
1702513\end{array}$ \\
\hline $\mathrm{NiFeSP} / \mathrm{NF} / / \mathrm{NiFeSP} / \mathrm{NF}$ & $1 \mathrm{M} \mathrm{KOH}$ & 1.82 & 10 & $\begin{array}{c}\text { ACS nano, 2017, 11, } \\
10303\end{array}$ \\
\hline $\mathrm{Fe}-\mathrm{Ni}_{2} \mathrm{P} / / \mathrm{Fe}-\mathrm{Ni}_{2} \mathrm{P}$ & $1 \mathrm{M} \mathrm{KOH}$ & 1.65 & 25 & $\begin{array}{l}\text { Adv. Funct. Mater., 2017, } \\
\text { 27, } 1702513\end{array}$ \\
\hline $\begin{array}{l}\mathrm{Se}-(\mathrm{NiCo}) \mathrm{Sx} /(\mathrm{OH}) \mathrm{x} / / \\
\mathrm{Se}-(\mathrm{NiCo}) \mathrm{Sx} /(\mathrm{OH}) \mathrm{x}\end{array}$ & $1 \mathrm{M} \mathrm{KOH}$ & 1.8 & 10 & $\begin{array}{c}\text { Advanced Materials, 2018, } \\
\text { 30, } 1705538\end{array}$ \\
\hline $\begin{array}{l}\text { Fe-Ni@NC-CNTs// } \\
\text { Fe-Ni@NC-CNTs }\end{array}$ & $1 \mathrm{M} \mathrm{KOH}$ & 1.82 & 5 & $\begin{array}{l}\text { Angewandte Chemie } \\
\text { International Edition, } \\
\quad 2018,57,8921\end{array}$ \\
\hline $\begin{array}{l}\mathrm{Fe} 11 \%-\mathrm{NiO} / \mathrm{NF} / / \\
\mathrm{Fe} 11 \%-\mathrm{NiO} / \mathrm{NF}\end{array}$ & $1 \mathrm{M} \mathrm{KOH}$ & 1.7 & 20 & $\begin{array}{c}\text { Journal of catalysis, } 2018 \text {, } \\
\qquad 358,243\end{array}$ \\
\hline
\end{tabular}


Table S4. Fitting parameters for EIS data of the Cu catalyst for HER.

\begin{tabular}{|c|c|c|c|c|c|c|}
\hline$\eta(\mathrm{mV})$ & $\mathrm{R}_{\mathrm{s}}(\Omega)$ & Q & Q-n & $\mathrm{R}_{1}(\Omega)$ & $\mathrm{C}_{\varphi}(\mathrm{F})$ & $\mathrm{R}_{2}(\Omega)$ \\
\hline 0 & 3.246 & 0.00263 & 0.7894 & 16.25 & 0.00952 & 870.74 \\
\hline 20 & 3.242 & 0.002533 & 0.7944 & 10.76 & 0.01010 & 771.5 \\
\hline 40 & 3.245 & 0.002570 & 0.7945 & 9.74 & 0.01204 & 745.34 \\
\hline 60 & 3.235 & 0.002720 & 0.7939 & 9.504 & 0.01330 & 698 \\
\hline 80 & 3.236 & 0.003006 & 0.7914 & 8.84 & 0.0134 & 607.2 \\
\hline 100 & 3.186 & 0.002847 & 0.7301 & 8.19 & 0.0143 & 573.15 \\
\hline 120 & 3.186 & 0.002924 & 0.7199 & 7.09 & 0.0155 & 509 \\
\hline 140 & 3.198 & 0.003277 & 0.07143 & 6.674 & 0.0176 & 195 \\
\hline 160 & 3.216 & 0.003895 & 0.7039 & 6.176 & 0.02076 & 113.9 \\
\hline 180 & 3.209 & 0.003993 & 0.7421 & 3.429 & 0.02422 & 75.65 \\
\hline 200 & 3.226 & 0.003727 & 0.76230 & 2.185 & 0.0241 & 49.83 \\
\hline 220 & 3.25 & 0.00330 & 0.7505 & 2.088 & 0.027 & 40.85 \\
\hline 240 & 3.242 & 0.002777 & 0.7458 & 1.811 & 0.02510 & 32.12 \\
\hline 260 & 3.248 & 0.002253 & 0.7679 & 1.484 & 0.02047 & 29.93 \\
\hline 280 & 3.259 & 0.001908 & 0.7956 & 1.255 & 0.01556 & 26.45 \\
\hline 300 & 3.200 & 0.001307 & 0.7328 & 0.9675 & 0.01478 & 22.82 \\
\hline 320 & 3.204 & 0.001057 & 0.7621 & 0.956 & 0.01083 & 17.83 \\
\hline 340 & 3.187 & 0.001082 & 0.7742 & 0.9153 & 0.00966 & 13.91 \\
\hline 360 & 3.218 & 0.007318 & 0.7625 & 0.8778 & 0.00940 & 9.501 \\
\hline 380 & 3.201 & 0.003208 & 0.7824 & 0.8244 & 0.01007 & 6.66 \\
\hline 400 & 3.214 & 0.002845 & 0.7763 & 0.7412 & 0.01146 & 4.58 \\
\hline
\end{tabular}


Table S5. Fitting parameters of the EIS data of $\mathrm{NiOOH} / \mathrm{Cu}$ catalyst for HER.

\begin{tabular}{ccccccc}
\hline$\eta(\mathrm{mV})$ & $\mathrm{R}_{\mathrm{s}}(\Omega)$ & $\mathrm{Q}$ & $\mathrm{Q}-\mathrm{n}$ & $\mathrm{R}_{1}(\Omega)$ & $\mathrm{C}_{\varphi}(\mathrm{F})$ & $\mathrm{R}_{2}(\Omega)$ \\
\hline 0 & 2.380 & 0.01813 & 0.8436 & 23.52 & 0.02083 & 136 \\
\hline 20 & 2.379 & 0.01577 & 0.8267 & 19.7 & 0.02998 & 117.44 \\
\hline 40 & 2.372 & 0.01584 & 0.852 & 17.35 & 0.03061 & 113.1 \\
\hline 60 & 2.378 & 0.01562 & 0.8284 & 19.41 & 0.03290 & 89.2 \\
\hline 80 & 2.374 & 0.01597 & 0.853 & 16.5 & 0.03006 & 62.54 \\
\hline 100 & 2.382 & 0.01827 & 0.8355 & 13.55 & 0.02832 & 56.82 \\
\hline 120 & 2.358 & 0.01504 & 0.8428 & 8.142 & 0.02506 & 27.54 \\
\hline 140 & 2.374 & 0.01607 & 0.8403 & 5.894 & 0.01833 & 11.79 \\
\hline 160 & 2.340 & 0.01279 & 0.8187 & 1.433 & 0.0236 & 14.74 \\
\hline 180 & 2.340 & 0.01167 & 0.8196 & 1.093 & 0.0248 & 10.01 \\
\hline 200 & 2.328 & 0.009816 & 0.8202 & 0.8822 & 0.0246 & 7.056 \\
\hline 220 & 2.322 & 0.008503 & 0.8239 & 0.7634 & 0.02567 & 4.986 \\
\hline 240 & 2.317 & 0.007874 & 0.8321 & 0.6892 & 0.02678 & 3.544 \\
\hline 260 & 2.316 & 0.007030 & 0.8292 & 0.6612 & 0.0269 & 2.783 \\
\hline 280 & 2.308 & 0.006088 & 0.8411 & 0.5549 & 0.0270 & 2.178 \\
\hline 300 & 2.359 & 0.005997 & 0.8214 & 0.5120 & 0.02741 & 1.2114 \\
\hline
\end{tabular}


Table S6. Fitting parameters of the EIS data of $\mathrm{NiO} / \mathrm{Cu}$ catalyst for HER.

\begin{tabular}{|c|c|c|c|c|c|c|}
\hline$\eta(\mathrm{mV})$ & $\mathrm{R}_{\mathrm{s}}(\Omega)$ & $\mathrm{Q}(\mathrm{F})$ & Q-n & $\mathrm{R}_{1}(\Omega)$ & $\mathrm{C}_{\varphi}(\mathrm{F})$ & $\mathrm{R}_{2}(\Omega)$ \\
\hline 0 & 2.548 & 0.00336 & 0.8099 & 14.35 & 0.1695 & 90.09 \\
\hline 20 & 2.545 & 0.00384 & 0.8000 & 1.414 & 0.1691 & 75.54 \\
\hline 40 & 2.564 & 0.04120 & 0.7965 & 1.417 & 0.1868 & 55.75 \\
\hline 60 & 2.569 & 0.04675 & 0.7825 & 1.339 & 0.2139 & 42.19 \\
\hline 80 & 2.567 & 0.05217 & 0.8132 & 1.305 & 0.2183 & 30.17 \\
\hline 100 & 2.568 & 0.05428 & 0.7619 & 1.447 & 0.2246 & 21.06 \\
\hline 120 & 2.609 & 0.06352 & 0.7744 & 1.467 & 0.2374 & 17.36 \\
\hline 140 & 2.600 & 0.06206 & 0.8000 & 1.375 & 0.2486 & 12.84 \\
\hline 160 & 4.137 & 0.06341 & 0.7164 & 1.452 & 0.2675 & 8.643 \\
\hline 180 & 4.083 & 0.06344 & 0.73945 & 1.438 & 0.2196 & 5.945 \\
\hline 200 & 2.817 & 0.05445 & 0.7491 & 1.188 & 0.2147 & 4.435 \\
\hline 220 & 2.945 & 0.05006 & 0.7482 & 1.062 & 0.2209 & 4.845 \\
\hline 240 & 3.782 & 0.04494 & 0.7409 & 0.944 & 0.2221 & 3.467 \\
\hline 260 & 3.811 & 0.0534 & 0.7564 & 0.8743 & 0.2078 & 2.834 \\
\hline 280 & 3.343 & 0.03884 & 0.7209 & 0.7188 & 0.2096 & 2.1 \\
\hline 300 & 3.427 & 0.03490 & 0.7147 & 0.6104 & 0.1822 & 1.893 \\
\hline
\end{tabular}


Table S7. Fitting parameters of the EIS data of $\mathrm{HO}_{\mathrm{L}}-\mathrm{NiO} / \mathrm{Cu}$ catalyst for HER.

\begin{tabular}{|c|c|c|c|c|c|c|}
\hline$\eta(\mathrm{mV})$ & $\mathrm{R}_{\mathrm{s}}(\Omega)$ & $\mathrm{Q}(\mathrm{F})$ & Q-n & $\mathrm{R}_{1}(\Omega)$ & $\mathrm{C}_{\varphi}(\mathrm{F})$ & $\mathrm{R}_{2}(\Omega)$ \\
\hline 0 & 4.839 & 0.03523 & 0.7827 & 19.911 & 0.09667 & 42.5 \\
\hline 20 & 4.692 & 0.03164 & 0.8227 & 4.519 & 0.1290 & 35.69 \\
\hline 40 & 4.898 & 0.04614 & 0.7872 & 4.025 & 0.1361 & 30.12 \\
\hline 60 & 4.913 & 0.05104 & 0.8065 & 3.487 & 0.1412 & 26.75 \\
\hline 80 & 5.030 & 0.05712 & 0.7962 & 2.035 & 0.1398 & 20.79 \\
\hline 100 & 5.084 & 0.04797 & 0.7483 & 1.928 & 0.1437 & 17.28 \\
\hline 120 & 5.197 & 0.0525 & 0.7398 & 1.904 & 0.1666 & 13.52 \\
\hline 140 & 5.268 & 0.05807 & 0.7564 & 1.831 & 0.1943 & 10.97 \\
\hline 160 & 5.403 & 0.0602 & 0.7456 & 1.959 & 0.2236 & 8.275 \\
\hline 180 & 5.272 & 0.05959 & 0.7523 & 1.771 & 0.2218 & 6.563 \\
\hline 200 & 5.213 & 0.05219 & 0.7748 & 1.577 & 0.2164 & 5.311 \\
\hline 220 & 5.046 & 0.05185 & 0.7321 & 1.425 & 0.2165 & 4.053 \\
\hline 240 & 5.377 & 0.06263 & 0.7674 & 1.156 & 0.2085 & 3.744 \\
\hline 260 & 5.325 & 0.05867 & 0.7754 & 1.127 & 0.1964 & 3.26 \\
\hline 280 & 5.356 & 0.05471 & 0.7861 & 1.03 & 0.2016 & 2.597 \\
\hline 300 & 5.353 & 0.03568 & 0.7463 & 0.9538 & 0.1983 & 1.97 \\
\hline
\end{tabular}


Table S8. Fitting parameters of the EIS data of $\mathrm{HO}_{\mathrm{M}}-\mathrm{NiO} / \mathrm{Cu}$ catalyst for HER.

\begin{tabular}{|c|c|c|c|c|c|c|}
\hline$\eta(\mathrm{mV})$ & $\mathrm{R}_{\mathrm{s}}(\Omega)$ & $\mathrm{Q}(\mathrm{F})$ & Q-n & $\mathrm{R}_{1}(\Omega)$ & $\mathrm{C}_{\varphi}(\mathrm{F})$ & $\mathrm{R}_{2}(\Omega)$ \\
\hline 0 & 2.715 & 0.05528 & 0.7622 & 14.92 & 0.09642 & 33.76 \\
\hline 20 & 2.674 & 0.04959 & 0.6976 & 1.22 & 0.1228 & 13.55 \\
\hline 40 & 2.675 & 0.04803 & 0.7139 & 1.383 & 0.1435 & 11.6 \\
\hline 60 & 2.690 & 0.05167 & 0.7253 & 1.541 & 0.1485 & 9.851 \\
\hline 80 & 2.684 & 0.05415 & 0.7240 & 1.45 & 0.1659 & 8.303 \\
\hline 100 & 2.683 & 0.05782 & 0.7158 & 1.446 & 0.1802 & 6.869 \\
\hline 120 & 2.675 & 0.06198 & 0.7006 & 1.438 & 0.1945 & 5.503 \\
\hline 140 & 2.687 & 0.06438 & 0.6868 & 1.359 & 0.2114 & 4.425 \\
\hline 160 & 2.693 & 0.0673 & 0.6898 & 1.276 & 0.2401 & 3.284 \\
\hline 180 & 2.529 & 0.06585 & 0.6971 & 1.155 & 0.2623 & 2.471 \\
\hline 200 & 2.529 & 0.06393 & 0.6866 & 1.108 & 0.2635 & 1.923 \\
\hline 220 & 2.543 & 0.05715 & 0.6991 & 0.9583 & 0.3104 & 1.472 \\
\hline 240 & 2.570 & 0.05887 & 0.6863 & 0.9187 & 0.3059 & 1.154 \\
\hline 260 & 2.530 & 0.04973 & 0.6986 & 0.7992 & 0.2987 & 0.9239 \\
\hline 280 & 2.535 & 0.05492 & 0.6704 & 0.7386 & 0.2805 & 0.7817 \\
\hline 300 & 2.475 & 0.04311 & 0.6956 & 0.6674 & 0.3368 & 0.6258 \\
\hline
\end{tabular}


Table S9. Fitting parameters of the EIS data of $\mathrm{HO}_{\mathrm{H}}-\mathrm{NiO} / \mathrm{Cu}$ catalyst for HER.

\begin{tabular}{|c|c|c|c|c|c|c|}
\hline$\eta(\mathrm{mV})$ & $\mathrm{R}_{\mathrm{s}}(\Omega)$ & $\mathrm{Q}(\mathrm{F})$ & Q-n & $\mathrm{R}_{1}(\Omega)$ & $\mathrm{C}_{\varphi}(\mathrm{F})$ & $\mathrm{R}_{2}(\Omega)$ \\
\hline 0 & 2.691 & 0.03112 & 0.7982 & 15.55 & 0.0957 & 61.72 \\
\hline 20 & 2.686 & 0.02943 & 0.808 & 1.634 & 0.09821 & 51.44 \\
\hline 40 & 2.686 & 0.03171 & 0.7938 & 1.393 & 0.1047 & 42 \\
\hline 60 & 2.690 & 0.03486 & 0.7953 & 1.452 & 0.1263 & 41.36 \\
\hline 80 & 2.693 & 0.04007 & 0.792 & 1.699 & 0.1493 & 35.63 \\
\hline 100 & 2.670 & 0.05254 & 0.8 & 1.307 & 0.1326 & 29.3 \\
\hline 120 & 2.678 & 0.05958 & 0.757 & 1.707 & 0.1474 & 21.13 \\
\hline 140 & 2.681 & 0.06579 & 0.0718 & 1.944 & 0.1868 & 15.01 \\
\hline 160 & 2.718 & 0.06403 & 0.7481 & 1.834 & 0.1876 & 11.34 \\
\hline 180 & 2.678 & 0.06094 & 0.7154 & 1.741 & 0.1828 & 8.06 \\
\hline 200 & 2.677 & 0.05381 & 0.7149 & 1.498 & 0.1719 & 6.046 \\
\hline 220 & 2.713 & 0.06287 & 0.7451 & 1.207 & 0.1674 & 5.134 \\
\hline 240 & 2.708 & 0.05195 & 0.7548 & 1.053 & 0.1712 & 4.03 \\
\hline 260 & 2.680 & 0.03576 & 0.7142 & 0.9196 & 0.1622 & 2.758 \\
\hline 280 & 2.675 & 0.02954 & 0.7246 & 0.8278 & 0.1594 & 2.117 \\
\hline 300 & 2.677 & 0.02342 & 0.7317 & 0.7074 & 0.1601 & 1.353 \\
\hline
\end{tabular}


Table S10. Fitting parameters of the EIS data of phy- $\mathrm{HO}_{\mathrm{M}}-\mathrm{NiO} / \mathrm{Cu}$ (physical loading $\mathrm{HO}-\mathrm{NiO}$ onto $\mathrm{Cu}$ ) catalyst for HER.

\begin{tabular}{|c|c|c|c|c|c|c|c|}
\hline$\eta(\mathrm{mV})$ & $\mathrm{R}_{\mathrm{s}}(\Omega)$ & $\mathrm{Q}_{1}(\mathrm{~F})$ & $\mathrm{Q}_{1}-\mathrm{n}$ & $\mathrm{R}_{1}(\Omega)$ & $\mathrm{Q}_{2}(\mathrm{~F})$ & $\mathrm{Q}_{2}-\mathrm{n}$ & $\mathrm{R}_{2}(\Omega)$ \\
\hline 0 & 2.752 & 0.0041 & 1.000 & 490.1 & 0.0414 & 1.000 & 431.2 \\
\hline 20 & 2.783 & 0.0217 & 0.936 & 456.7 & 0.0385 & 0.800 & 369.7 \\
\hline 40 & 2.814 & 0.0692 & 0.800 & 443.8 & 0.0205 & 0.9822 & 354.2 \\
\hline 60 & 2.852 & 0.0248 & 0.752 & 435.6 & 0.0240 & 0.831 & 351.3 \\
\hline 80 & 2.789 & 0.0206 & 0.886 & 420.0 & 0.0199 & 0.891 & 300.2 \\
\hline 100 & 2.787 & 0.0223 & 0.897 & 387.1 & 0.0192 & 0.678 & 272.4 \\
\hline 120 & 2.771 & 0.0239 & 0.801 & 310.8 & 0.0219 & 0.803 & 264.5 \\
\hline 140 & 2.771 & 0.0204 & 0.6751 & 245.2 & 0.0248 & 0.875 & 205.7 \\
\hline 160 & 2.766 & 0.0240 & 0.8812 & 194.8 & 0.033 & 0.657 & 182.5 \\
\hline 180 & 2.781 & 0.0231 & 0.645 & 150.4 & 0.027 & 0.817 & 142.1 \\
\hline 200 & 2.650 & 0.0244 & 0.801 & 136.8 & 0.024 & 0.801 & 85.2 \\
\hline 220 & 2.745 & 0.0185 & 0.634 & 95.2 & 0.024 & 0.878 & 57.0 \\
\hline 240 & 2.803 & 0.0184 & 0.639 & 61.7 & 0.022 & 0.844 & 41.8 \\
\hline 260 & 2.821 & 0.0154 & 0.671 & 40.2 & 0.021 & 0.845 & 28.7 \\
\hline 280 & 2.824 & 0.0193 & 0.844 & 20.9 & 0.0296 & 0.634 & 17.0 \\
\hline 300 & 2.839 & 0.0195 & 0.8 & 18.2 & 0.01765 & 0.801 & 15.7 \\
\hline 320 & 2.785 & 0.0206 & 0.6571 & 16.2 & 0.01735 & 0.851 & 11.4 \\
\hline 340 & 2.794 & 0.0178 & 0.842 & 11.2 & 0.0182 & 0.67 & 7.3 \\
\hline 360 & 2.805 & 0.0137 & 0.71 & 6.21 & 0.0164 & 0.831 & 5.9 \\
\hline
\end{tabular}

It can be found that the catalyst obtained by the physical method performs the different equivalent circuit diagrams compared to $\mathrm{HO}_{\mathrm{M}}-\mathrm{NiO} / \mathrm{Cu}$. Herein, $\mathrm{R}_{\mathrm{s}}$ reflects the uncompensated solution resistance. $\mathrm{Q}$ is named as semi-infinite diffusion, general diffusion, and imperfect (leaking) capacitor, and is Cdl (double-layer capacitor) when $\mathrm{Q}-\mathrm{n}=1 . \mathrm{Q}_{1}$ and $\mathrm{Q}_{2}$ represent two kinds of double-layer capacitance contained by $\mathrm{Cu}$ and $\mathrm{NiO}$. Respectively, $\mathrm{R}_{1}$ and $\mathrm{R}_{2}$ correspond to their charge-transfer resistance at different overpotentials. The separated $\mathrm{Q}_{1}$ and $\mathrm{Q}_{2}$ indicate that $\mathrm{Cu}$ and $\mathrm{NiO}$ play individual elements in the equivalent circuit diagram, wherein their contribution in the catalyzing process is standalone. This is an indicator of the absence of heterointerface between $\mathrm{NiO}$ and $\mathrm{Cu}$ in phy- $\mathrm{HO}_{\mathrm{M}}-\mathrm{NiO} / \mathrm{Cu}$, but deducing the existence of heterointerface in our $\mathrm{HO}_{\mathrm{M}}-\mathrm{NiO} / \mathrm{Cu}$. In addition, the value of $\mathrm{Q}_{1}$ and $\mathrm{Q}_{2}$ is very small, limiting HER activity (Figure S2f). More importantly, in the case of phy- $\mathrm{HO}_{\mathrm{M}}-\mathrm{NiO} / \mathrm{Cu}$, no component of $\mathrm{C}_{\varphi}$ was fitted out, verifying that charge (majority is $\mathrm{H}^{*}$ ) adsorption behavior on the catalyst 
surface is absent, and no hydrogen spillover mechanism proceed. It is credible that heterointerface can positively result in hydrogen spillover and improve the whole of HER kinetics. 
Table S11. The preparation cost of the electrode per unit area (USD $/ \mathrm{cm}^{2}$ ).

\begin{tabular}{cccccc} 
Source material & Data Source & $\begin{array}{c}\text { Unit } \\
\text { Price (USD) }\end{array}$ & $\begin{array}{c}\text { Used account } \\
\text { (unit) }\end{array}$ & $\begin{array}{c}\text { Cost } \\
\text { (USD) }\end{array}$ & $\begin{array}{c}\text { Sum } \\
\text { Cost(USD) }\end{array}$ \\
\hline $\begin{array}{c}\text { 20\%Pt/carbon } \\
\text { Nafion117 }\end{array}$ & Sigma-Aldrich.com & $125 / \mathrm{g}$ & $0.002 \mathrm{~g}$ & 0.25 & \\
Carbon Paper & Sigma-Aldrich.com & $157 / 25 \mathrm{~mL}$ & $0.02 \mathrm{~mL}$ & 0.1256 & $0.4856 / \mathrm{cm}^{2}$ \\
\hline $\begin{array}{c}\text { Ti( }\left(\mathrm{NO}_{3}\right)_{2} \cdot 6 \mathrm{H}_{2} \mathrm{O} \\
\text { Copper Foam }\end{array}$ & aladdin-e.com & $0.255 / \mathrm{g}$ & $0.007785 \mathrm{~g}$ & 0.001985 & \\
Electricity & alibaba.com & $58 /(20 \mathrm{~cm} * 30 \mathrm{~cm})$ & $1 \mathrm{~cm}^{2}$ & 0.09667 & $0.1914 / \mathrm{cm}^{2}$ \\
\hline
\end{tabular}

It is thus clear that our catalysis has great cost advantages.

\section{References}

1. Yu, L.; Zhou, H.; Sun, J.; Qin, F.; Yu, F.; Bao, J.; Yu, Y.; Chen, S.; Ren, Z., Cu Nanowires Shelled with NiFe Layered Double Hydroxide Nanosheets as Bifunctional Electrocatalysts for Overall Water Splitting. Energy Environ. Sci. 2017, 10 (8), 1820 1827.

2. Xu, Y. F.; Gao, M. R.; Zheng, Y. R.; Jiang, J.; Yu, S. H., Nickel/Nickel (II) Oxide Nanoparticles Anchored onto Cobalt (IV) Diselenide Nanobelts for the Electrochemical Production of Hydrogen. Angew. Chem. 2013, 52 (33), 8546-8550.

3. Li, J.; Liu, H.-X.; Gou, W.; Zhang, M.; Xia, Z.; Zhang, S.; Chang, C.-R.; Ma, Y.; Qu, Y., Ethylene-Glycol Ligand Environment Facilitates Highly Efficient Hydrogen Evolution of $\mathrm{Pt} / \mathrm{CoP}$ through Proton Concentration and Hydrogen Spillover. Energy Environ. Sci. 2019, 12 (7), 2298-2304.

4. Kuang, Y.; Kenney, M. J.; Meng, Y.; Hung, W.-H.; Liu, Y.; Huang, J. E.; Prasanna, R.; Li, P.; Li, Y.; Wang, L., Solar-Driven, Highly Sustained Splitting of Seawater into Hydrogen and Oxygen Fuels. Proc. Natl. Acad. Sci. 2019, 116 (14), 6624-6629.

5. Perdew, J. P.; Burke, K.; Ernzerhof, M., Generalized Gradient Approximation Made Simple. Phys. Rev. Lett. 1996, 77 (18), 3865. 
6. Monkhorst, H. J.; Pack, J. D. J. P. r. B., Special Points for Brillouin-Zone Integrations. Phys. Rev. B 1976, 13 (12), 5188.

7. Dudarev, S.; Botton, G.; Savrasov, S.; Humphreys, C.; Sutton, A. J. P. R. B., Electron-Energy-Loss Spectra and the Structural Stability of Nickel Oxide: An LSDA+ U Study. Phys. Rev. B 1998, 57 (3), 1505.

8. Nørskov, J. K.; Bligaard, T.; Logadottir, A.; Kitchin, J.; Chen, J. G.; Pandelov, S.; Stimming, U., Trends in the Exchange Current for Hydrogen Evolution. J. Electrochem. Soc. 2005, 152 (3), J23-J26.

9. Henkelman, G.; Uberuaga, B. P.; Jónsson, H., A Climbing Image Nudged Elastic Band Method for Finding Saddle Points and Minimum Energy Paths. The Journal of Chemical Physics 2000, 113 (22), 9901-9904.

10. Henkelman, G.; Jónsson, H., Improved Tangent Estimate in the Nudged Elastic Band Method for Finding Minimum Energy Paths and Saddle Points. J. Chem. Phys. 2000, 113 (22), 9978-9985.

11. Zhang, M.; de Respinis, M.; Frei, H., Time-Resolved Observations of Water Oxidation Intermediates on A Cobalt Oxide Nanoparticle Catalyst. Nat. Chem. 2014, 6 (4), 362-367.

12. Trze Niewski, B. J.; Diaz-Morales, O.; Vermaas, D. A.; Longo, A.; Bras, W.; Koper, M. T. M.; Smith, W. A., In Situ Observation of Active Oxygen Species in FeContaining Ni-Based Oxygen Evolution Catalysts: The Effect of $\mathrm{pH}$ on Electrochemical Activity. J. Am. Chem. Soc. 2015, 137 (48), 15112-15121.

13. Huang, Z.-F.; Song, J.; Du, Y.; Xi, S.; Dou, S.; Nsanzimana, J. M. V.; Wang, C.; 
Xu, Z. J.; Wang, X., Chemical and Structural Origin of Lattice Oxygen Oxidation in Co-Zn Oxyhydroxide Oxygen Evolution Electrocatalysts. Nat. Energy 2019, 4 (4), 329 338.

14. Yang, C.; Fontaine, O.; Tarascon, J. M.; Grimaud, A., Chemical Recognition of Active Oxygen Species on the Surface of Oxygen Evolution Reaction Electrocatalysts. Angew. Chem. 2017, 129 (30), 8778-8782.

15. Cai W, Chen R, Yang H, Tao H B, Gao J, Liu W, Liu S, Hung S, Liu B., Amorphous versus Crystalline in Water Oxidation Catalysis: A Case Study of NiFe Alloy[J]. Nano Letters, 2020, 20(6): 4278-4285.

16.Tao H B, Xu Y, Huang X, Chen J, Pei L, Zhang J, Chen J G, Liu B., A General Method to Probe Oxygen Evolution Intermediates at Operating Conditions[J]. Joule, 2019, 3(6): 1498-1509.

17. Subbaraman R, Tripkovic D, Chang K C, Strmcnik D, Paulikas A P, Hitunsit P, Chan M, Greeley J, Stamenkovic V, Markovic N M., Trends in Activity for the Water Electrolyser Reactions on $3 \mathrm{dM}(\mathrm{Ni}, \mathrm{Co}, \mathrm{Fe}, \mathrm{Mn}) \mathrm{Hydr}(\mathrm{oxy})$ oxide Catalysts[J]. Nat. Mater., 2012, 11(6): 550-557.

18. Bai, B. E. C., Lijun, Determination of Adsorption of OPDH Species in the Cathodic Hydrogen Evolution Reaction at Pt in Relation to Electrocatalysis. J. Electroanal. Chem. Interfacial Electrochem. 1986, 198 (1), 149-175.

19. Bai, L.; Harrington, D.; Conway, B., Behavior of Overpotential-Deposited Species in Faradaic Reactions-II. AC Impedance Measurements on $\mathrm{H}_{2}$ Evolution Kinetics at Activated and Uunactivated Pt Cathodes. Electrochim. Acta 1987, 32 (12), 1713-1731. 
20. Šimpraga, R.; Tremiliosi-Filho, G.; Qian, S.; Conway, B., In Situ Determination of the 'Real Are Factor' in $\mathrm{H}_{2}$ Evolution Electrocatalysis at Porous $\mathrm{NiFe}$ Composite Electrodes. J. Electroanal. Chem. 1997, 424 (1-2), 141-151.

21. Nørskov, J. K.; Studt, F.; Abild-Pedersen, F.; Bligaard, T., Fundamental Concepts in Heterogeneous Catalysis, $1^{\text {st }}$ Edition; John Wiley \& Sons, Inc.: Hoboken, NJ, 2014; Chapter 3.4, p40-44. 